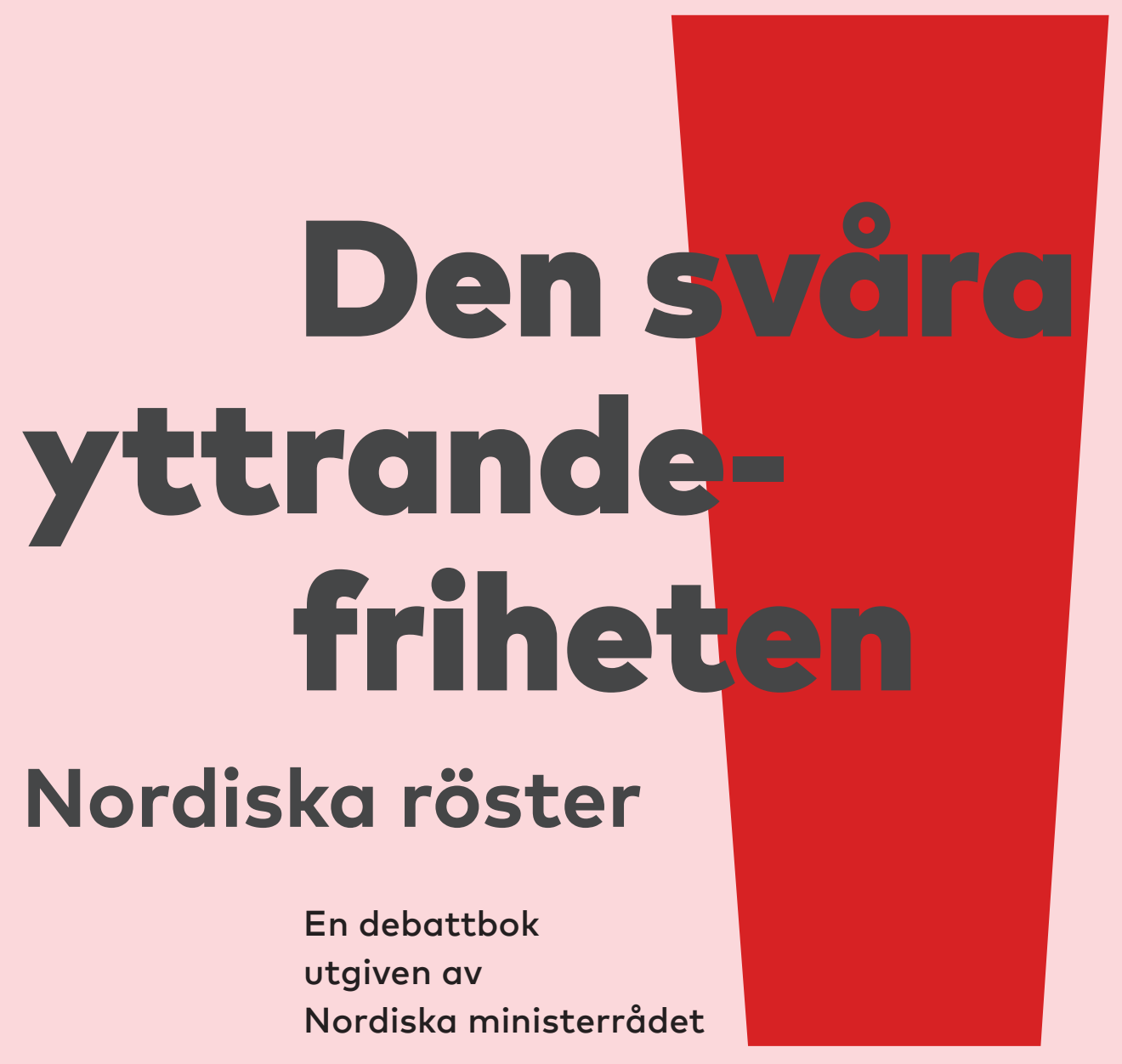

(1) Nordiska ministerrådet

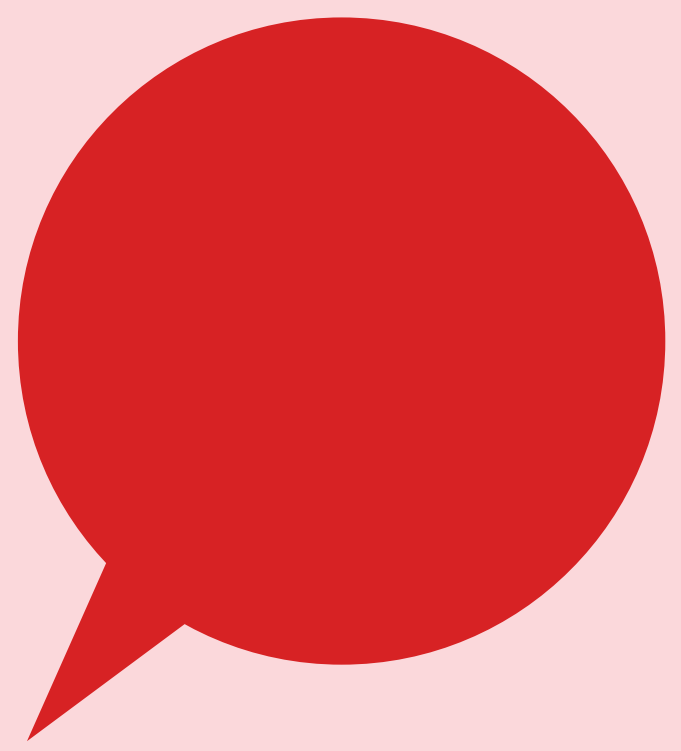




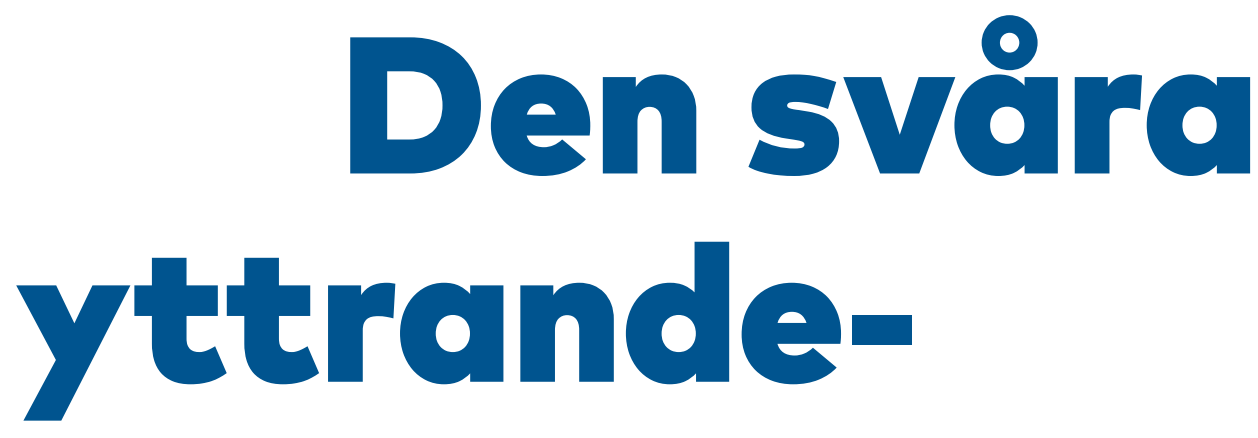

friheten

Nordiska röster

En debattbok utgiven av

Nordiska ministerrådet 


\section{Den svåra yttrandefriheten \\ Nordiska röster}

Redaktion: Per Lundgren, Mogens Blicher Bjerregård och Ole Rode Jensen

Boken har utarbetats av Nordiskt Journalistcenter på uppdrag av Nordiska ministerrådet.

ANP 2017:727

ISBN 978-92-893-4967-3 (PRINT)

ISBN 978-92-893-4968-O (PDF)

ISBN 978-92-893-4969-7 (EPUB)

http://dx.doi.org/10.6027/ANP2017-727

(C) Författarna och Nordiska ministerrådet 2017

Layout: Pernille Sys Hansen/Damp Design

Tryck: Rosendahls

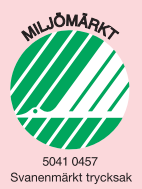

Printed in Denmark

Nordiska Ministerrådet vill med denna bok främja en mångfald av berättelser från hela Norden kring yttrandefrihet. Skribenternas åsikter är deras egna och representerar inte nödvändigtvis Nordiska Ministerrådets hållning.

\section{Det nordiska samarbetet}

Det nordiska samarbetet är ett av världens mest omfattande regionala samarbeten. Det omfattar Danmark, Finland, Island, Norge och Sverige samt Färöarna, Grönland och Åland.

Det nordiska samarbetet är politiskt, ekonomiskt och kulturellt förankrat och en viktig del av europeiskt och internationellt samarbete. Den nordiska gemenskapen arbetar för ett starkt Norden i ett starkt Europa.

Det nordiska samarbetet vill styrka nordiska och regionala intressen och värderingar i en global omvärld. Gemensamma värderingar länderna emellan bidrar till att stärka Nordens ställning som en av världens mest innovativa och konkurrenskraftiga regioner.

\section{Nordiska ministerrådet \\ Ved Stranden 18 \\ DK-1061 København K \\ www.norden.org}

Ladda ner nordiska publikationer: www.norden.org/nordpub 
4 Förord

8 Den sorte varevogn

Af Liljan Weihe (Færøerne)

16 Utan jämställdhet ingen yttrandefrihet Av Maria Edström (Sverige)

24 "Skrevet til den unge mand nævnt i skriftet"

Af Knud Steffen Nielsen (Danmark)

32 Press freedom in the Nordics - but with one eye By Ali Alabdallah (Sweden)

40 Frie medier er i alles interesse - også magthavernes

Af Poul Krarup (Grønland)

48 Sámi media adds value to Nordic societies

By Pirita Näkkäläjärvi (Sápmi, Finland)

56 Undersökande journalistik allt viktigare i en global värld

Av Axel Rappe (Finland)

64 Folk må oppfatte at journalistikk gjør en forskjell

Av Kjersti Løken Stavrum (Norge)

72 Visa hänsyn - publicera namn

Av Astrid Olhagen (Åland)

80 Trolde stopper unges politiske arbejde

Af Emma Holten (Danmark)

88 Ut av skammen

Strategier mot netthets

Av Aina Landsverk Hagen (Norge)

96 Algoritmen blir redaktör

Av Per Strömbäck (Sverige)

104 Glöm fakta, tjäna pengar

Av Heikki Jokinen (Finland)

112 The challenge in an era of misinformation and disinformation

Articles in Danish, By Elfa Ýr Gylfadóttir (Iceland)

Norwegian, and

Swedish

Citater

have English

Dagfinn Høybråten (Norge), generalsekretær i

abstracts

Nordisk ministerråd 


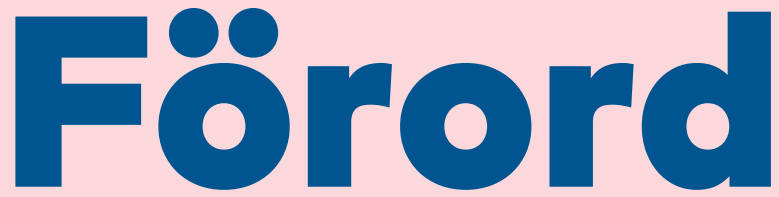

Nordiska medier i de nordiska demokratierna, är titeln på ett initiativ från Nordiska ministerrådet, omkring effekter av digitalisering och globalisering i de nordiska länderna samt Grönland, Färöarna och Åland. Det är ett initiativ för att stödja utvecklandet av innovativa redskap som stärker vår kultur med fokus på nordiskt och internationellt samarbete, för att skapa hållbar medieutveckling.

Detta initiativ riktar sig mot mekanismer som begränsar och hindrar nya generationer att delta i samhälls- och politiska diskussioner och debatter, mot mekanismer som försvårar för öppna samtal, faktabaserade världsbilder och demokratiska processer.
Steg för steg växer kunskap och insikt fram genom bokens 14 nordiska författare, ett rundabordssamtal med internationella experter vid UNESCOs World Press Freedom Days, vid öppna debatter i nordiska folkmöten, genom seminarieanalyser med medieexperter och vid toppmöten med politiker, medieledare och medieägare i Norden.

\section{Med samtalen bygger}

\section{vi samfundet}

Skriv en opdatering med lidt kant på Facebook eller et andet socialt medie og bliv overfuset. Især yngre kvinder risikerer at blive lagt for had, hvilket der er alt for mange eksempler på, ja bare ét eksempel er et for meget. Skal vi give igen af samme skuffe, eller skal vi tie stille? Spørgsmålene stiller sig i kø, og 
nogle af dem er med her i bogen, hvor der også er svar, men ingen facitliste.

Kun ved at ytre os til hinanden i tale, skrift eller på billeder forstår vi hinanden. Det handler både om samtalen og om ytringsfriheden, som ikke kan gradbøjes. Alligevel er netop samtalen og ytringsfriheden alvorlig udfordret af nye tendenser i medierne, hvor både hate speech og det senest tilkomne fake news udgør en trussel mod den troværdighed, der altid har været omkring nordiske medier.

I denne bog fortæller forfattere, journalister og forskere fra alle egne af Norden, hvordan de oplever udviklingen set med en nordisk tilgang fra netop deres udkigspost. Vi skal nemlig med gennem dialog fortsætte med at kunne løse konflikter, udvikle demokratier og sikre, at vi også i fremtiden har samfund, hvor der er plads til alle.

Læs, lyt, se og vær med til at samtale og bidrage til at udvikle frie samfund med respekt for menneskerettighederne. I denne bog er der inspiration at hente.

Per Lundgren, seniorrådgivare Kultur och medier Nordiska ministerrådet

Mogens Blicher Bjerregård, president, European Federation of Journalists

Ole Rode Jensen, Nordisk Journalistcenter 


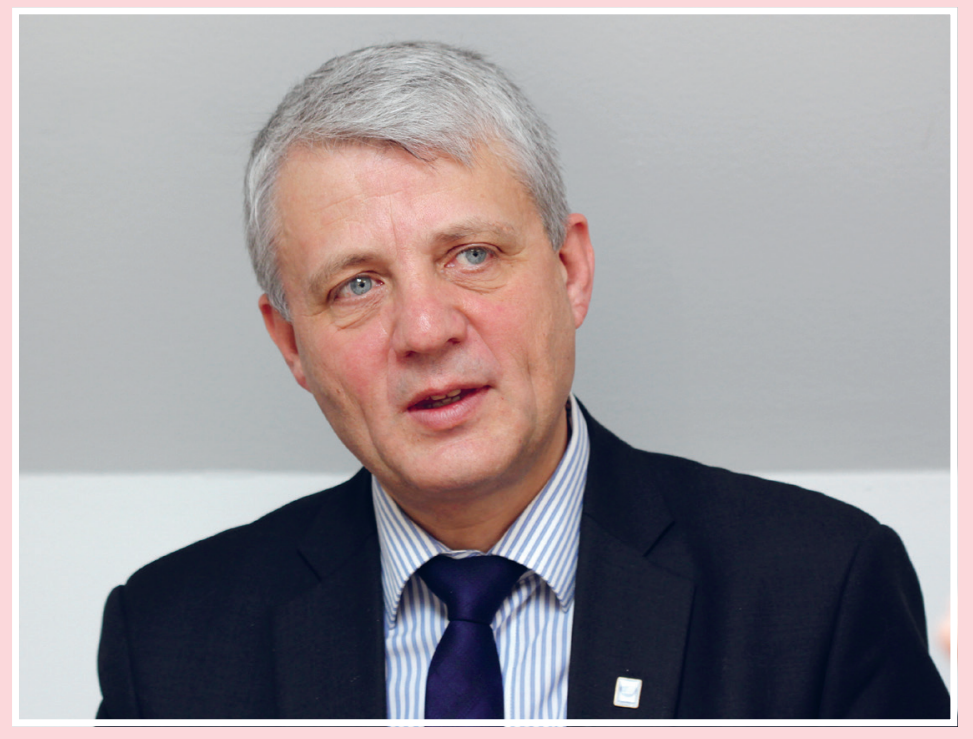

"The increase of media outlets has made it easy for everybody to take part in the debate. Unfortunately it has also created more hatred and in particular towards young females. Thus, our Nordic tradition for press ethics and gender is an important signal for other countries." 
"Framkomsten av mange nye medier har gjort det enkelt for alle å delta i debatten, men har dessverre også medvirket til en skremmende utvikling av hatefulle ytringer som spesielt rammer kvinner. Derfor er det viktig at de nordiske tradisjonene for presseetikk holdes i hevd og blir tatt alvorlig på alle medieplattformer. Og med likestilling som prinsipp kan vi vise omverdenen veien!"

Dagfinn Høybråten (Norge), generalsekretær i Nordisk ministerråd 

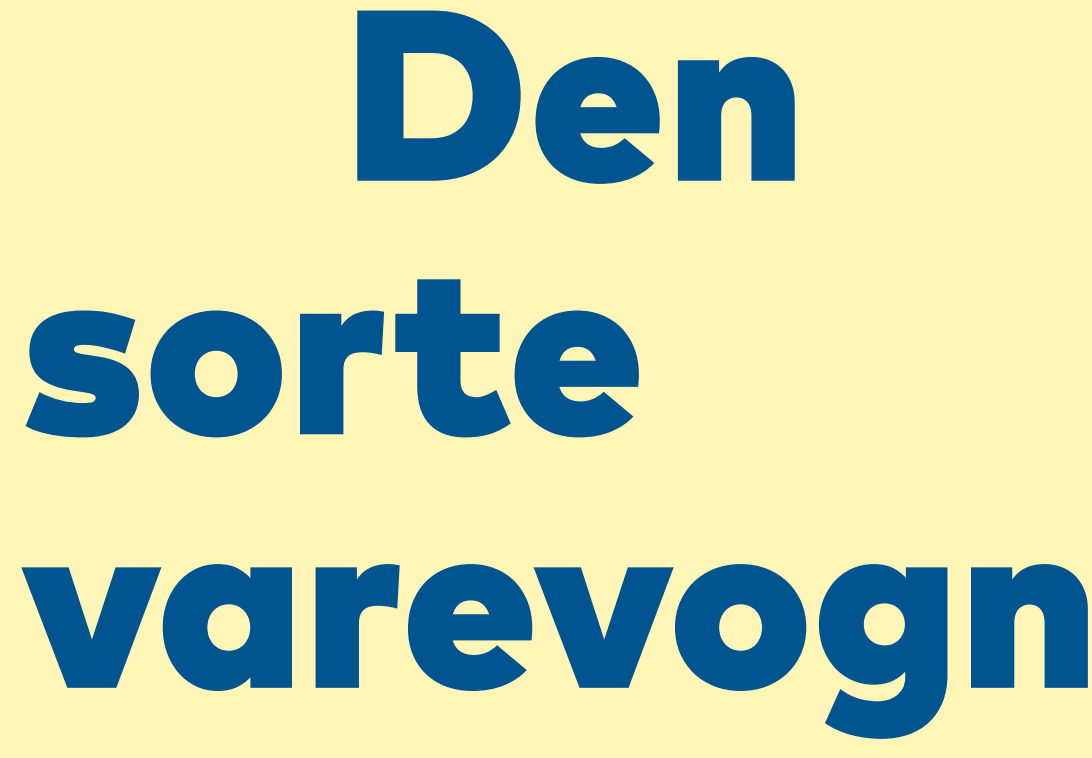

Jeg har senere fòet andre ulækre og fantasifulde trusler. Den seneste var en mand, der fantaserede om at fæste fiskekroge i mine skamlæber for siden at hænge mig op til offentlig beskuelse i disse kroge ...

\section{Af Liljan Weihe (Færøerne)}


Liljan Weihe.

Foto: Mogens Blicher Bjerregård. Illustration: Ole Rode Jensen.

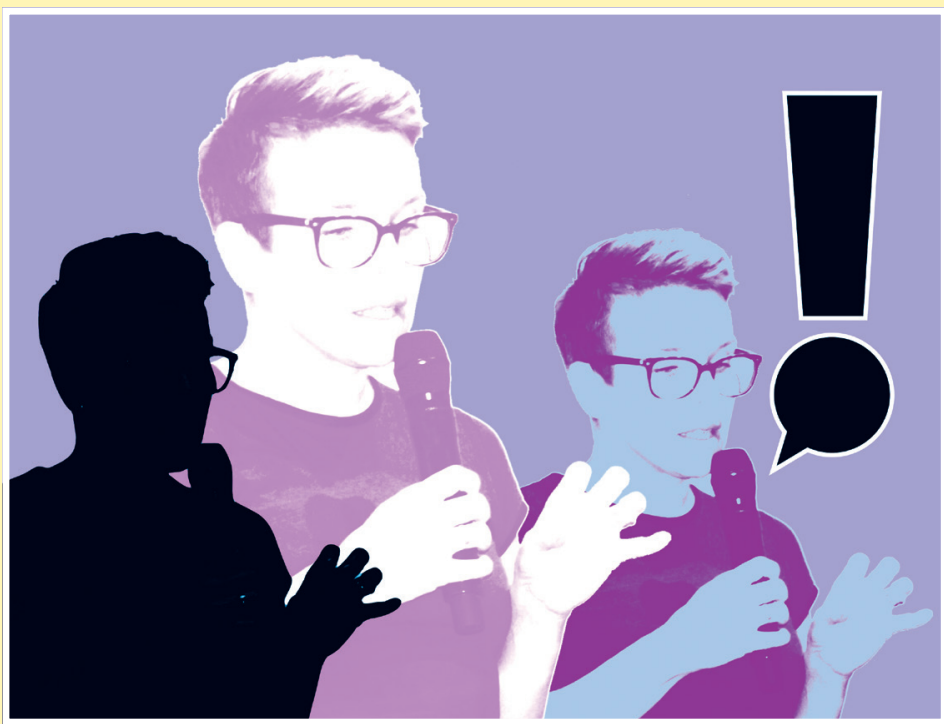

For færøske Liljan Weihe havde ytringsfriheden en meget konkret pris: En opslidende injuriesag for at passe sit arbejde og personlige, sexistiske trusler på Facebook. Men vi skal hverken som journalister eller borgere finde os i trusler, siger hun i dette barske indlæg i debatten om den svære ytringsfrihed.
27. april klokken 20.00. Jeg er lige kommet hjem fra en lang arbejdsdag. Hjem til min mand og mine to sønner, som jeg lige når at kysse godnat. Sminken ligger som en tyk maske på mit ansigt. Jeg har lige været vært på tv-nyhederne for første gang i lang tid.

Telefonen ringer

"Hallo?"

"Ja, hej. Jeg synes fandeme, at du skal anmelde de tosser til politiet. Nu er det sgu blevet for meget!", siger min mandlige kollega og personlige ven.

"Hvad?", siger jeg. Jeg aner ikke, hvad han taler om.

"Voldtægtstruslen på Facebook!", siger han oprevet.

"På Facebook? Jeg har ikke set nogen trussel ...?" 
"Jeg sender dig et screenshot. Men det her er ikke ok!"

"Ok. Hej."

Min mand kigger på mig. Spørger mig, hvad der sker. Jeg er omtumlet af samtalen, men prøver at forklare ham, hvad samtalen handlede om. Min mand, som ellers aldrig er opfarende, bliver rasende. Jeg er chokeret, men forholder mig mere roligt og venter på at modtage billederne.

Forud for voldtægtstruslen ligger en lang, drænende - og endnu ikke afsluttet - retssag om injurier.

\section{Tilbage til 9o'erne}

Historien starter i begyndelsen af 90'erne. Jørgen Niclasen, en ung færøsk politiker for Det færøske folkeparti, Fólkaflokkurin, er netop blevet sat i spidsen for familieforetagendet - et byggemarked i hans hjembygd på øerne. Virksomheden er i finansielle problemer, lige som de fleste andre virksomheder på øerne, da Færøerne oplevede en dyb finanskrise i 9o'erne. Familievirksomheden holdt derfor op med at betale told af importerede varer i et forsøg på at overleve og opbyggede en stor, vautoriseret toldgæld.

Samtidig var Jørgen Niclasen medlem af Lagtinget og medlem af et udvalg, der arbejdede med at revidere de færøske toldregler. Toldregler, som han ignorerede som direktør i familievirksomheden. Historien har været kendt i mange år på Færøerne, og færøske journalister har forsøgt at få aktindsigt i dokumenterne i sagen i næsten tyve år. Men uden held.

Den væsentligste årsag er, at myndighederne på Færøerne ikke var særlig hjælpsomme, tværtimod forhindrede myndighederne journalisterne i at få aktindsigt i sagen. I efteråret 2013 lykkedes det endelig en journalist at få tilstrækkelig indsigt i par dokumenter, der dokumenterede den vautoriserede toldgæld. På det tidspunkt var Jørgen Niclasen, den unge politikerspire, blevet partiformand i Fólkaflokkurin. Han var også finansminister og dermed højeste told-og skattemyndighed på Færøerne.

Forordninger, som han tyve år tidligere systematisk havde brudt ved at sælge udeklarerede varer, skulle han nu selv sikre blev overholdt. Selvfølgelig havde historien offentlig interesse. Og vi, Færøernes tv og radio, Kringvarp Føroya, var forpligtet til at fortælle den.

\section{Trusler om fængsel}

Historien blev offentliggjort på en nyhedsportal i december 2013, og vi fulgte op på historien med det samme.

Journalisten, der offentliggjorde historien, bad selvfølgelig finansministeren kommentere historien inden den blev offentliggjort. Ministeren gav ham aldrig nogen kommentar, men fik sin advokat til at ringe til journalisten. Advokaten truede journalisten med fængsel, hvis han offentliggjorde historien. 


\section{ID Det var fuldstændig klart for mig, at vi ikke kun havde ret til at fortælle historien, vi var også forpligtede til det.}

De følgende måneder blev vi truet med fængsel fire eller fem gange, før finansministeren besluttede at sagsøge os for injurier og prøve sagen i retten.

\section{Få og små}

Jeg var ikke bekymret. Det var fuldstændig klart for mig, at vi ikke kun havde ret til at fortælle historien, vi var også forpligtede til det. Og selv om historien om toldsnyd var gammel, var den stadig væsentlig at fortælle. Måske endda mere væsentlig. Politikerspiren, der havde snydt i told, var nu en af de mest magtfulde personer på Færøerne og som finansminister den højeste myndighed i toldsager.

Men dommeren i Byretten delte ikke min mening om sagen. Han fandt os skyldige i injurier, og vi blev idømt dagbøder, erstatning til Jørgen Niclasen og skulle betale hans sagsomkostninger. Sammenlagt kom beløbet op på flere hundrede tusind kroner.

Dommeren erkendte, at Jørgen Niclasen havde opbygget en stor del af virksomhedens vautoriseret toldgæld, men fandt alligevel nyhedsdækningen injurierende. Vi tabte i Byretten med den begrundelse, at Færøerne er et lille samfund, og at mediedækning som vores ville afholde andre fra at stille op til politiske valg. Altså, skulle vi på Færøerne ikke forlange samme moralske standard af vores politikere som i andre lande, fordi vi er små og få.

\section{Oprejsning}

Det ville vi selvfølgelig ikke finde os i. Hverken i at tabe, og slet ikke med den begrundelse, at der skal tages særlige hensyn til magthavere i små samfund, da dommen derved i fremtiden ville indsnævre presse- og ytringsfriheden på Færøerne.

Vi ankede straks afgørelsen til Landsretten - og de tre landsretsdommere underkendte dommen fra Byretten og frikendte os for injurier. Dommerne understregede i dommen, at vi ikke blot havde ret til at fortælle historien om den uautoriserede toldgæld, men vi havde også i vores mediedækning dokumenteret toldsnyd, der var sket for mere end tyve år siden. 
Jørgen Niclasen appellerede landsretsdommen til Højesteret, men sagen blev afvist.

\section{Konsekvenser for journalistikken}

Det var en kæmpe lettelse endelig at kunne lægge injuriesagen bag os. Og selvfølgelig er jeg glad for, at vi blev frikendt. Dommen i Landsretten stadfæster vigtigheden af en fri presse. Den styrker vores position som vagthund. Men selv om vi blev frikendt, har der været konsekvenser.

Vi var tre medarbejdere hos Kringvarp Føroya, der blev sagsøgt. Direktøren, jeg selv, som er nyhedschef, og en journalist. Kringvarp Føroya har en bestyrelse, der dels fungerer som mellemled mellem den politiske myndighed, Kulturministeren, og public service-mediet, og så skal bestyrelsen også godkende den overordnede prioritering i programfladen og de årlige budgetter. Bestyrelsen er ansættelsesmyndighed hos direktøren, mens direktøren ansætter medarbejdere, også mellemledere som mig selv.

Men da bestyrelsen til dels er direkte valgt af de politiske partier, har der været politisk pres på bestyrelsen i forbindelse med injuriesagen. Pres som desværre gav genlyd langt nede i systemet, hos nyhedsredaktionerne.

Jeg blev som nyhedschef sat i skammekrog, da dommen faldt i Byretten. Nyhedsafdelingen hos Kringvarp Føroya er lille, så jeg indgår også i selve nyheds- produktionen. Men efter dommen blev jeg taget af skærmen, jeg måtte ikke længere være nyhedsvært og mit navn og min stemme skulle hverken ses eller høres nogen steder på programfladen. Det samme var gældende for nyhedsjournalisten. Han blev sendt på ferie.

Flere mente, at vi burde fyres eller i det mindste suspenderes. Derudover var der mange, der mente, at vi personligt skulle hæfte for dommen. Vi skulle ikke alene miste vores arbejde, vi skulle også personligt punge ud med hundredetusindvis af kroner for at lave vores arbejde.

\section{Demokrati}

Injuriesager mod journalister i de øvrige nordiske lande får ikke samme opmærksomhed som på Færøerne. Umiddelbart før vores injuriesag, var der nogle injuriesager i Danmark. To journalister hos Danmarks Radio blev sagsøgt for injurier og tabte. Men selvom de tabte både i Byretten og senere i Landsretten, fik det ikke arbejdsmæssige eller økonomiske konsekvenser for dem. Ingen snak om at få dem fyret. Ingen skammekrog. Faktisk blev de begge mere eller mindre forfremmet. Den ene blev vært på TV Avisen, den anden fik sit eget tv-magasin.

Medier og journalister har en stærkere position i Danmark end på Færøerne. Det færøske demokrati er stadig meget ungt, og vi har ikke så lang tradition for kritisk journalistik, 
som i de øvrige nordiske lande. Det gør færøske journalister langt mere sårbare, men ikke desto mindre vores demokratiske opgave det større.

\section{Selvcensur}

At sagsøge os for injurier var et forsøg på at lukke munden på os - og jeg er ked af at indrømme, at det virkede efter hensigten. Injuriesagen har forårsaget en form for selvcensur i medierne. Journalister er bange for at blive sagsøgt for injurier - selv om de har en veldokumenteret historie. lkke fordi de er bange for at blive dømt, men fordi en retssag i sig selv er en trussel mod deres troværdighed som journalister, og de har set, hvordan en retssag kan have konsekvenser - både professionelt og personligt - for andre journalister.

Hate speech og trusler på sociale medier er med til at true ytringsfriheden.

Derfor er frygt er det bedste våben mod ytringsfriheden. I vores tilfælde forårsager frygt selvcensur. Og selvcensur er ukontrolleret. Den har ingen klare grænser.

\section{Personlige trusler}

Efter tre måneder i skyggen fik jeg lov til at komme på skærmen igen. Voldtægtstruslen kom efter min første værtsvagt efter dommen i Byretten.

En ung mand, som jeg aldrig har mødt, var så irriteret over et interview jeg havde med sundhedsministeren i tv-nyhederne den aften, at han syntes jeg fortjente at blive gruppevoldtaget og arrangerede det på Facebook.

Statusopdatering XXX: Liljan Weihe er irriterende at høre på.

YYY: Hørt!

ZZZ: Jeg ved, hvor hun bor!

XXX: Hun er i Kringvarp Føroya lige nu. Jeg tænder min sorte gangsterbus (rape van) så tager vi alle sammen afsted. Hvem er med?

ZZZ: Jeg er med!

XXX: Hun er republikaner så det basker!

Bum. Den sad.

\section{Sexisme}

Det undrer mig, at en ung mand, som selv har en kæreste, kan være så nedladende mod kvinder. At han overhovedet kan tænke tanken, at kvinder har fortjent at blive voldtaget, fordi han personligt ikke bryder sig om deres arbejde. Det undrer mig, at han ikke tænker på sin kæreste, sin mor og andre kvinder i hans nærmeste omgangskreds. Det er jo ikke kun nedladende mod mig, men mod alle kvinder - også hans nærmeste. Hvordan kan en kvinde nogensinde gøre sig fortjent til at blive frihedsberøvet og seksuelt misbrugt?

At andre mænd uden videre er med på idéen, er næsten mere ufatteligt. Den anden mand, der ville med i voldtægtsbussen, var på det her tidspunkt skoleleder i en lokal folkeskole. En 


\section{Tanken om at mænd fantaserer om at voldtage mig, gjorde, at jeg følte mig beskidt ... Jeg har siden fået andre ulækre og fantasifulde trusler.}

ansvarsperson og et forbillede for børn og unge.

\section{Frygt}

Truslen skal ikke tages alvorligt, siger de. Det var en joke. Har du ingen humor, kvinde? Nej, jeg kan ikke se det sjove i en voldtægtstrussel. Det kan godt være, at truslen ikke skal tages bogstaveligt. Det kan godt være, at de blot ønskede at nedgøre mig på de sociale medier. Men voldtægtstruslen er italesat. Den har sat tanker i gang hos mig og måske også hos andre.

Jeg har altid betragtet mig selv som en selvsikker, stærk og vafhængig kvinde. Men truslerne skræmte mig, gjorde at jeg følte mig svag og usikker. Jeg begyndte at bekymre mig om, hvilke signaler jeg sendte ud til mænd. Om jeg på en eller anden måde selv havde fremprovokeret voldtægtstruslen. Og selv om disse to mænd sidenhen har sendt mig personlige undskyldninger på Facebook, bekymrer det mig, at der kan være andre forstyrrede mænd derude, som ikke kan se den tiltænkte humor i truslen, men i stedet bliver inspirerede af den. Jeg får stadig den følelse nogle gange, når jeg går hjem alene om natten.

\section{Skam}

En ting var frygten jeg følte. En anden følelse var skam. Jeg følte mig snavset. Jeg skammede mig, selv om jeg vidste, at jeg ikke var skyld i voldtægtstruslen. Men tanken om, at mænd fantaserer om at voldtage mig, gjorde, at jeg følte mig beskidt. Truslen gjorde mig upersonlig. Den gjorde mig til et objekt for mænd at misbruge seksuelt. Det er en meget ubehagelig følelse.

Jeg har siden fået andre ulækre og fantasifulde trusler. Den seneste var en mand, der fantaserede om at fæste fiskekroge i mine skamlæber for siden at hænge mig op til offentlig beskuelse i disse kroge, fordi vedkommende ikke brød sig om mit journalistiske arbejde. Da jeg læste opdateringen på Facebook blev jeg fysisk dårligt tilpas. Jeg fik kvalme og hovedpine. Jeg kunne ikke falde i søvn og mistede koncentrationen. 


\section{Råb op!}

Ytringsfriheden er truet på så mange fronter. En måde at indsnævre ytringsfriheden er med trusler. Trusler skaber frygt og frygt gør os irrationelle og skader journalistikken. Injuriesagen og voldtægtstruslen er ikke direkte forbundne, men de havde samme formål: at lukke munden på os journalister. Men vi skal hverken som journalister eller borgere finde os i trusler. Vi skal italesætte dem og gøre frygten til skamme. Vi skal råbe op og gøre det vi er bedst til: Fortælle historier.

\section{The black van}

Liljan Weihe: Jeg har været nyhedschef hos Kringvarp Føroya, Færøernes tv og radio, de sidste fem år. Jeg har tidligere arbejdet for færøske og grønlandske medlemmer $i$ Folketinget og $i$ centraladministrationen på Færøerne. Jeg har været journalist på den færøske avis, Dimmalætting, og praktikant hos TV2 i Danmark. Efter at have studeret socialvidenskab og journalistik på Roskilde Universitetscenter, valgte jeg at flytte hjem til Færøerne for at hellige mig journalistikken.
By Liljan Weihe (Faroe Islands)

Liljan Weihe is a news editor at Kringvarp Føroya (Faroese TV and radio).

Someone I don't know wrote something negative about me on Facebook. The thread took a sudden turn and ended up with a rape threat.

Two men, one of which I later found out was the principal at a local school, started fantasising about going to the newsroom to pick me up and gang rape me in a black van. They believe that I deserved it because they did not like an interview I made that evening.

Prior to the threat, I had faced a long and exhausting libel case. The minister of Finance had sued me and other journalists for libel because we reported a story about him that he disapproved of.

Although the rape threat had no direct connection to the libel case, they bear one thing in common - that is to keep me silent with fear. Fear is one of the biggest threats against freedom of speech. It causes self-censorship, which is uncontrolled and has no clear boundaries. That is why fear is so powerful.

The only way to fight against these threats is to face the fear and keep on doing what we do best - telling the truth. 


\section{Utan}
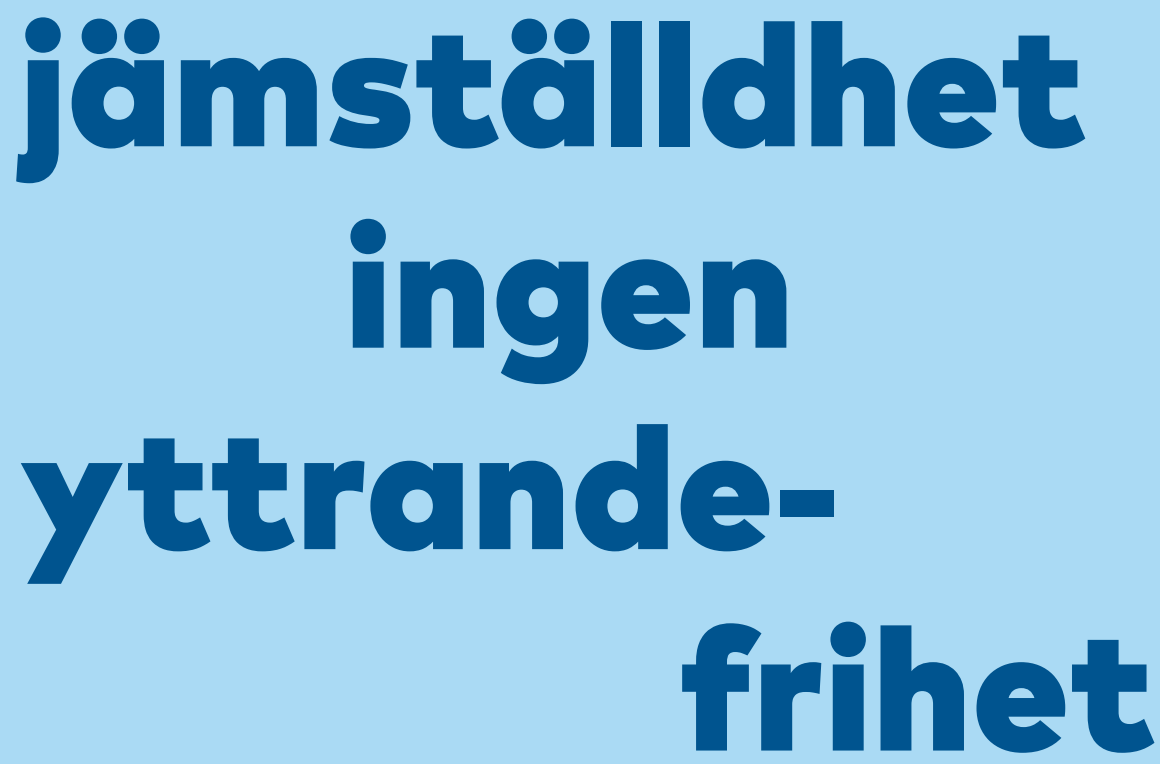

I det globala nyhetsflödet går det tre män på varje kvinna. Det är väl känt att män dominerar nyheterna och att kvinnor tilldelas färre och mer stereotypa roller i medierna.

Av Maria Edström (Sverige) 
Maria Edström. Foto: Johan Wingborg. Illustration: Ole Rode Jensen.

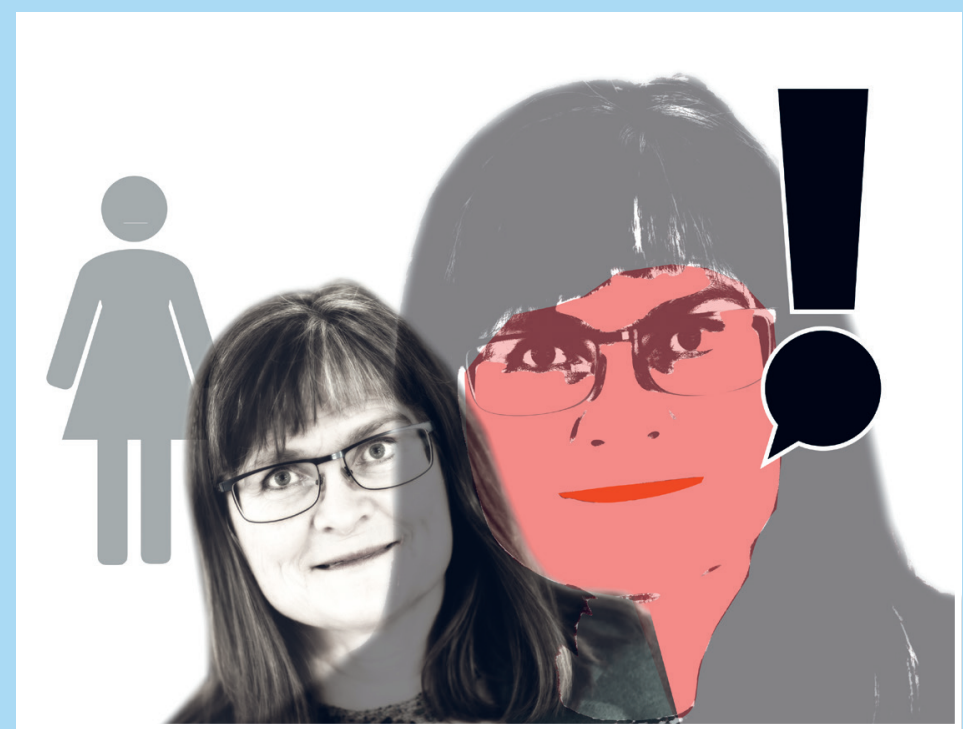

\section{Har vi yttrandefrihet om halva befolkningens åsikter, erfarenheter och kunskap negligeras eller tystas?}

Journalistiken förefaller vara är en rejäl bromskloss för jämställdhet och därmed också en för en hållbar utveckling. I det globala nyhetsflödet går det tre män på varje kvinna. I konfliktområden är det ännu värre, bara en av tio $i$ nyhetsflödet är kvinna.

Vill vi utrota fattigdom och hunger och se till att alla kan utnyttja sina mänskliga rättigheter behöver journalister öka sina kunskaper och vidga sina perspektiv, kanske till och med omvärdera sin nyhetsvärdering.

Har vi yttrandefrihet om halva befolkningens åsikter, erfarenheter och kunskap negligeras eller tystas? Det är väl känt att män dominerar nyheterna och att kvinnor tilldelas färre och mer stereotypa roller i medierna. Dessutom utsätts kvinnliga journalister oftare för sexistiskt hat och hot. Så kan vi inte ha det. Det är dags att utvidga yttrandefrihet att gälla även kvinnor.

Efter att i många år ha arbetat med medier och jämställdhet förvånas jag över hur sällan yttrandefrihet och jämställdhet diskuteras vid samma bord. Det är som om frågorna hålls isär, trots att de båda förutsätter varandra. För att vi ska ha en yttrandefrihet värd 
namnet måste vi ställa högre krav på vem som kommer tals, inte minst inom journalistiken.

\section{Journalister måste ha koll på konventioner}

Det finns tre viktiga dokument att luta sig som jag önskar att alla journalister, redaktionschefer och medieägare hade koll på:

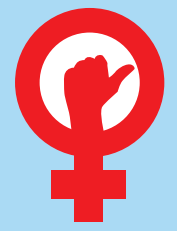

\section{FN:s Kvinnokonvention}

Det första dokumentet är FN:s Kvinnokonvention, CEDAW (Convention on the Elimination of All Forms of Discrimination against Women). Kvinnokonvention från 1979 handlar om att kvinnor och män ska ha lika rättigheter.

Det är den näst mest undertecknade FN-konventionen (efter barnkonventionen) och är juridiskt bindande för de 188 stater som undertecknat och ratificerat konventionen. De ska garantera att kvinnor har samma rättigheter som män.

Självklart gäller det även möjligheten att vara en del av det offentliga samtal som medierna utgör. CEDAW slår också fast att stereotyper är ett hinder för jämställdhet och att fördomar ska avskaffas/modifieras (Artikel 5):

"States Parties shall take all appropriate measures: (a) To modify the social and cultural patterns of conduct of men and women, with a view to achieving the elimination of prejudices and customary and all other practices which are based on the idea of the inferiority or the superiority of either of the sexes or on stereotyped roles for men and women."

Här har medierna en viktig roll att spela, de kan skapa, befästa eller utmana stereotyper. Både ämnesval och rollfördelning kan bidra till underblåsa stereotyper. Nyheter handlar om att välja. Därför är det viktigt att journalister är medvetna vilka val de gör och hur deras enskilda nyheter/reportage landar.

Även ett djuplodande ambitiöst reportage kan bidra till att befästa och bevara traditionella könsroller genom att till exempel låta män vara experter och låta kvinnor stå för känslor, beskrivas som offer eller enbart uttala sig om privatsfären.

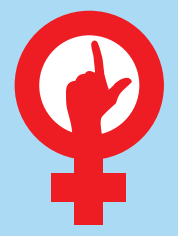

\section{Pekingplattformen}

Det andra dokumentet är handlingsplanen Pekingplattformen, Beijing Platform for Action, från 1995. Det viktiga med detta dokument är att medierna blev ett av de 12 områden där FN:s medlemsstater åtar sig att agera för att uppnå jämställdhet genom att öka kvinnors tillgång till medierna och främja balanserade och icke-stereotypa skildringar av kvinnor i medierna. 
Trots Pekingplattformen händer det för lite.

Samma år som Pekingplattformen antogs genomförde forskare och aktivister tillsammans en första global granskning av nyhetsflödet inom ramen för Global Media Monitoring Project (whomakesthenews.org).

Nyheter under en dags undersöktes då i 71 länder och resultatet var nedslående. Då, 1995 var andelen kvinnor i nyheterna 17 procent. Vid den senaste mätningen, 2015 då 114 länder deltog var andelen kvinnor 24 procent. Det blir alltså långsamt fler kvinnor i nyheterna, men det går långsamt. De senaste fem åren tycks ingenting ha hänt och även de nordiska länderna som rankas högt när det gäller jämställdhet har förbluffande få kvinnor i sina nyheter. Sverige ligger bland de bättre med omkring 30 procent kvinnor i de olika mätningarna.

\section{Brist på styrning}

Vi vet att jämställdheten utvecklas i världen, men det märks inte i nyhetsrapporteringen. Hur kan det vara så? En förklaring som journalister ofta ger är att det är män som styr och sitter på de flesta maktpositionerna, därför blir det mest män i nyheterna.

Men varför skulle inte nyheterna också kunna handla om dem som påverkas/drabbas av makten, då handlar det ju om både män och kvinnor. Dessutom är det ju allt fler kvinnor på maktpositioner i samhället så även det argumentet är ganska ihåligt.

En annan förklaring till bristen på kvinnor i medierna kan paradoxalt nog vara att staterna värnar yttrandefriheten, eller åtminstone överlåter åt medierna att sköta sig själva för att inte bli anklagade för censur och begränsa det fria ordet genom att kräva jämställda medier.

Man kan också argumentera för det motsatta, att om staterna ställde krav på medierna skulle det kunna bidra till att utvidga yttrandefriheten till att gälla både kvinnor och män.

\section{Brist på statistik}

Ett första steg skulle kunna vara att kräva att det finns jämförbar, könsuppdelad statistik på medieområdet. På global nivå är det få samhällsområden som uppvisar en sådan obefintlig statistik som mediebranschen, vi vet mycket lite om andelen kvinnor och män inom till exempel ägande, bolagsstyrelser, och höga chefer.

Enstaka studier har gjorts som visar att det tycks finnas ett glastak inom nyhetsmedierna. Många länder har numera en jämn fördelning av män och kvinnor på redaktionerna, men när det gäller toppchefer, ägare och styrelser är det fortfarande en stark mansdominans, ibland värre än i övriga näringslivet.

När det gäller medieinnehåll skulle man också kunna kräva att det finns 
jämförbar, könsuppdelad statistik.

Många redaktioner håller koll på vem som kommer till tals, men egen statistik blir sällan jämförbar med andras data. Det finns också exempel på redaktioner som inte har några problem att ha 50/50 män/kvinnor i sitt utbud. Genomgående för dessa redaktioner är att de har gjort jämställdhet och mångfald till en ledningsfråga och ser till att det finns dagliga rutiner för att hålla koll på vem som kommer till tals. I de nordiska länderna finns också en del företag som säljer algoritm-tjänster till nyhetsredaktionerna så att journalisterna (baserat på namn) i realtid kan se andelen kvinnor och män som förekommer i nyheterna på webben.

\section{Kvalitativ bedömning}

Nästa steg är att kräva att medierna levererar en kvalitativ bedömning av ovan nämnda statistik, vilka kvinnor och män förekommer och varför? Det behövs en ökad medvetenhet om varför vissa grupper inkluderas och andra exkluderas, beror det på journalisternas dåliga kontaktnät eller bristande kunskaper eller finns det helt enkelt ingen man att intervjua på aktuella området?

Yttrandefrihetsorganisationen Artikel 19 hade under många år en chef, Agnes Callamard som myntade begreppet "genusbaserad censur" för att beskriva redaktionella processer som tenderar till att uppvärdera vissa män och deras handlingar medan flertalet kvinnor och deras erfarenheter nervärderas.

\section{En fråga om överlevnad}

Redaktionella rutiner begränsar vem som kommer till tals på flera olika sätt. Är det mest unga, urbana människor är det kanske inte ett problem för en storstadstidning med ung målgrupp men om journalistiken ska uppfylla sin demokratiska uppgift som ett öppet forum för debatt behöver vi också ha medier som låter fler komma till tals.

När snart 25 procent av befolkningen är över 65 år behöver dessa personers erfarenheter också komma med, liksom att medierna tar på allvar att vi lever i ett mer multikulturellt samhälle. Kunskap om genus och jämställdhet är inte bara en demokratifråga utan en fråga om kommersiell överlevnad. Om journalistiken inte är nyttig och användbar både kvinnor och män riskerar medieföretagen att tappa hälften av sina användare. Det tredje argumentet är det publicistiska, det är så många bra nyheter/berättelser som journalister missar om de inte har kunskap om genus och jämställdhet så att de kan inkludera fler människors erfarenheter.

\section{Dags att diskutera stereotyper}

Det är kanske också dags att få en vettigare diskussion om hur stereotyper begränsar våra liv och till och med skadar oss, vare sig de möter oss som hätska utfall på nätet eller i det 
offentliga rummet. Stereotyper har en maktdimension, någon har formulerat dem och någon utsätts för dem. Genom att skriva på Kvinnokonventionen har staterna åtagit sig att lagstifta om det behövs för att uppnå jämställdhet och för att motverka könsstereotyper.

Som konsekvens har de flesta nordiska länder numera en lagstiftning mot sexistisk/könsdiskriminerande reklam. Intressant nog har Sverige inte velat lagstifta eftersom en begränsning av kommersiella meddelanden har ansetts som en inskränkning av den grundlagsskyddade yttrandefriheten, detta trots att reklam regleras i en egen lag, marknadsföringslagen.

Detta kan man tolka som ett typexempel på där jämställdhet ställs mot yttrandefrihet, som om de inte har med varandra att göra. Spanien har valt en annan väg, där har man lagstiftat mot könsdiskriminerande reklam eftersom man ser det som ett hinder för jämställdhet. Sommaren 2016 beslutade Londons borgmästare att stoppa sexistisk reklam i tunnelbanan och annan kollektivtrafik.

\section{Trots mångfald går det trögt}

En väg att gå är att verka för att många röster hörs, i många medier. Även här kan staterna ställa krav. De nordiska länderna har en tradition där staten har varit aktiv i att garantera en mångfald i debatten genom olika former av presstöd, filmstöd och kulturtidskriftsstöd liksom starka public service-medier med ett demokratiskt uppdrag. Ändå går det trögt. Samtidigt verkar det ändå som om när den offentliga delen av den nordiska mediebranschen får ett demokratiskt uppdrag så tar den det på allvar.

Forskning pekar på att public service-medierna tycks vara bättre på representation, både i organisationen och i utbudet. Svenska Filminstitutet har också visat att ett branschorgan på bara några år kan bidra till att göra en bransch mer jämställd så att både kvinnor och män finns framför och bakom kameran.

Vi lever i ett medialiserat samhälle som ställer krav på medborgarna att kunna förstå, använda och producera medier. Det behövs därför ett kunskapslyft kring medie- och informationskunnighet där källkritik och etik bör stå i centrum, men också mänskliga rättigheter. Yttrandefrihet innebär rättigheter men också skyldigheter. Därför är det viktigt med de "no hate speech"-kampanjer som pågår runt om i världen.

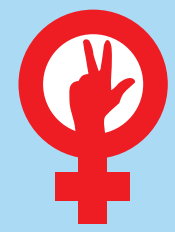

\section{Agenda 2030}

Utmaningen är att se helheten. Därför är det tredje viktiga dokumentet Agenda 2030, de globala hållbarhetsmålen som antogs 2015. Dokumentet innehåller 17 mål och 169 delmål som syftar till att engagera alla 
världens länder för rättvisare och mer hållbar värld.

I den nya globala agendan anses alla mål vara beroende av varandra, målen är integrerade och odelbara och balanserar de tre dimensionerna av hållbar utveckling: den ekonomiska, den sociala och den miljömässiga. Jämställdhet har ett eget mål (Mål 5) och i alla utvärderingar av Agenda 2030 ska man ta hänsyn till jämställdhetsaspekter.

Journalister skulle kunna koppla varje enskild nyhet till den globala agendan och därmed också inkludera fler kvinnor som källor och intervjupersoner. Men frågan är hur många journalister som läst på och har förmåga att granska, ifrågasätta och berätta om den globala agendan och dess utmaningar.

Varje land har sin egen kulturella och sociala historia och det finns inte en väg som passar alla för att nå ett jämställt samhälle. Samtidigt ska man inte underskatta vad generell lagstiftning för jämställdhet betyder för möjligheten för kvinnor och män att ha samma rättigheter, skyldigheter och möjligheter. Särbeskattning och delad föräldraledighet är exempel på lagstiftning som helt klart bidragit till att de nordiska länderna hamnar i topp på olika jämställdhetsindex.

Yttrandefrihet och mediefrihet är tyvärr ganska osynliga rättigheter i Agenda 2030 vilket säkert beror på olika politiska processer och kompromisser längst vägen. Själva ordet yttrandefrihet finns inte med i Agenda 2030 (inte pressfrihet eller mediefrihet heller) men man kan tolka in dessa viktiga demokratiska fri- och rättigheter som delar av generella rättigheter som det talas om i mål 16: att främja fredliga och inkluderande samhällen för hållbar utveckling, tillhandahålla tillgång till rättvisa för alla samt bygga upp effektiva, och inkluderande institutioner med ansvarsutkrävande på alla nivåer.

Det är dags att vidga yttrandefriheten, i medierna, i din hemstad, i ditt land och i världen.

\section{Både kvinnor och män måste}

kunna yttra sig och delta i 
Maria Edström är forskare och lärare vid institutionen för journalistik, medier och kommunikation vid Göteborgs universitet. Hennes specialområden är genus, jämställdhet och yttrandefrihet. Hon forskar även om hur äldre skildras $i$ medierna.

\section{Freedom of expression vs Gender equality -}

Time to step up

By Maria Edström (Sweden)

Maria Edström is a researcher and teacher at Gothenburg University, Department of Journalism, Media and Communication. Her research areas are freedom of expression, gender and equality.

Men are dominating the media. This is a problem for democracy. Because you cannot see the complete truth of the world if you only listen to half of the population.

If we want real freedom of expression, both men and women should have a voice in the public debate. Women should not be silenced due to sexualised hate speech.

More journalists need to be aware of the global commitment to gender equality and sustainability and start producing news through the life experience of women. Newsroom policy should take into account the Sustainable Development Goals, the Beijing platform for Action and CEDAW (The Convention on the Elimination of All Forms of Discriminations against Women).

Changes such as these will encourage more female participation in journalism, both in editorial management and in the news content. This is obvious but it will require willingness in order to include more voices in the media. The newsrooms that are successful have made gender equality and diversity a leadership issue. It is time to enlarge the meaning of freedom of expression by improving gender equality so that we can meet the global challenges. 

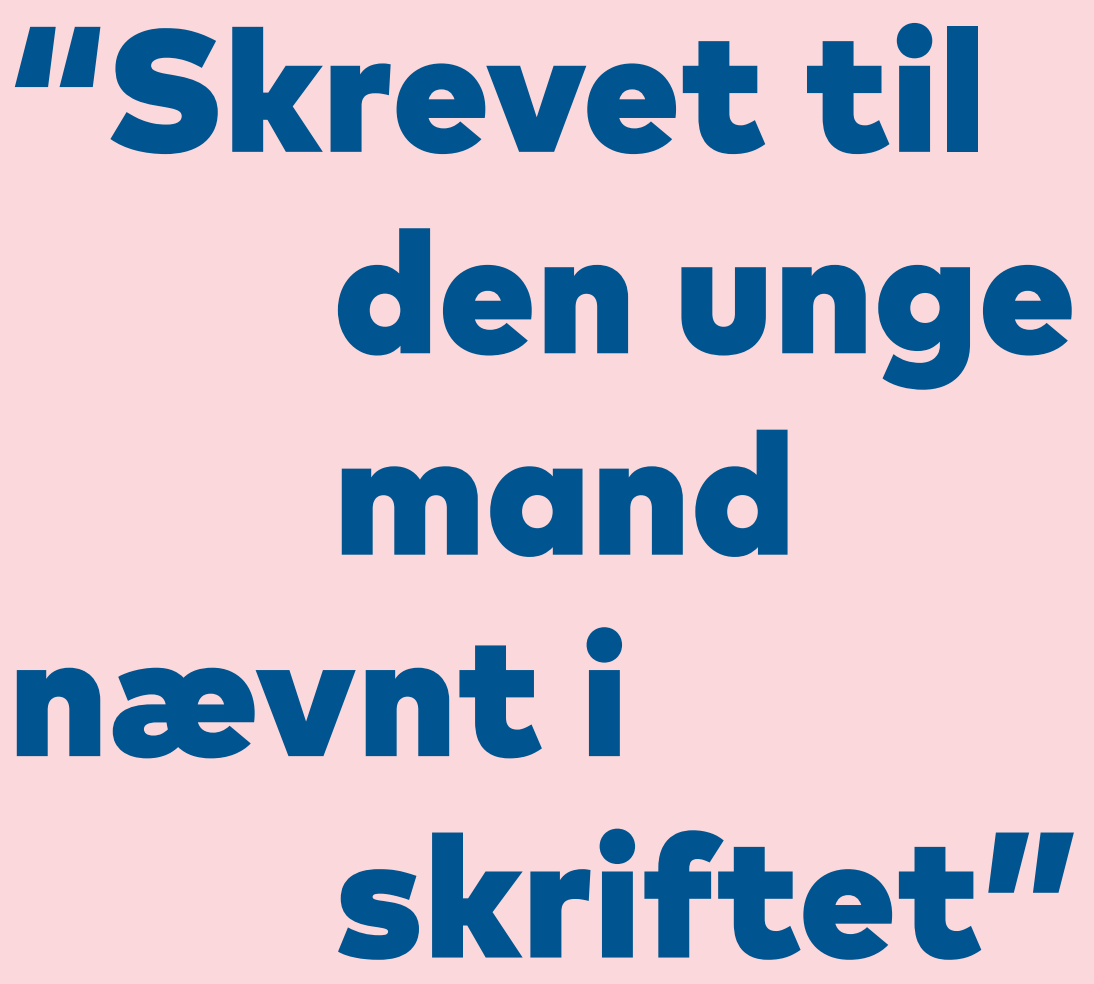

Tog en sten op i hånden, som jeg så ofte gør, elsker at slå smut. Men den her var ikke flad, men var bare en sten, som nu en sten kun kan være en sten. Jeg kylede den ud $i$ retning of ham.

Af Knud Steffen Nielsen (Danmark) 


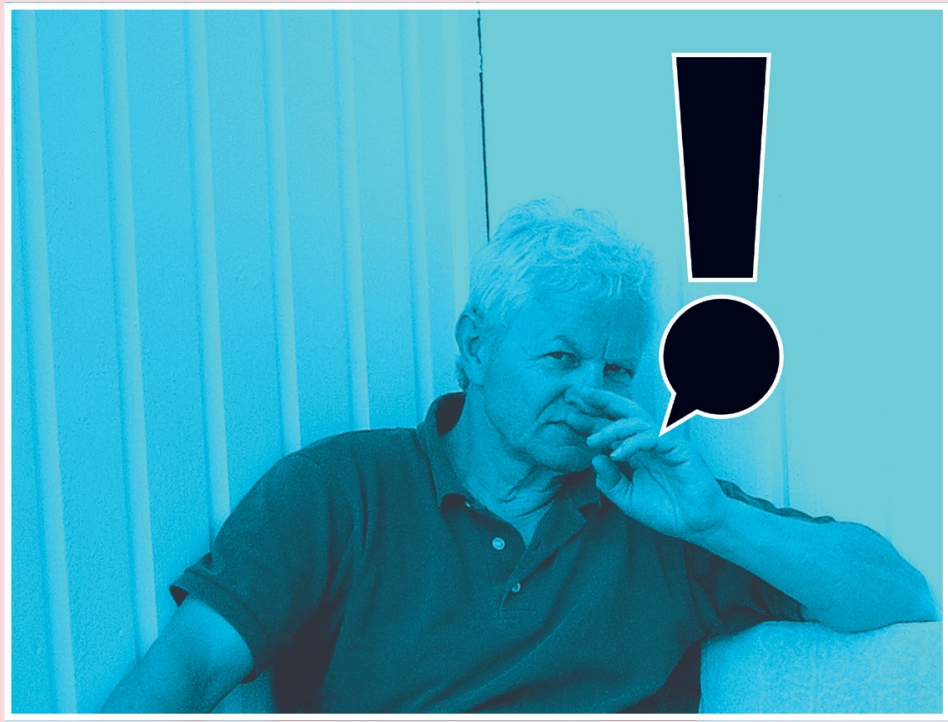

\section{Forfatteren Knud Steffen Nielsen sætter ytringsfrihed og had overfor hinanden - og os selv lige midt imellem.}

Som dreng tog jeg med mine forældre til stranden lige foran Kegnæs Fyr. Jeg må igen have været irriteret (eller værre ord, hvor den lille Ødipus indgår) på min far. Han var gået ud i vandet. Luften fuld af sommer og varme. Jeg var $i$ badekluns også. Det flimrede noget i mit hovedet. Tog en sten op $\mathrm{i}$ hånden, som jeg så ofte gør, elsker at slå smut. Men denher var ikke flad, men var bare en sten, som nu en sten kun kan være en sten. Jeg kylede den ud i retning af ham.
Ville/ville nok ikke ramme, men måske kun give ham en forskrækkelse ... men den kom uhyggelig tæt på ham.

Ville jeg fra et punkt nede i maven faktisk ramme ham?

Lagde vel i sidste øjeblik en lille deviation ind, sådan at jeg kun spillede scenen, mimede hvad det kunne være blevet i virkeligheden uden at ville virkeligheden. Og hvad var virkelighed af de to? Mere skete der ikke. Sådan åbenlyst.

Min barndoms urhistorie "Drabet på faderen" er også en påpegning af civilisationens skrøbelighed, den har så at sige også et freudsk over- og underjeg.

Ville drengen senere kunne smide en betonklods fra vejbroen i irritation? 
Eller kobles hans Overjeg sammen med Civilisationens kontrolinstans, dets Overjeg, fx besindigheden.

Dette vigtige forsinkelsesredskab i retshistorien, da blodhævn blev erstattet af et tredje, en slags instans udefra, og man pr. aftale (konvention så at sige) standsede op i at rive hoveder af hinanden i en lind strøm. Det var i hvert fald hensigten.

Men vi ved, at humanismens lak er tynd. Nedenunder ligger det freudske og bjæffer barbarisk.

Til drengen, der nu var 42 år, sagde nogle: "Nu efter 9.11. må der noget tortur til mod terroristerne".

Den skrøbelige udsathed vakler rundt mellem flg. friheder:

1. Ørnens frihed. Ørnens frihed er total og kan suspendere alle andre frihedsrettigheder. *

2. Spurvens frihed er at blive opædt.

3. Frihed som fra de gode, gamle dage: "Det var ikke mig, men hende, der begyndte."

4. Frihed i systemet: Hvorfor må jeg ikke køre gratis med sporvognen, den kører jo alligevel.

5. Friheden til at være slank: Fede mennesker bør tage sig sammen.

6. Patriarkalsk frihed. Faderen sagde: "Det er fordi far siger det." Drengen spurgte om den magnetiske Nordpol.
7. Min frihed: Jeg er modstander af andres postulater.

8. Frihed til at vise nåde: Mange vilde, oprindelige folk er flinke.

9. "Hvis du ikke slutter å blogge, skal jeg knuse trynet på foreldrene dine."

10. Kannibalens frihed. Man må godt være kannibal, hvis man kan argumentere for det.

11. Friheden for dig er til at blive som mig: Hvis bare dit legeme var identisk med mit, så ville det hele fungere bedre og mere dansk.

12. Frihed for hekse. Og hekse må vi definere bredt, da populationen er bred. Man skal bruge: Enten vandkuren, hvor du dør og derved frikendes. Eller vandkuren, hvor du kommer op til overfladen i live og derfor må dømmes til døden.

13. Friheden til at være opmærksom for at hjælpe samfundet: Jeg tror det skulende blik skyldes noget med pædofili.

14. Friheden ved at vide, hvor nogen bor: "Jeg ved, hvor du bor."

15. Og det skal du vide: jeg vil til enhver tid kæmpe for din ret til at mene det samme som mig.

\section{* Ornens frihed, 2.}

Racepleje a43. fragment herunder: "Et navn ud for hvert personblad, for hver patient./Ingen følelsesudtryk/ Forspildtheden er stadig blomsten der visnede, står der/. 
Scizofrenien er ikke en bæredygtig plante. / /Journal: ikke bæredygtig. / Johanne/ Sygdom nr. 14. ... uproduktiv, selvdestruktiv, kan kun finde ud af at trække øjenbrynshår ud og spise dem. /Et andet navn for forbandelse, den totale./ (I går fandt hun 7 firkløvere.// skal ikke noteres/)

Karakteristika for lægen, Hochschrab, ... overvejende nordisk, fast opret muskulatur kraftig brystkasse målbevidst fremadstræbende// fejlfri // uantastelig personlighed ægteskabsduelighed//12 $\mathrm{SIP}_{3} /$ VB9997756/ "arvesundhed". Ganske vist mangler undersøgelsesskema of hans konel/ Er forplantning i folkets interesse ønskeligt// forplantningsevne god// høj nytteværdi/ den mindre skæv- hed i ryggen er forbigående// prognose god//.

(Opgave, kun henvendt til skoleungdom, og især til dig, der tit må sidde og vente på de andre: Kan de anvendte generaliseringer på en måde siges at have strømafbrydelsens afcuttende karakter eller er det vrøvl? Hvad mener du?)

Knud Steffen Nielsen er lyriker, medlem af forskningsstyregruppen Center for ny Litteratur ved Syddansk Universitet og bestyrelsesnæstformand for Det Danske Forfatter- og Oversættercenter Hald Hovedgaard.

\section{"Written to the young man mentioned in the text"}

\section{8}

By Knud Steffen Nielsen (Denmark)

Knud Steffen Nielsen is a Danish poet.

I must again have been irritated (or a word which is worse where the little Oedipus pops up) with my father. He had gone into the sea. The air full of summer heat. I was wearing swimming togs too. My mind started to flicker. Picked up a stone, as I so often do; love skimming stones. But this one was not flat but just a stone, like a stone can only be a stone. I flung it in his direc- tion. Wished/Did not wish it to hit him but perhaps only give him a fright ... but it came unnervingly close to him.

Did I, from some gut feeling, in fact really want to hit him?

I wanted I suppose at the last moment a little deviation, in that I only imagined the scene, mimed what could have been reality without wanting reality. And of the two what was reality? Nothing more happened - at least not overtly. 
3. Freedom from the good old days.

My childhood's prehistoric history.

"Patricide" is also an indication of the

"It wasn't me who did it, it was she who started."

frailty of civilization; it has, so to speak, also a Freudian super ego and id.

Would the boy later be able to throw a concrete block from a bridge over a motorway in irritation?

Or has his super ego become coupled with the control mechanisms of civilization, its super ego e.g. moderations.

This important delay mechanism in legal history, when vendettas became replaced with a third, a type of external court and one by agreement (convention, so to speak), stopped tearing each other's heads off in a steady flow. That was at least the intention.

But we know that the varnish of humanism is thin. Underneath lies the Freudian and barks barbarically.

Some people said to the boy who was now 42 years old: "Now, after 9/11 you need some torture against the terrorists."

This frail exposure staggers between the following freedoms:

1. The freedom of the eagle. The freedom of the eagle is total and can suspend all other rights of freedom.*

2. The freedom of the sparrow is to be eaten.

4. Freedom in the system. "Why can't I travel free with the tram? It's running anyway."

5. The freedom to be slim. Fat people should pull themselves together.

6. Patriarchal freedom. The father said: "It is because father says so." The boy had asked about the magnetic North Pole.

7. My freedom. I am against the assertions of others.

8. Freedom to show mercy: Many wild, indigenous peoples are kind.

9. "If you don't stop your blogging I will smash your parent's faces."

10. The freedom of the cannibal. One can be a cannibal if one can argue convincingly for it.

11. Freedom for you is to be like me: If only your body was identical to mine everything would function so much better and more Danish.

12. Freedom for witches. And witches we must define broadly as the population is broad. One should use:

13. Either the water treatment where one dies and therefore is acquitted. Or the water treatment where one is pulled up to the surface alive and therefore must be given the death penalty.

14. Freedom to be observant to be able to help society: I think the scowling look has something to do with pedophilia. 
15. The freedom of knowing where somebody lives.

"I know where you live."
16. And this you must know: I would always, without exception, fight for your right to have the same opinion as me.
* The freedom of the Eagle, 2. Racial Care a43. Extract cited below: One name for each journal, for each patient./ No expressions of feelings/ The waste is still the flower that withered, as it is written/.

Schizophrenia is not a sustainable plant./ /Journal: not sustainable./ Johanne/ Disease number 14. ... Nonproductive, self-destructive, can only work out to pluck hair from her eyebrows and eat them. Another name for a curse, the total)./ (Yesterday she found 7 four-leaf clovers.// Not to be registered/)

Characteristic features for the doctor, Hochschrab, ... predominantly Nordic, firm erect musculature, strong chest determinedly ambitious// flawless // unchallengeable personality marriageability//12 $\mathrm{SIP}_{3} /$ VB9997756/ "original health". Although the medical examination form of his wife is missing //

Is reproduction in the interests of the people desirable// fertility good// high utility value/ the minor crookedness in the spine is temporaryll prognosis good//.

(Assignment, only for school children and students and especially for you who often has to sit and wait for the others: Can the above generalizations in a way be said to have the cutting character of a power cut, or is it nonsense? What do you think?) 
"Et mangfold og en allsidighet av så vel private medier som public service-medier er viktig, slik at så mange borgere som mulig kan delta direkte i den levende debatten som er så avgjørende for den demokratiske utviklingen av fellesskapet og samfunnet vårt."

Dagfinn Høybråten (Norge), generalsekretær i Nordisk ministerråd 


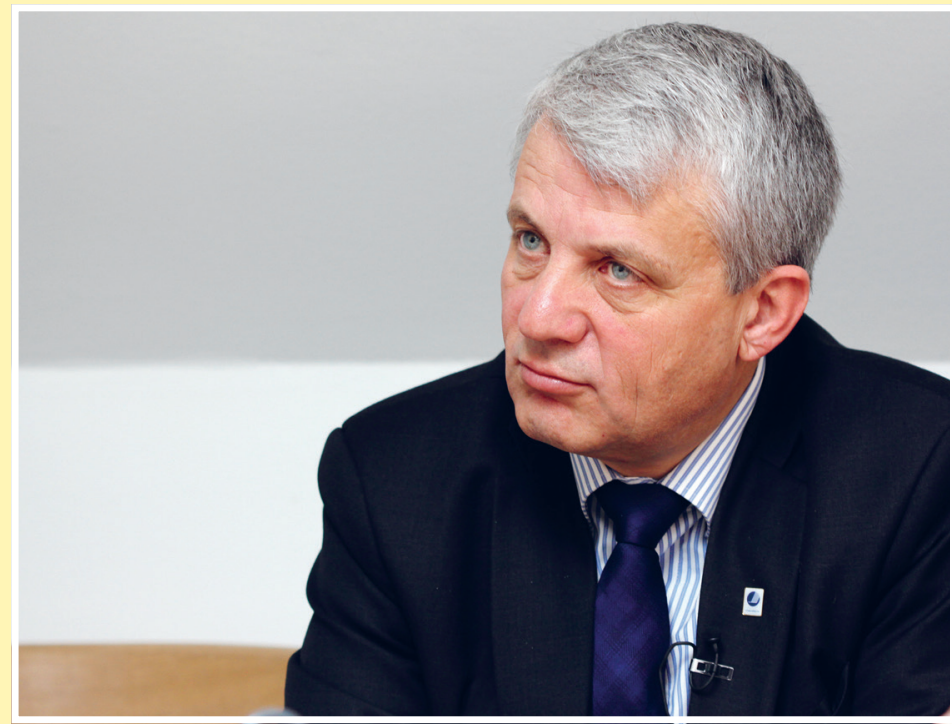

"Pluralism in private media as well as public service media makes it possible for citizens directly to take part in an open debate as a prerequisite for the development of our democracy."
Foto: Norden.org/

Thomas Glahn. 


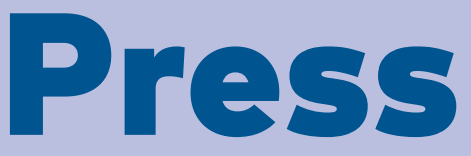

freedom in
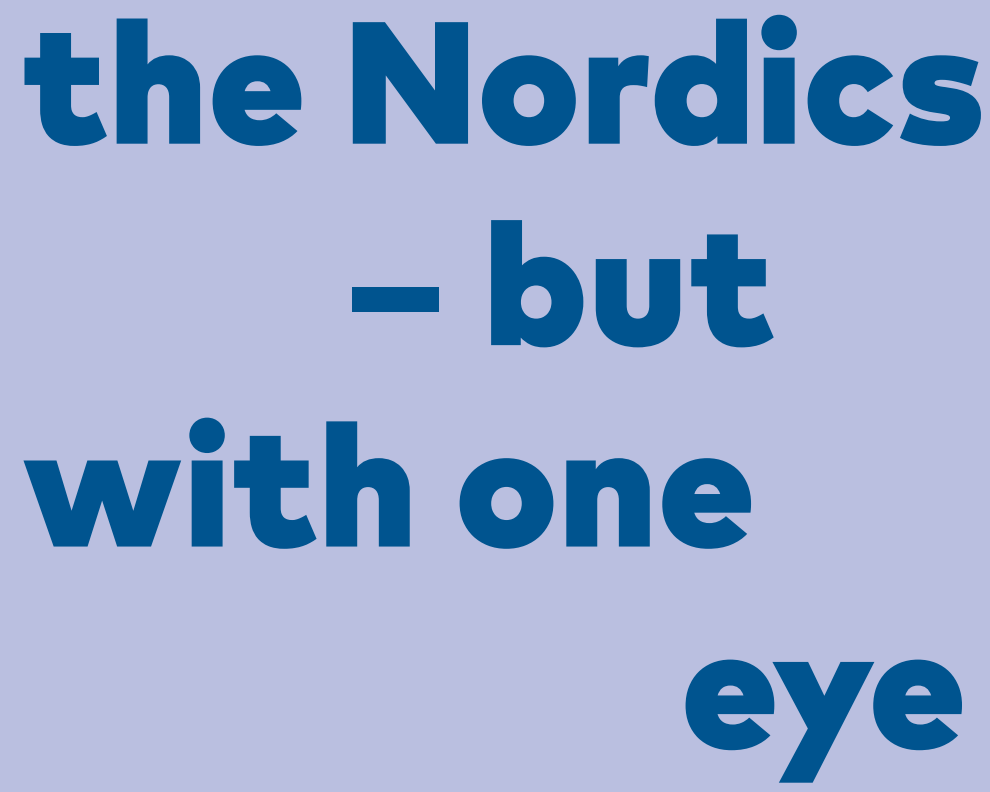

I left Damascus, the oldest capital in the world, and left the memories of my childhood and my career ...

By Ali Alabdallah (Sweden) 
Ali Alabdallah.

Photo: Hani Alkhateeb.

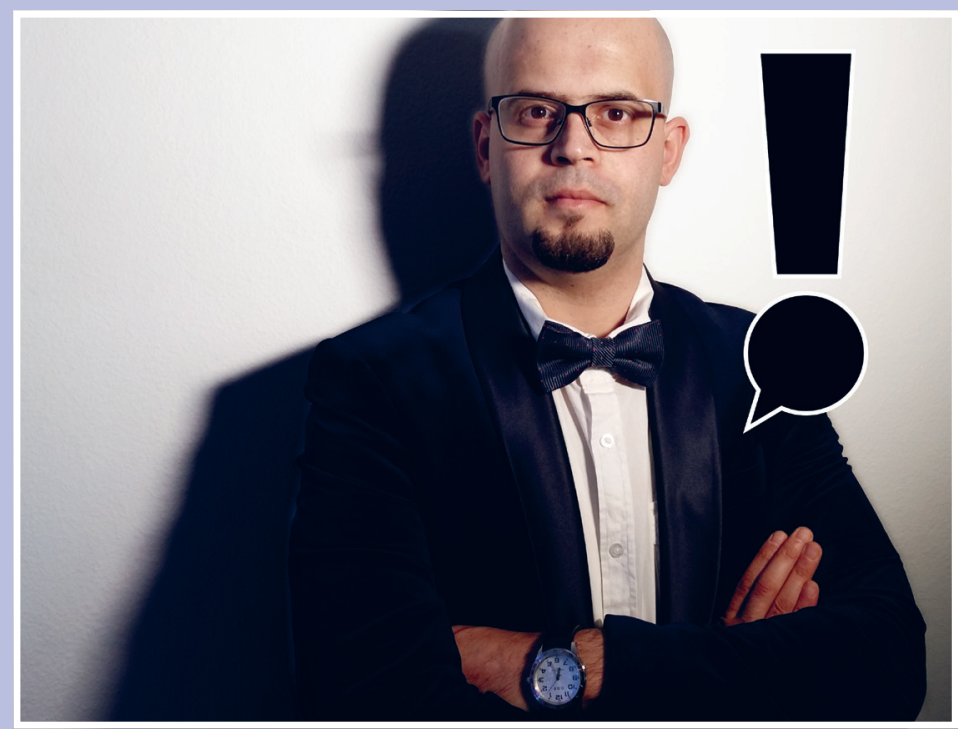

\section{Ali Alabdallah, Syrian} immigrant in the Nordics:

"I would advise every media outlet to be open-minded and include new voices of immigrant journalists. I believe that the media will gain when there is diversity in the press."

I left Damascus, the oldest capital in the world, and left the memories of my childhood and my career.

I reached Sweden, where as a journalist I found a country of a completely different view on free speech. It was a delight to meet the concept of press freedom in Nordic countries: I am able to express all my opinions freely!

Back in Syria, as a journalist at the largest Syrian newspaper Albaath, as a war correspondent for several Lebanese newspapers, and in the Syrian TV as well, I witnessed the presence of strict control on the media which leaves little room for press freedom. Governmental censorship on the media was not only annoying, but also worrying for journalists.

Despite the pleasure of learning and understanding freedom of the media in the Nordics, I found that something was wrong. 


\section{Despite the pleasure of learning and understanding freedom of the media in the Nordics, I found that something was wrong.}

\section{Why do media have more focus on the negative news of immigrants?}

How can press freedom be exercised through journalism without taking other opinions in consideration? In particular regarding the immigrants' opinions in all situations related to them as new citizens and regarding their home countries.

As a Syrian journalist entering Sweden in 2013, I asked all the media to be more careful in rhetoric. It is important to be precise like using Daash to describe the extremists Islamic groups instead of ISIS because ISIS is a bit of a misnomer and they are a terrorist group and not a state.

Furthermore, I have some observations regarding the media in Scandinavia. During the two years of my presence in this part of the world, I often notice looseness in journalism.

\section{Double standards}

First: I noticed a serious empathy gap in the Nordic media. In North Africa,
Middle East and South Asia, terrorist attacks are everyday life, and for us coming from that part of the world it seems, that media hardly notice this. In particular, it becomes obvious when two attacks take place at the same time. When terrorists in November 2015 made the appalling attack in Paris, while ISIS killed 43 civilians with a bomb in Beirut. Media in Western and Northern Europe focused on the Paris attack, though the same Daash was responsible for both attacks.

And we remember in the same time how Facebook was also accused of double standards when it gave the users of Facebook the option of putting a filter over their profile photos in the colors of French flag while failing to give their users the possibility of putting a filter over their profile photos in the colors of Lebanese flag. This was unfair for the Arab world.

\section{Imbalance in the news coverage}

Second: I find an imbalance in the news coverage regarding the news of immi- 
grants. The media focus on negative news of immigrants more than the positives news. We hear how difficult it is for refugees to learn Swedish or about the high level of unemployment among refugees.

For example, the Swedish radio had a project called \#100 voice, which includes 100 interviews with newcomers highlighting their difficulties to be a part of the labour market in Sweden and the difficulties of learning Swedish language. But why not questions about the successes of immigrants in Sweden and the other Nordic countries?

Why don't we learn more in the news about establishment of dozens of small companies, which at the same time is a way very quickly to learn the different Nordic languages? All these news are almost absent from the media, and it is not my impression, that other Nordic countries have more focus on this.
I have discussed these matters with many colleagues in the Swedish media and with many journalists that I met when I attended the UNESCO World Press Freedom Day 2016 in Helsinki, Finland. Among these journalists, they also agreed that the news about immigrants are mostly negative. One of the most frequent quotes during my conversation was:

"Unfortunately, the media focus on all the bad news, that attract people. Because it is generally believed, that the public cares more about negative news and events rather than the positive ones."

\section{My questions are:}

- Is it fair and balanced, if the media are inclined to prioritise negative news of immigrants, because of the relevance of the news is based upon the expectations from viewers, readers and listeners?

\section{I would advise every media outlet to be open-minded and include new voices of immigrant journalists. I believe that the media will gain when there is diversity in the press.}


- Does the media follow a more pragmatic way rather than sticking to independence and objectivity?

In my view, we should not forget that negative news about migrants focusing on their religion, in particular Islam, have caused an increase of racism and islamophobia. This trend is confirmed by the report published by the UN human rights committees.

\section{Media outlets should include new voices}

The absence of other voices and visions from the immigrants or the gap between Nordic journalists and immigrant journalists are some of the reasons, that the media in the Nordic countries create biased journalism about new citizens.

Therefore, I would advise every media outlet to be open-minded and include new voices of immigrant journalists. I believe that the media will gain when there is diversity in the press. Most importantly, it will surely have an impact on the integration and a better future, when the civic society receive the flow of news from a more balanced composition of those working in the media.

There are dozens of Syrian journalists migrated to Sweden, Denmark, Finland or other European countries, and the same situation is the case for a number of nationalities fleeing to the Northern part of Europe. It gives an opportunity to the media to include these journalists by making them their voices to be heard. That happened to me when I started writing dozens of articles for the Swedish newspapers.

We should encourage the media to highlight success stories of immigrants in the society. News stories can focus on, for example, how many of immigrants have learned the local language quickly. Another example is, that among other professions, well-educated people

\section{Why don't we learn more in}

the news about establishment of dozens of small companies, which at the same time is a way very quickly to learn the different Nordic languages? 
have arrived from the war zones, such as thousands of Syrian doctors with high-degree of skills.

Certainly, we have difficulties in finding a job. Because the Nordic media seems to have no trust in the skills and efficiency of immigrant journalists and thus hesitate to employ immigrants or to give them the opportunity of training. This is my situation.

When I came to Sweden, I asked the local newspaper in Arvika in Varmland, where I stayed after arriving, for the possibilities of training. They refused me because of financial reasons. They said: "We have no money for training." To me, it was really a strange answer. Because I was not asking for financial support for training but only a little bit of time.

\section{Possibilities and solutions}

As foreign journalists, we should have more possibilities to work or to have training provided by the Nordic media. In fact, many freelance journalists are more supportive for immigrant journalists than staff journalists working in both public service radio and TV and private media. Therefore, a little change of the approach could be very helpful regarding the possibilities of training and learning the basics of the Swedish press.

A few newspapers are interested in the views of foreign journalists, and they requested them to write articles. That's what I noticed personally when several newspapers asked me to write articles about the refugee crisis.

\section{When limiting press freedom reached the Swedish Foreign Minister}

We have press freedom in the Nordics countries and this is what gives us the opportunity to express our opinions freely across social media such as Facebook. Recently we noticed that there are limits to freedom of expression and this is what happened to the Swedish Foreign Minister, Margot Wallström. In January 2015, she exercised her right from an extremely important high position to tweet critical comments about Saudi Arabia's flogging of human rights activist and blogger Raif Badawi. She was criticized by the Swedish media as too vocal.

\section{We need a platform}

The advantage in an open society like Sweden is that it is easy to establish any media without any needs to get security approval like in Syria. Therefore, it was also easy for me to launch the first journalist initiative of dialogue in Landskrona, my new city.

I decided to call my media News Café. - Nyhetscafé in Swedish, and at the same time I launched a video channel on YouTube.

At News Café, I invited politicians and important community personalities 
and other persons to engage in an open dialogue about many relevant topics.

My participation in WPFD in Helsinki in Finland inspired me to improve my own business. Because I believe that Sweden and other Nordic countries need a platform for immigrant journalists. This is why recently I launched the immigrant journalists' association in Sweden (IJF) - Invandrare journalistförening i Sverige (ijf).

My goal is to promote the concept of diversity in the Swedish media by publishing articles, giving lectures, creating conferences and keeping contacts with the Swedish media. We should create friendships and improved relationships with the Nordic media. Another example is, that we initiated several media to have Arabic speaking outlets.

\section{Training is higly needed}

I believe that immigrant journalists needs more training in the field of media to increase their knowledge on democracy and media in Nordic countries in order to better understand the concept of freedom of information.
Mass media needs more courage to be inclusive in order to benefit from the experiences of immigrant journalists. In order to deliver ideas and creativities we in the immigrant journalists association include members across Sweden. We made a video about our association. In Sweden, I launched the first press initiative called News Café, a kind of citizen journalism.

Press freedom thrives in the Nordic countries, regardless of the difficulties described. I want to emphasize that the environment provides the possibilities for immigrant journalists to be creative and think freely without restrictions or censorship.

\section{Ali Alabdallah: Syrian journalist and} translator. Worked as a war correspondent in Syria. Lives in Sweden and works as a freelance journalist. Launched $\mathrm{Ny}$ hetscafé and the immigrant journalists' association in Sweden (IJF) - Invandrare journalistförening i Sverige (ijf) and received the cultural award in his city Landskrona (2015). 
IS IT FAIR AND BALANCED,

IF the media are inclined to

prioritise negative news

of immigrants, because of the

relevance of the news is based

upon the expectations from

viewers, readers and listeners?

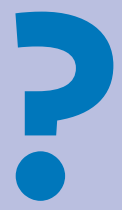

DOES THE MEDIA FOLLOW A more pragmatic way rather than sticking to independence and objectivity?

Ali Alabdallah (Sweden) 
Frie medier

er i alles

interesse

- også

magt-

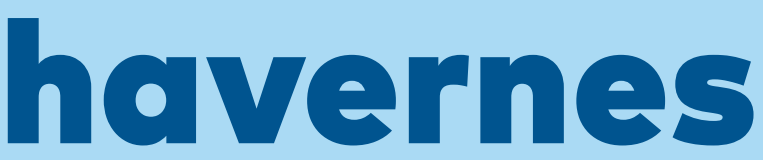

Ethvert demokrati er dybt afhængigt af den grundpille, som medierne skal være. Det er i alles interesse - i sidste ende også magthavernes.

Af Poul Krarup (Grønland) 
Poul Krarup.

Foto: Leiff Josefsen.

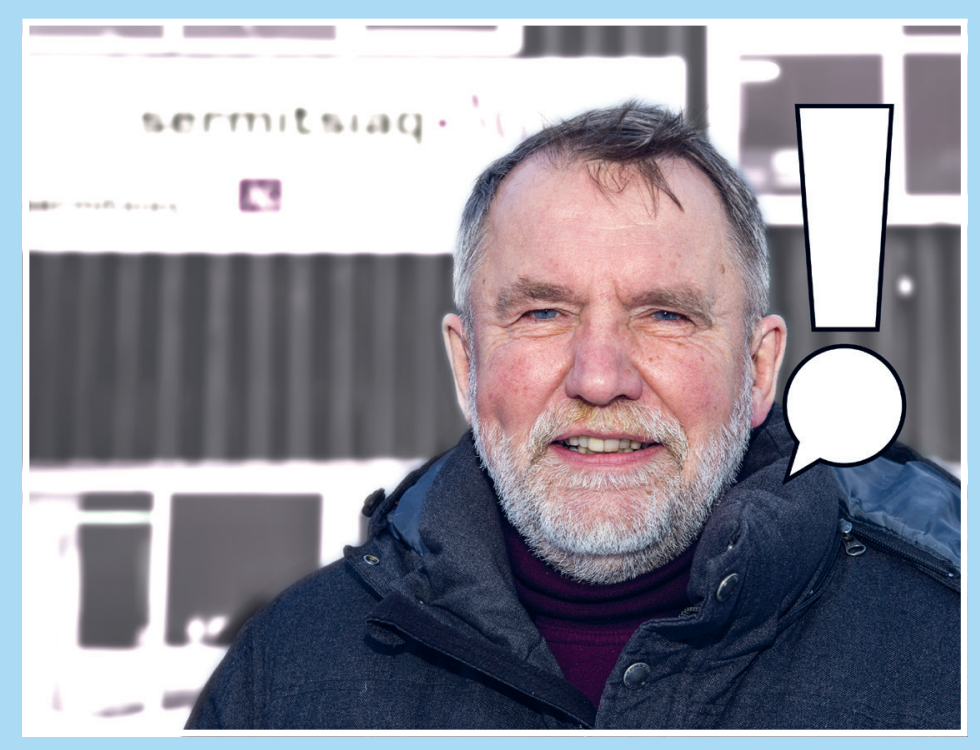

\section{På grund af det økonomiske} pres er der for få medarbejdere til at lave den nødvendige undersøgende journalistik, som er de uafhængige mediers eksistensberettigelse. Befolkningen får ikke den viden og indsigt, de har krav på.

Det grønlandske mediehus Sermitsiaq.AG mistede i 2014 sin mediestøtte på 2,5 millioner kroner fra selvstyret, selv om den var indarbejdet $\mathrm{i}$ årets finanslov. I slutningen af 2016 fik Sermitsiaq.AG så en del af mediestøtten igen med et beløb på 1,5 millioner kroner.
Mediepolitik, som er den rene zigzag kurs, kan blive en katastrofe for frie medier, fordi det vanskeliggør fornuftige, langsigtede forretningsmodeller.

Det gælder i store som små lande, og i Grønland bliver det svært at drive privat medievirksomhed, især for printaviser med tilhørende nyhedssider på nettet.

\section{Annoncer fjernes fra private medier}

En anden zig-zag kurs oplever vi mellem politikernes interesse for at optræde i medierne og annoncere i samme.

Når politikerne er på valg, er de meget optaget af at få deres synspunkter udbredt i aviserne. Så er det ikke 


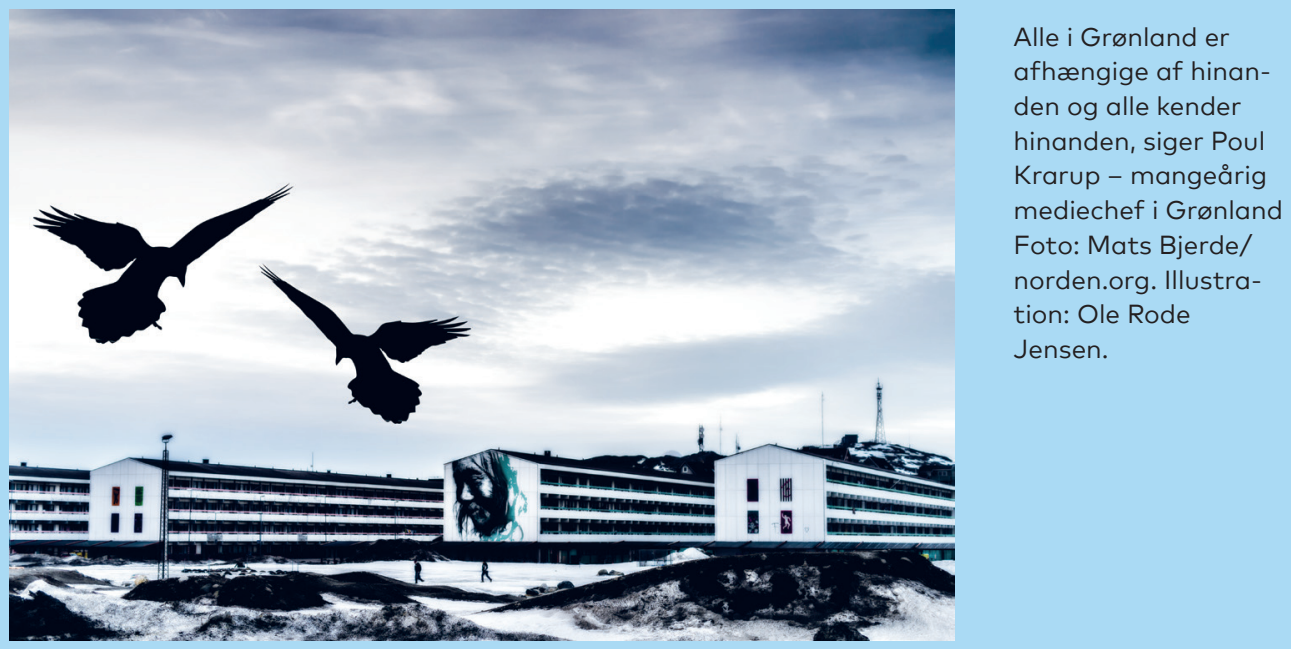

nok med diverse offentlige hjemmesider valgregler i avisannoncer - til skade for eller partiernes egne hjemmesider. Men private mediers økonomi. Vi ser samme når det offentlige skal annoncere informationer til befolkningen - såkaldte kundgørelser - så dropper de aviserne og bruger offentlige hjemmesider og pressemeddelelser.

For eksempel fjernede Inatsisartut (Grønlands parlament) i 2016 kommunernes pligt til at informere om valg og tendenser $\mathrm{i}$ andre lande.

Vores offentlige administrationer øger dermed blot de udfordringer, sociale medier tilføjer os, for det er her, mange annoncer rykker hen. Oven i alt dette kommer gratis online medier, som gør det vanskeligt at skaffe økonomi til at kunne betale journalisterne løn.

\section{En lang række online medier, der popper op uden kendskab til grundlæggende ideer om mediernes betydning, er ligeglade med presseetiske regler.}




\section{På grund af dårligere økonomi reduceres uafhængige mediehuse efterhånden til rene service- stationer, hvor de videreformidler andres oplysninger eller er rene mikrofonholdere for myndigheder, virksomheder og foreninger ...}

Samtidig fyldes offentlige kontorer og virksomheder med journalister og informationsmedarbejdere ligesom der oprettes masser af firmaer med journalistiske konsulenter, som nok skal hjælpe kunderne med at få de rigtige fortællinger ud.

\section{Ligeglade med etik}

Etikken har det også svært, for en lang række online medier, der popper op uden kendskab til grundlæggende ideer om mediernes betydning, er ligeglade med presseetiske regler. De kan godt finde på at offentliggøre navne på sigtede, anklagede eller anholdte, men ikke dømte, for at tiltrække læsere, eller de bringer billeder af trafikofre uden tanke for de hensyn, medierne skal vise og altid har vist.

\begin{abstract}
De sætter professionelle medier under pres og samtidig går det ud over troværdigheden, for hvad skal læserne, lytterne og seerne snart tro og mene?

I takt med udviklingen bliver de vafhængige mediehuse svagere og svagere og mere og mere afhængige af at skulle servicere kunder, som skal have bragt deres fortællinger, og som sådan godt kan bruge mediehusenes distributionskanaler.
\end{abstract}

\section{Undersøgende journalistik}

Den uafhængige, undersøgende journalistik betaler prisen. Eller rettere befolkningen, som ikke får den viden og indsigt, de har krav på.

De uafhængige mediehuses væsentligste styrke i dag er deres distributionssystem, deres læsertal og deres store netværk. 
Men på grund af dårligere økonomi reduceres uafhængige mediehuse efterhånden til rene service-stationer, hvor de videreformidler andres oplysninger eller er rene mikrofonholdere for myndigheder, virksomheder og foreninger med videre.

Netop fordi læserne har brug for disse informationer, er de vafhængige medier villige til at bringe dem for at sikre besøgstal og læsertal, men det bider sig selv i halen, for det giver ingen indtægter.

På grund af det økonomiske pres er der for få medarbejdere til at lave den nødvendige undersøgende journalistik, som er de uafhængige mediers eksistensberettigelse.

Samtidig stilles der større krav til journalisterne om at levere mere stof og gøre det hurtigere - og det hænger ikke sammen med at skulle bruge tid på research, og risikoen for fejl stiger.

\section{Løn afleses af klikhonorar}

På sigt vil vi kunne forudse, at mediehusene ikke har råd til at betale normal løn til journalister, der i stedet må tjene deres penge i forhold til, hvor mange læsere deres artikler har - hvor mange klik. Det betyder, at journalisten kun skal skrive det, som læseren selv mener at ville have, og ikke det, som fremstår på baggrund af et redaktionelt valg, og som journalisten vurderer er vigtig for læseren at vide.

For at kunne tjene penge skal journalisten levere noget unikt, altså ikke noget, som læseren kan få et andet sted gratis. Det betyder, at der skal arbejdes mere med artiklerne og være flere kilder på for netop at skabe der unikke, debatskabende indhold. Det stiller store krav til research og vinkling - netop det, som de privat mediehuse ikke har råd til.

Når de unikke artikler alligevel lykkes, bliver de kopieret af gratis medier, som bringer indholdet uden tanke på, at

\section{Netop i Grenland ser vi hele denne udvikling som en direkte trussel mod eksistensen of uafhængige medier og den undersegende journalistisk.}


det ophavsretligt tilhører andre journalister og medier. Læserne slipper i første omgang for at betale, for hvorfor købe en avis eller abonnere på net-indhold, hvis de alligevel finder det kvit og frit andre steder, og hvilket indhold kan man så stole på? Derfor er ophavsretten vigtig at holde fast $\mathrm{i}$, for den betyder noget på moralsk og økonomisk.

Netop i Grønland ser vi hele denne udvikling som en direkte trussel mod eksistensen af uafhængige medier og den undersøgende journalistisk.

\section{Forhindringerne}

Med kun 57.000 indbyggere i et kolossalt land er det svært at skabe indtægter. Distributionen er meget dyr, fordi offentlige myndigheder skal tjene på trafik- og transport- og kommunikationssystemerne i stedet for at yde tilskud, fordi de vil gøre det så billigt som muligt for befolkning og erhvervsliv samt medier.

Det lille indbyggertal betyder, at der er færre til at betale, skønt vi har læsertal, som forholdsmæssigt ligger højere end de store aviser i de befolkningsrige nordiske lande som Danmark, Norge, Sverige og Finland. Så er det heller ikke nok til at være interessante annoncesteder.

Den grønlandske økonomi er domineret af det offentlige. Der er forholdsvis få store virksomheder, som sidder på markedet, og de behøver ikke at annoncere, da de reelt ikke har nogen konkurrenter.

\section{Vigtig sprogpolitik}

Samtidig skal alle medier udgives på to sprog, og det skal respekteres, at grønlandsk er hovedsproget. På nyhedssiden Sermitsiaq.ag er de fleste brugere tosprogede, og de fleste bruger den dansk-sprogede side.

Men på Facebook foregår den meste debat og de fleste private informationer og meningstilkendegivelser på grønlandsk.

Her har mediehuset en klar udfordring og en vigtig opgave i at få tiltrukket den del af befolkningen, som kun taler grønlandsk og heriblandt unge mennesker, som kun kommunikerer på grønlandsk.

Interessant nok er der i Grønland netop opstået et rent dansk-sproget nyheds-site, Kamikposten.gl, hvis formål blandt andet er at give modspil til Sermitsiaq.ag. Siden er på det seneste begyndt at bringe få nyheder på grønlandsk.

Den ansvarshavende redaktør bor i Mexico, men hjemmesiden drives af et grønlandsk registreret selskab. Alligevel skriver man, at de presseetiske regler ikke gælder for Kamikposten.gl.

Skribenterne arbejder frivilligt, og man tillader anonyme skribenter. Det vil sige, der er tale om skruebrækkere i forhold til grønlandske journalister, som 
er medlem af en kreds under Dansk Journalistforbund.

Det er en interessant konkurrent for de eksisterende private medier i landet, som nu også er begyndt at operere på det i forvejen lille grønlandske annoncemarked. De kalder sig Grønlands største nyhedsmedie, hvilket de dog mangler at dokumentere, og som deres afstemninger absolut ikke tyder på.

\section{Svag debatkultur}

Alle i Grønland er afhængige af hinanden og alle kender hinanden.

Det lille samfund med kolossal offentlig dominans betyder, at der er en svag debatkultur. Ingen tør lægge sig ud med politikere eller embedsmænd, som sidder i bestemmende stillinger. De, der kender noget til en sag, deltager ikke i debatten med faktiske oplysninger. Det betyder, at en stor del af debatten kommer til at køre på forkerte forudsætninger.

Debattens grundlag er politikernes ønsker og håb samt løfter til befolkningen, og embedsmændene vover sjældent at gå ind og informere om realiteterne heri.

Virksomheder, som eventuelt skal realisere politikernes drømme, tør slet ikke udtale sig om realiteterne, for hvad mon der så sker med ordrerne?

Det skaber ofte et forkert beslutningsgrundlag, som i sidste ende rammer befolkningen.

De seneste katastrofer har været:
- Servicekontrakterne på trafikområdet, som ikke levede op til politikernes løfter og befolkningens/brugernes håb og ønsker.

- Uddelingen af fiskelicenser til makrel, som har betydet, at samfundet ikke har fået det ud af fiskeriet, som man havde forventet.

- Forsinkelser på råstofområdet, som har betydet, at samfundet har tabt mange millioner, og en hel region i Sydgrønland affolkes på grund af manglende mulighed for ny beskæftigelse, som politikerne har lovet i ti år.

- Boliger, som forfalder, og en folkeskole, som ikke kan leve op til aftagernes krav.

Eksemplerne er talrige og omvendt proportionale med stærke uafhængige, kritiske medier, der har tilstrækkelige resurser både i form af økonomi og journalister, som får den nødvendige opbakning til den vanskelige research $\mathrm{i}$ det lille samfund.

Ethvert demokrati er dybt afhængigt af den grundpille, som medierne skal være. Derfor skal fundamentet være i orden. Det er i alles interesse - i sidste ende også magthavernes.

Poul Krarup: Indtil marts 2017 direktør for mediehuset Sermitsiaq.AG. Ansvarshavene chefredaktør på avisen Sermitsiaq, hjemmesiden Sermitsiaq.ag og Nuuk Ugeavis samt The Arctic Journal. 


\section{Keeping the media strong serves the interests}

of voters and politicians alike

By Poul Krarup (Greenland) - Managing director of Greenland's largest privately owned media outlet 1990-2017. Editor-in-chief of Sermitsiaq, Nuuk Ugeavis newspapers, and The Arctic Journal.

In 2014, Greenland's government eliminated a national media subsidy that cost Sermitsiaq.AG, the country's largest media outlet, $\mathbf{2 . 5}$ million kroner. At the end of 2016, the subsidy was partially reinstated, and Sermitisaq.AG received $\mathbf{1 . 5}$ million kroner.

This sort of political flip-flopping makes it hard for media outlets to make long-term plans, which could prove disastrous for independent media in the long run.

This is true in big countries as well as small. But, in Greenland, it only adds to the hurdles faced by privately owned media outlets.

During election time, for example, candidates are eager to appear in the media. Once the election is over and it is time to pass on important informa- tion to the public, the official sites and press releases are enough all of a sudden. The media become unnecessary.

The media must also deal with the rise of social media and free publications, both of which undermine our business model, making it hard for us to keep our newsrooms staffed.

Getting a handle on these issues is vital, especially in a country like Greenland where a small population and an out-sized public sector makes people generally hesitant to speak out against the powerful.

The lack of proper information results in poor political decisions. In Greenland, the almost endless list of mistaken policies is inversely proportional to the decline of independent, critical media outlets.

The media makes up part of the foundation that helps keep democracies sturdy. Keeping the media strong, then, serves not just the national interest, but also serves politicians' interests. 
Sámi media

\section{adds value}
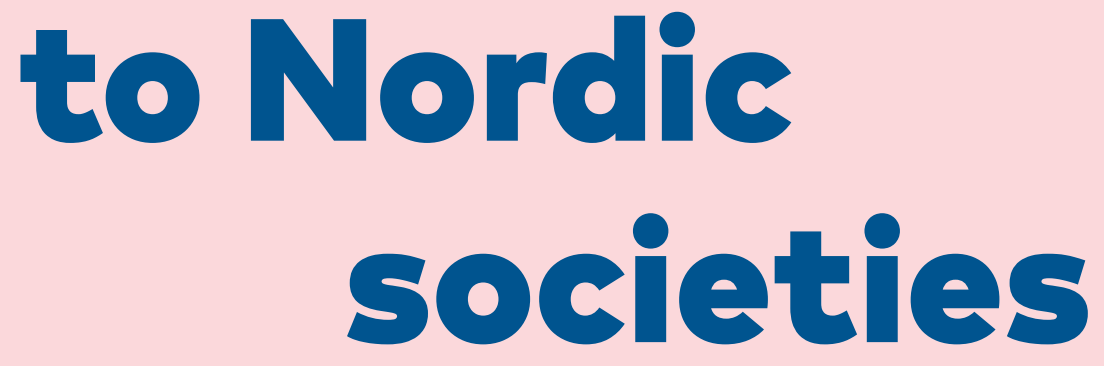

In 2017, Sámi people from Finland, Sweden, Norway and Russia celebrated the 10oth anniversary of the Sámi Nordic political cooperation. Sámi media emphasised the significance of working together as one people across the borders of the Nordic countries and Russia.

By Pirita Näkkäläjärvi (Sápmi, Finland) 
Pirita Näkkäläjärvi. Photo: Vesa Toppari/ Yle Bildtjänst.

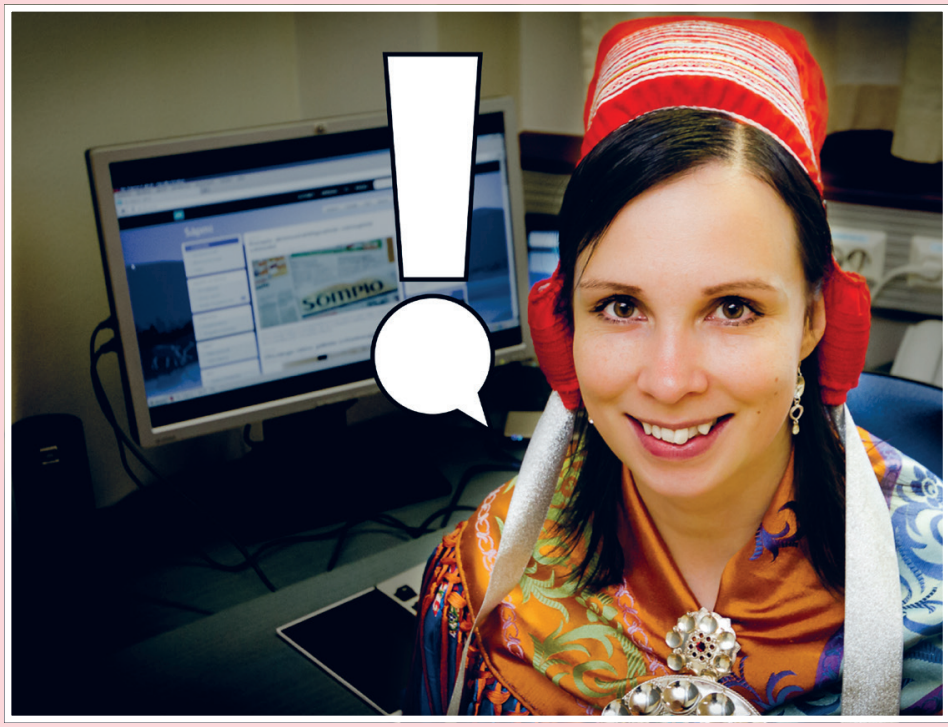

The world looks very different through Sámi eyes. The Sámi culture is distinct compared to the Nordic cultures

For a small indigenous people like the Sámi in Finland, totalling 10,000 people, their own media plays an important role.

Sámi media plays an important role in the Nordic democracy. Providing Sámi people with a trustworthy information good is an essential task in the Nordic democracy. Sámi media provides news from Sámi perspectives, gives a voice to a minority in the Nordic democracy, provides factual information and serves as a cultural institution.

The Sámi media adds value to the Nordic societies.

In Finland, there is only one daily Sámi-language media, Yle Sápmi. It is part of the Finnish Broadcasting Company, Yleisradio. Yle Sápmi provides content on radio, TV and internet in all three Sámi languages spoken in Finland.

On radio there are programmes for all ages. The internet and TV production focused on news. Part of the TV production is done in cooperation with the Sámi branches of Norway's NRK and Sweden's SVT. 


\section{News from Sámi perspectives}

First, Sámi media provides news from Sámi perspectives. The world looks very different through Sámi eyes. The Sámi culture is a distinct culture compared to the Nordic cultures. The Sámi worldview also differs from the dominant Nordic cultures.

What is news in the Sámi context differs from the Nordic context. Therefore it is important that media does not only reflect the Finnish, Swedish or Norwegian realities, structures and institutions.

It is essential that the media contains also Sámi stories that reflect the Sámi way of thinking. News from Sámi perspectives build understanding about the Sámi worldview. They also strengthen the identity of the Sámi people.

Accordingly, one of Yle Sápmi's strategic objectives is to add value to the Finnish society by bringing Sámi perspectives to public discussion. This way, Yle Sápmi is providing the public with Sámi information in order to serve the Nordic democracy.

\section{Voice of Sámi people}

Second, Sámi media is able to give the Sámi people a voice in the public discussion. One of the prerequisites is that Sámi media can exercise its freedom. This means for example getting to decide their own agenda freely.

One of the challenges for the Sámi people in Nordic countries is that the Sámi voice is not properly heard in decision-making processes, although it is required by law to negotiate with the Sámi people in matters affecting them.

The Sámi Parliaments are the official representatives of the Sámi people in Finland, Sweden and Norway. They are heard but seldom consulted properly in matters affecting the Sámi people.

Only hearing the Sámi Parliaments does not fulfil the requirements of the Free, Prior and Informed Consent, FPIC, as set out in the United Nations Declaration on the Rights of Indigenous Peoples (UNDRIP).

Moreover, recently there have even been cases, in which the Sámi Parlia-

\section{It is essential that the media contains also Sámi stories that reflect the Sámi way of thinking.}




\section{Hear Sámi stories. Listen to Sámi music. Get information about the Sámi culture ... Hear archive interviews of your Sámi ancestors.}

ment in Finland has not been heard, let alone consulted in matters affecting the Sámi people.

This is where the Sámi media comes in.

Sámi journalists are able to raise to the public discussion issues that are significant to the indigenous Sámi people. In this way, Sámi media is able to provide a channel for the Sámi voice to be heard, even if the voice gets neglected in the official decision-making processes.

\section{Factual informa-}

\section{tion about the Sámi}

Third, Sámi media can also function as provider of correct, factual information. This factual information is important to both Sámi and the majority populations in Finland, Sweden and Norway.

The significance of the information about the Sámi is that dialogue about Sámi issues should be based on facts, not on fake news or alternative facts. Factual information about the Sámi people is an essential ingredient in a constructive dialogue and a functioning Nordic democracy.

Sámi media can also expose structural issues in the discussion on Sámi issues. Journalists belonging to the majority population often choose a different framing compared to their indigenous colleagues.

Comparing the coverage of Sámi issues by both the mainstream media and the Sámi media can reveal major differences in perspective, framing and even epistemology of news.

\section{Cultural institution}

Finally, in addition to playing an important role in the Nordic democracy, Sámi media is also a significant cultural institution.

Sámi media is one of the only places where you can hear and read Sámi languages every day. Hear Sámi stories. Listen to Sámi music. Get information about the Sámi culture. Hear new Sámi-language words developed for 


\section{The Sámi languages contain Sámi worldview, philosophy and structures of thinking.}

modern phenomena. Hear archive interviews of your Sámi ancestors.

This is why Sámi media is more than just media for the Sámi people.

The significance of producing and working in Sámi languages is that in doing so, all thinking starts from Sámi perspectives.

In Finland there are three Sámi languages: Northern Sámi, Inari Sámi and Skolt Sámi. Yle Sápmi provides TV, radio and internet content in all these languages.

The proportion of the minority Sámi languages, Inari Sámi and Skolt Sámi, has consciously been increased over the course of the years in order to support the efforts to revitalise these languages.

Yle Sápmi is also one of the only workplaces in Finland, where Sámi languages are the daily working languages.

Sámi languages carry the Sámi history, customs and worldview. By originating news in Sámi languages, the starting point is Sámi perspectives - as opposed to translating into the Sámi-languages news, that were originated in the Finnish language and from the Finnish point of view.
Content originated in the Sámi languages (and only later translated into Finnish and English) strengthens the Sámi culture. The Sámi languages contain Sámi worldview, philosophy and structures of thinking. A conscious choice to have a production strategy of 'Sámi languages first' strengthens the Sámi society and the Sámi culture.

\section{Sámi National Day 2017 in media}

To conclude, I will give an example about the differences between the mainstream media and the Sámi media.

The Sámi National Day is celebrated on the 6th of February every year. 2017 was a special year, as it marked the 10oth jubilee of the Sámi Nordic political cooperation. The common Sámi jubilee celebrations were held in Trondheim, Norway.

On the Sámi National Day 2017, hundreds of Sámi people from Finland, Sweden, Norway and Russia were gathered in Trondheim. The historical day was marked around the city of Trondheim. The opening ceremonies were on the city centre. 
The three presidents of the Sámi Parliaments in Finland, Norway and Sweden stood side by side and delivered their remarks. The story of Mrs. Elsa Laula Renberg, the Sámi politician who originally gathered Sámi people in Trondheim a hundred years ago, was reminisced, highlighted and celebrated.

On the Sámi National Day 2017, all eyes of the Sámi media were on the Sámi 100 year jubilee celebration in Trondheim, Norway.

The three Sámi radios worked as one team and sent common daily broadcasts on the radio and online from the centre of Trondheim. The Sámi print media on the Norwegian and Swedish side of the Sámiland was filled with news and pictures from the week-long celebrations around the city of Trondheim.

One of the main Sámi news narratives arising from the Sámi jubilee week was the idea of a united Sámiland. The Sámi news coverage concentrated especially on the debate about creating a common Sámi Parliament instead of three separate Sámi Parliaments in Finland, Norway and Sweden. Combining the three Sámi broadcasters together as one Sámi media was also discussed.

Looking at the Finnish mainstream media coverage on the Sámi National Day 2017 reveals a very different picture.

As the Sámi media was busy covering the common Sámi jubilee celebrations in Trondheim, the Finnish mainstream media hardly mentioned the Trondheim festivities. No Finnish journalists were sent to Trondheim to cover the event.

Instead, Finnish journalists were gathered in Inari on the Sámi National Day 2017. The village of Inari is the centre of the Sámi home region in Finland. The eyes of the Finnish media were on the president of Finland Sauli Niinistö. The reason was that president Niinistö started his tour marking Finland's 100 year jubilee in Inari. Finland will

\section{Sámi media focused on the the significance of working together as one people across the borders of the Nordic nation states and Russia.}


celebrate her 10oth independence day in December 2017.

So instead of Trondheim, where the Sámi from four countries were gathered, the Finnish-language news stories of the Finnish Broadcasting Company, Yleisradio, as well as of Lapland's only provincial newspaper Lapin Kansa, were centred around president Niinistö's visit in Inari.

This example reveals a major difference in perspectives.

The Sámi media prioritised the common Sámi jubilee celebrations in Trondheim.

The Sámi perspective could be seen in the way that the Sámi media emphasised the cross-border nature of the 100 year Sámi jubilee. The news narratives focused on the the significance of working together as one people across the borders of the Nordic nation states and Russia.

People following the Sámi media coverage on the Sámi National Day
2017 also learned a lot. There was information about the Sámi history across the borders as well as the contemporary Sámi society.

The Sámi National Day example illustrates the importance of the Sámi media. They were providers of a public Sámi information good, which is an essential ingredient in the Nordic democracies.

Pirita Näkkäläjärvi is the Head of Yle Sápmi in Inari. She is however currently on study leave at London School of Economics, UK. She is taking an MSc Media and Communications at LSE. Miss Näkkäläjärvi also holds an MSc in Economics from Helsinki School of Economics, Finland. Before Yleisradio she made a business career at Metso, Booz \& Company, Nokia and Merrill Lynch. 
II The Sámi perspective could be seen in the way that the Sámi media emphasised the cross-border nature of the 100 year Sámi jubilee. The news narratives focused on the the significance of working together as one people across the borders of the Nordic nation states and Russia.

Pirita Näkkäläjärvi (Sápmi, Finland) 


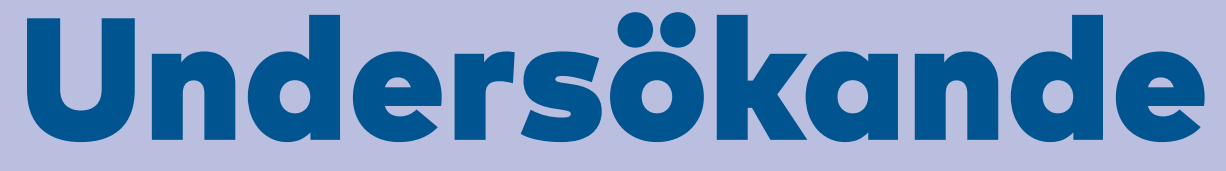

journalistik
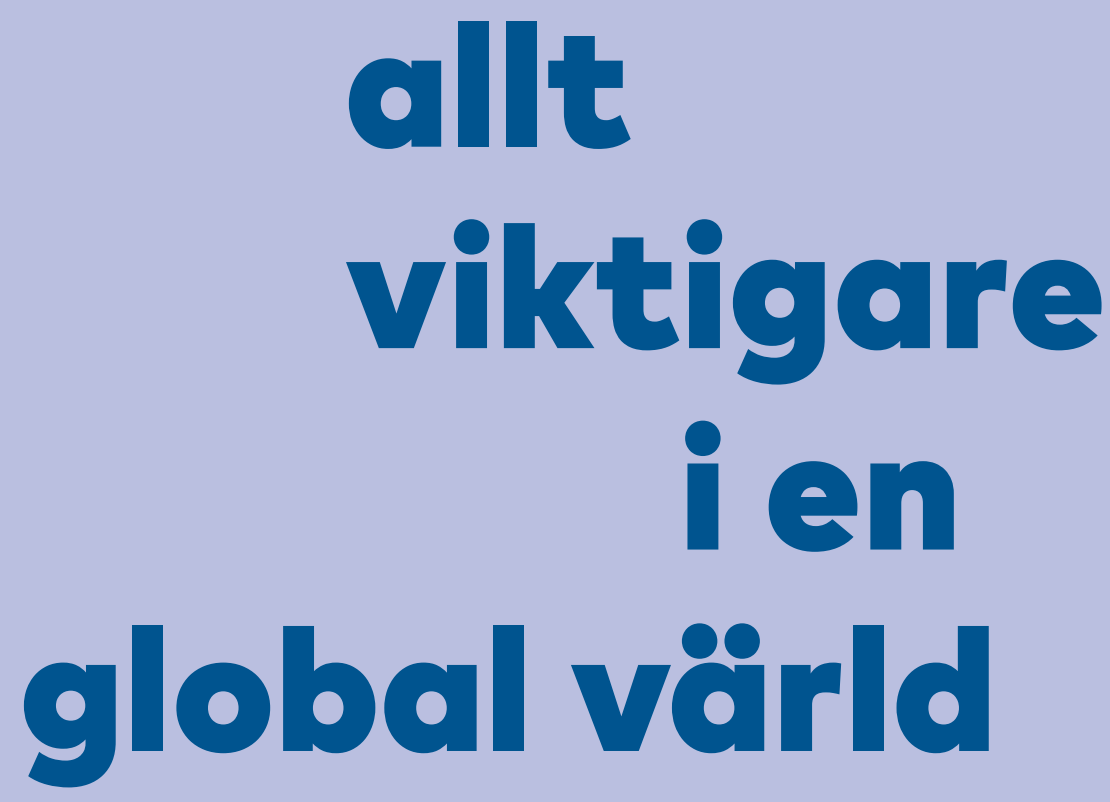

Populismen ger enkla svar på svåra frågor. Den undersökande journalistikens trovärdighet ligger i att alltid få fram och presentera korrekt fakta.

\section{Av Axel Rappe (Finland)}


Axel Rappe.

Foto: Pauli Boström/

Yle Bildtjänst.

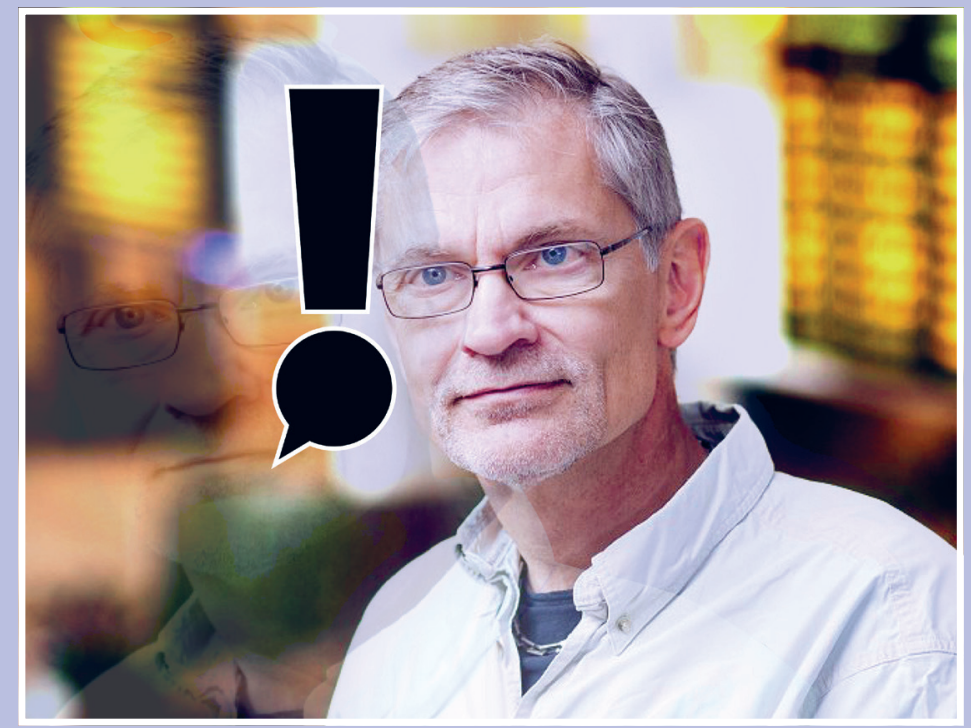

Undersökande journalistik blir allt viktigare. Därför är samarbete mellan grävande journalister avgörande: det ger större resurser för research och internationella nätverk ger en större genomslagskraft. Politiker och myndigheter tar nyheten mera på allvar om det finns en stor spridning och en täckning redan på en nordisk nivå.
Grävande journalister är ofta öppna för ett samarbete. Det kan vara att knyta kontakter och hitta gemensamma projekt på grävseminarier. Grävseminarier kan jämföras med väckelsemöten där frälsningen är att få höra om andras projekt och deras metoder.

De bästa resultaten uppnås om alla i ett grävprojekt är med från början. Det är svårare att komma in i materialet och hitta en ingång om det redan finns ett färdigt framresearchat material.

- Det är som att hoppa på ett tåg i farten, konstaterar Minna Knus-Galán från Yle:s grävande program MOT. Hon gjorde en finländsk vinkling på SVT:s Uppdrag Gransknings research om 


\section{ID Journalister jobbar dock mycket på en nationell nivå. Det kan också käinnas besvärligt att kontakta en kollega i ett annat land.}

oavlönade och kontraktslösa arbetare som byggde upp OS byn i ryska Sotschi.

\section{Lo̊g tröskel men mycket finns att göra}

Tröskeln för nordiska grävsamarbeten är låg. Offentlighetslagstiftningen och kulturen i de nordiska länderna liknar varandra. Det finns också flera nordiska kopplingar inom näringslivet och organisationer.

De nordiska public service bolagen har ett organiserat samarbetsforum. Däremot är samarbetet mellan kommersiella medieföretag mera sporadiskt, detta trots att vi har medieföretag med verksamhet i flera nordiska länder.

Journalister jobbar dock mycket på en nationell nivå. Närsamhället, det lokala anses vara det som gäller för att fånga publiken. Men i en allt mer global värld så är närsamhället en liten kugge i ett större spel. Det kan också kännas besvärligt att kontakta en kollega i ett annat land.

\section{Vikten av gräv ökar}

Betydelsen och vikten av undersökande journalistik ökar. Jag ska här nämna några saker:

Vi har för det första den globala marknaden. Här verkar allt fler företag. Det kan vara allt från företag som flyttar produktionen utomlands till mångnationella företag. En del företag vill med alla medel uppnå vinst och det kan betyda olagligt eller omoraliskt beteende.

Sedan har vi en allt mer organiserad global brottslighet. Det är allt från organiserade motorcykelgäng som handlar med vapen och droger till odemokratiska organisationer som Nordiska motståndsrörelsen.

Det är också fråga om ett lands försök att påverka opinionen i ett annat land eller direkta cyberattacker. Ett annat globalt fenomen är värvningen av terrorister.

För det andra ökar behovet av undersökande journalistik när den ekonomiska politiken i flera länder styrs av nedskärningar. Det är en politik som 
drabbar olika grupper i samhället och då behövs konsekvensanalyser och klargörande om politikens syfte och motiveringar. Här är det också fråga om internationella institutioners verksamhet, t.ex. EU.

En annan tendens är att statliga och kommunala verksamheter, som till exempel trafikverk och elverk, bolagiseras. Det får negativa konsekvenser för insynen. Ett exempel: I Finland finns de flera kommunalt ägda elverksaktiebolag som gått med i kärnkraftsbolaget Fennovoima. Hur deras avtal ser ut och vilka ekonomiska skyldigheter de har när kärnkraftverket i Pyhäjoki ska börja byggas är en aktiebolagshemlighet.

Jag ska ge några exempel på gränsöverskridande grävande journalistisk, där tyngdpunkten ligger på vilka erfarenheter journalister har av att gräva tillsammans.

\section{Erfarenheter av gränsöverskridande gräv}

Under året 2016 kom historiens hittills största läcka med ca 11,5 miljoner dokument om hur företag och personer över hela världen har använt en advokatbyrå i Panama för att dölja sina tillgångar med så kallade brevlådeföretag.

Hundratals journalister över hela världen gick under ett drygt år igenom Panamadokumenten. Det hela organiserades av den internationella journalistorganisationen ICIJ.
Granskningen av dokumenten gjordes i största hemlighet. En nordisk grupp bildades med grävande journalister från Sveriges SVT, Finlands YLE, Norges Aftenposten, Danmarks DR och en frilansjournalist från Island.

För Nordens del kunde Panamadokumenten avslöja bland annat att Islands dåvarande statsminister hade gömt pengar i ett offshore bolag. Den nordiska banken Nordea hade hjälpt kunder att bilda offshore bolag i skatteparadiset Panama för att undvika skatt.

\section{Att kunna lita på varandra}

Erfarenheterna från samarbetet med Panamadokumenten var att alla i gruppen måste ha förtroende för varandra. Alla måste kunna dela all information med varandra och vara överens om tillvägagångssättet.

Flera grävande journalister säger att det är viktigt att ha förtroende för varandra. Att ingen lurpassar på den andra eller bränner av något innan man är i mål. Med ett större team kan man få fler idéer samtidigt som det finns ett bollplank.

Trots att vikten av grävande journalistik ökar, eller kanske just därför, så finns det oroväckande tendenser som hotar den undersökande journalistiken. 


\section{Hot mot den undersökande journalistiken}

Med allt fler visselblåsare (whistleblowers) som läcker information med delikat innehåll, så får allt fler företagsledare och politiker kalla fötter. Det har vi sett i USA efter Wikileaks och Snowdens avslöjanden. Både Wikileaks grundare Assange och Snowden lever i exil för att undgå straff i USA.

I Finland begärde skattemyndigheterna att få ut Panamadokumenten. De grävande journalisterna Minna Knus-Galán och Kjell Lindroos hotades med husrannsakan och deras bolag YLE utsattes för politiskt påtryckning av dåvarande statsministern Alexander Stubb.

Public service bolaget YLE har överklagat till Helsingfors förvaltningsdomstol med hänvisning till källskyddet. Ärendet har ännu inte avgjorts i rätten.

Men som Süddeutche Zeitung (som fick alla Panamadokumenten) har konstaterat: Ger vi ut Panamadokumenten så är det sista gången vi ger ut några hemliga dokument överhuvudtaget. Om en visselblåsare inte får skydd finns det inget förtroende längre för media, och avslöjandena torkar in.

\section{Tidsbrist och minskade resurser}

Ett annat problem inom dagens journalistik är okunskapen. Tidsbrist och dålig bakgrundsinformation gör att många påståenden och åsikter får passera oemotsagda. Medier gillar också åsikter framom sakkunskap.

När desinformation sprids via etablerade kanaler som t.ex. MV-lehti i Finland, blir det allt viktigare att stå emot och avslöja lösa påståenden. Det visar inte minst Brexit och Donald Trumps presidentvalskampanj. Med andra ord populism ger enkla svar på svåra frågor där det skulle finnas så mycket mer att gräva i.

Ett annat stort hot är när etablerade mediehus av ekonomiska skäl skär ned på den grävande journalistiken. Detta gäller till exempel MTV i Finland. Den grävande journalistiken anses för dyr då det kan ta lång tid att få fram avslöjanden.

Visst har egna nyheterna blivit något av ett varumärke för etablerade mediehus. Korta gräv och enkla faktabaskörningar kan ge en hel del egna nyheter. Men de stora avslöjandena, kartläggningarna och berättelserna om vart samhället är på väg uteblir lätt om

\section{Ett annat problem inom dagens journalistik ör okunskapen.}


det inte ges tid för att gräva. Om inte de kommersiella medierna kan göra det så är detta en uppgift för public service.

För om journalistiken har rollen av en vakthund, det vill säga att kontrollera maktutövningen och dess konsekvenser har den undersökande journalistiken också rollen av en blodhund och en grythund. Det vill säga att spåra och gräva fram olägenheter och missförhållanden. Det kan också vara konsekvensbedömningar eller analyser med ett helikopterperspektiv där beslut, beteende med mera, sätts i ett större sammanhang för att se vart samhället är på väg.

\section{Hur sprida god journalistik?}

Det är lätt att slå fast att grävande journalistik ska intressera en bred allmänhet. Det är dock betydligt svårare att genomföra det i praktiken. Precis som med all seriös journalistik idag är frågan hur ska nyheter och bra berättelser nå en bred publik?

Nyheter i sig är inte längre något eftertraktansvärt på en infomartionsmarknad där allt flödar fritt och där publiken är allt mer fragmenterad. Mycket långt följer individen den egna bubblans värld.

En bra story, en bra berättelse kommer alltid att stå sig och ett bra gräv kommer alltid att väcka till insikt. Men i dagens flöde blir det allt viktigare att få ut nyheter och berättelser där publiken finns. I annat fall försvinner gräven lätt.
Den undersökande journalistikens trovärdighet ligger i att alltid få fram och presentera korrekt fakta. Arbetsverktygen för att nå dit har utvecklats. Det kan vara att få hjälp av publiken eller de som är direkt berörda av problemet man undersöker, det vill säga crowdsourcing. Med datajournalistikens hjälp kan databaser utnyttjas på nya sätt genom att ställa nya frågor om informationen eller så kan två eller flera databasers innehåll föras samman för att få fram nya samband.

\section{Engagera och ge något unikt}

Det gäller att fila på formen och se till att storyn delas på sociala medier. Det kan vara att engagera publiken och få med den i grävprocessen eller att få dem med i finansieringen av gräv. Det blir allt vanligare med fristående grävgrupper och grävsaiter som till exempel Long Play i Finland.

Det kan också vara att öppna upp grävprocesser och berätta hur man går till väga. Eller ta emot tips från allmänheten, vilket är ett led i tanken om att journalistiken ska ge det folket vill ha.

Men grävande journalistik ska inte bara ge det vad man tror att publiken vill ha. Konsumtionsjournalistik är bra men grävande journalistik är större än så.

I dagens värld där populismen florerar, där osanningar får sväva fritt, är det mycket viktigt att ta fram sådant som publiken inte visste att de skulle 
behöva veta. Analys, vägledning och upplysning om vad olika saker betyder och har för konsekvenser är viktiga gräv. Gräv om rörelser i samhället och om politiska bevekelsegrunder avslöjar samhällsutvecklingen och ger redskap för publiken att kunna förstå hur landet ligger till.
Axel Rappe: Jag är reporter vid Svenska Yle (Finland) och jobbar med det grävande teveprogrammet Spotlight på Yle Fem och för webben svenska.yle.fi. Jag har jobbat som nyhetsjournalist och de senaste tio åren som undersökande journalist: allt från researcher till t.f. producent. Jag är allätare men följer främst med energifrågor och säkerhetspolitik.

\section{Globalisation demands investigative journalism}

4 近

By Axel Rappe (Finland)

Axel Rappe is a reporter and investigative journalist with Yle /Finnish television.

Today we see threats to the investigative journalism. Authorities want to suppress whistleblowers (such as in the USA) and force journalists to release their sources (in Finland).

Many media companies dismantle the investigative journalism while trying to seek unique story to be one of a winning concepts to achieve the public.
At a time when disinformation, populism and threats are prevailing, it is vital to have investigative journalism.

International cooperation among investigative journalists helps obtain more resources for research and increases the impact of their works. Politicians and authorities cannot easily avoid scrutiny if they are exposed at international level.

Investigative journalism has to inform, expose and analyse what is going on in the society. That is to tell the public truth, that they don't know that they need to know. 
II I Finland begärde skattemyndigheterna att få ut Panamadokumenten. De grävande journalisterna hotades med husrannsakan och deras bolag YLE utsattes för politiskt påtryckning av dåvarande statsministern. Axel Rappe (Finland) 


\section{Folk må}

oppiate

ot journalistikk

gjor

en forskjell

Å redde journalistikken krever at folk har tilstrekkelige åpenbare grunner til å stole på det som står der.

Av Kjersti Løken Stavrum (Norge) 


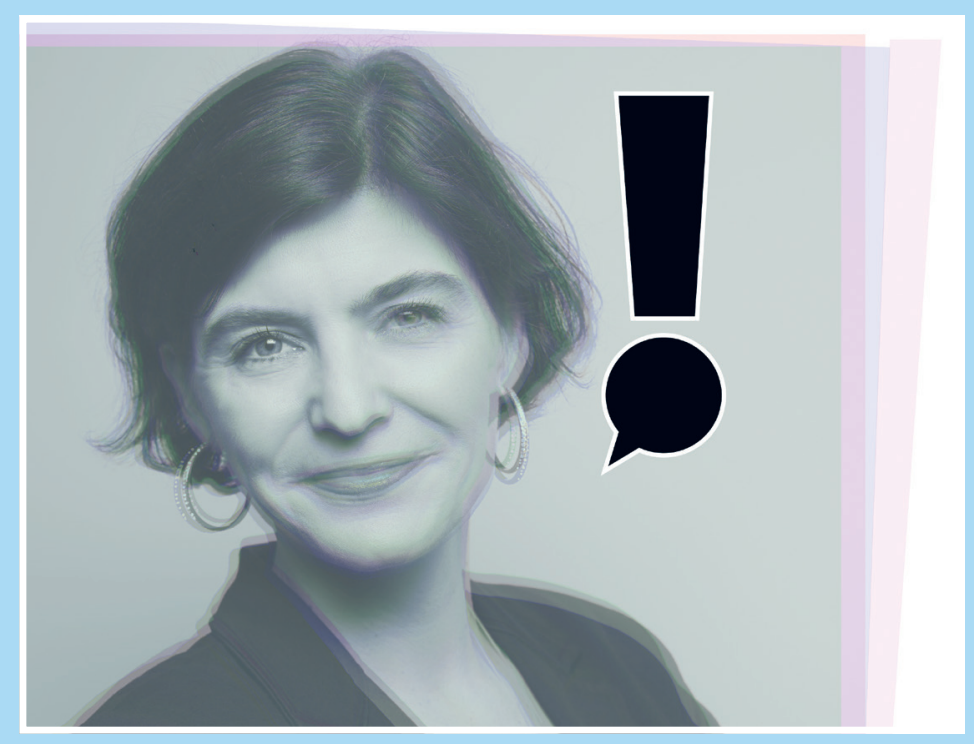

Hvis pressen selv ikke lykkes $\mathbf{i}$ å redigere sine flater, hvis de de facto ikke representerer et nødvendig skille mellom falske nyheter og troverdig informasjon - og hvis redaksjonene heller ikke gjør det mulig for folk å kunne sondre mellom journalistikk og reklame, vil det over tid oppstå et krav om at myndighetene må "gjøre noe".
Journalistikkens hovedoppgave er å bygge oppunder demokratiet. Myndighetene vil regulere pressen, hvis ikke bransjen tar et presseetisk ansvar.

Nå når den profesjonelle journalistikken ikke bare er omgitt av milliarder av små og store digitale publisister med en blogg, en Facebook-konto eller en omfattende mailingliste, men også av netthat, av falske nyheter og av skjult reklame, er det enda vanskeligere enn det har vært de siste 20 årene å holde hodet kaldt og blikket klart når strategien for redaksjonene skal legges.

I all hovedsak har medieverden beveget seg vekk fra de store pengene og de store svarene - til småpenger og granulære løsninger. 
Dette gjelder også svaret på spørsmålet om hvordan det frie, uavhengige ordet kan overleve i en verden som farger alt i ulike grader av grått. Her finnes ikke ett stort svar, men mange nødvendige grep.

\section{Brukeren forventer dialog}

En naturlig forventning er at brukeren tror at journalistikken står for noe spesielt, at man følger en faglig norm. Kanskje kan man sammenligne journalistikk med økologisk mat. Det er ikke sikkert du en gang smaker forskjell, men du vet at fremstillingen er kvalitetssikret etter en etterprøvbar standard.

I møte med journalistikk vil leseren derfor forvente en faglig kontakt med avsenderen. Når "produktløftet" er journalistikk, vil brukeren anta at det finnes en vilje til dialog, til forklaring og redegjørelse. En slik dialog ser vi at stadig flere redaksjoner blir gradvis bedre til.

Noen bygger dialogfunksjonaliteten inn i selve hovedproduktet (som Quartz, qz.com, for eksempel). Andre forklarer publisistiske valg samtidig med kontroversielle saker.

En leser av journalistikk vil også forvente å kunne henvende seg et sted med klager på brudd på den faglige normen. For å kunne kreve å bli trodd må man ha et strukturert system for slike klager. Den som klager må oppfatte at systemet er uavhengig, at det følger retningslinjer, at svaret på en klage er logisk, at det er basert på fornuft og saklig argumentasjon.

\section{Troverdighet og tillitskrise}

Mange redaksjoner synes at de er til å stole på. Undersøkelser om "tillit til mediene" viser at folk likevel ikke gjør det. Det snakkes om en tillitskrise.

For noen redaksjoner vil det å ha en solid merkevare være helt avgjørende. For enda en periode vil det også være nok. Hvis det journalistiske innholdet i økende grad konsumeres på andre plattformer - som i sosiale medier vil merkevarens kraft stå i fare for å viskes ut over tid. I vår hyperinformerte verden, hvem husker hvor man leste eller så hva?

For mange redaksjoner vil den enkelte artikkel og den enkelte publisering være verdienheten i det daglige. Hvordan bygger man troverdighet rundt den?

\section{Presseetikk}

Den profesjonelle journalistikken hevder per definisjon at den står for noe spesielt. Det snakkes gjerne om presseetikk. Hva betyr det for leseren? Hvis reglene er fjernt fra hverdagen, hvis systemet er lite kjent, svakt eller fraværende, hvis ikke alle er tilknyttet det, hvis pressen oppfattes som tøylesløs, da er det vel liten grunn til å tro at referansen til "presseetikk" bygger troverdighet.

Men den kan gjøre det! 
Kjersti Løken

Stavrum: Fravær av

et presseetisk sys-

tem, eller et utilstrek-

kelig system, kan i

verste fall skape et

vakuum for regulering

som myndighetene vil

ha lyst til å fylle, eller

vil føle seg forpliktet

til å gjøre noe med.

Foto: Mogens Blicher

Bjerregård.

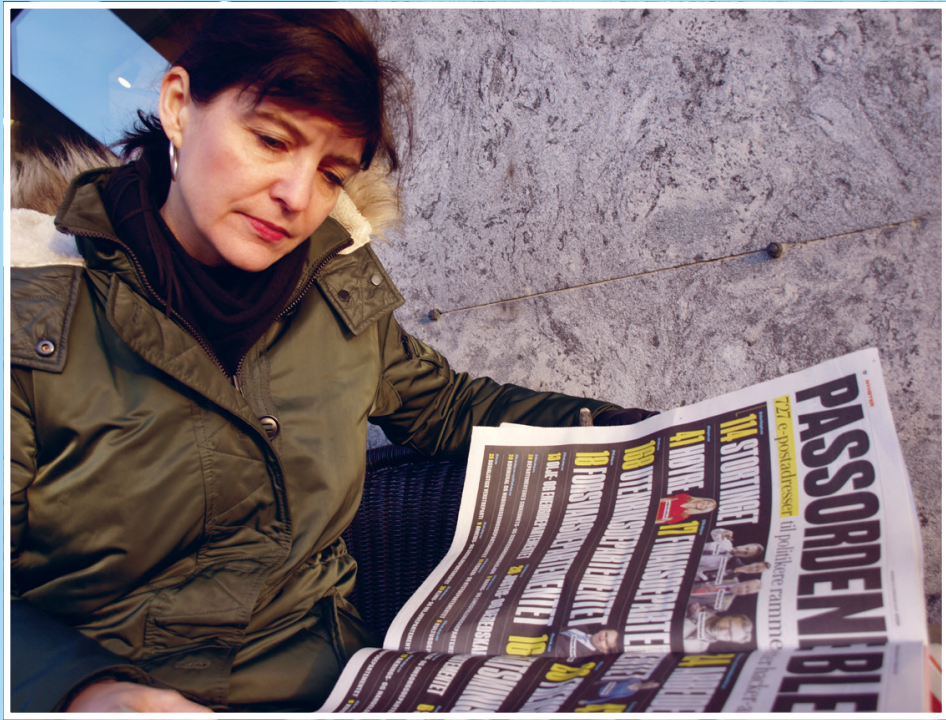

Å redde journalistikken krever at folk har tilstrekkelige åpenbare grunner til å stole på det som står der. Resultatet av dette er lojalitet og kanskje også betalingsvilje.

Konsekvensen er at den offentlige samtalen får et fotfeste, at journalistikken kan brukes slik at argumenter og påstander blir mer enn ubegrunnede følelser og løgnaktige postulater. Sluttproduktet er et demokrati på skinner.

I et mangfold av medier, i et sammensurium av journalister, bloggere, kommentatorer, reklamestemmer, er det vanskelig å se hva som skal skille den troverdige journalistikken fra "alt det andre".

\section{Daglig arbeidsmetodikk}

Å følge presseetiske regler er en daglig arbeidsmetodikk som i det daglige innebærer å gjøre balanserte avveininger mellom hva som har offentlighetens interesse og hva som ikke har det. Det er å sjekke en påstand, å kildebelegge den - og å belyse saken fra flere sider.

Å skille seg fra netthat medfører at redaksjonen sikrer at den som blir angrepet med faktiske anklager får anledning til å svare for seg samtidig.

\section{Et forpliktende presse- etisk system}

Når konflikter tilspisser seg rundt den faglige standarden og hvorvidt den blir fulgt, vil det å være tilknyttet et 
forpliktende presseetisk system om et tydelig kommunisert sett av regler, være et opplagt svar på noe av spørsmålet om hva som kan redde troen på journalistikken.

\section{$\star * *$}

\section{Det må være én presseetisk} plakat, kun ett sett regler

Hvis ulike medier i ett land har forskjellige regler og standarder, vil dette forvirre publikum og undergrave tilliten til ideen om et strukturert arbeid for journalistikk og presseetikk som sådan.

\section{De viktige redaksjonene må være tilknyttet systemet}

Et system kun for de få og marginale, vil få marginal betydning innad og utad.

\section{De store og toneangivende redaksjonene må være tydelig uttalte støttespillere}

En uttalt lojalitet og oppslutning om klageprosessen og en aksept for fellelser er de viktigste markørene for at et system har reell oppslutning og ikke er et skalkeskjul.

\section{Det må være gratis å}

\section{klage på mediene}

Hvis det koster penger å klage, vil bare de ressurssterke kunne bruke det fritt, og alle andre vil vegre seg. Konsekvensene av en betalingsløsning er vakseptable for en fri presse.

\section{Klagesystemet må være raskt}

Tempoet i behandlingen av saker er i økende grad avgjørende ettersom informasjonssamfunnet går raskere. En fellelse av en sak som for lengst er ute av den offentlige debatt, har liten betydning. Sendrektighet vil i seg selv også undergrave tilliten til systemet. Her må man for øvrig være oppmerksom på at begge aktørene i en klageprosess fra tid til annen vil være interessert i å forsinke fremdriften i saksbehandlingen.

\section{Systemet må være transparent} De fleste presseetiske vurderinger er i dag lukket for innsyn. Når det presseetiske utvalg har gjort sine vurderinger, vil man få konklusjonen levert en stund etter at møtet fant sted. Å våge å åpne dørene, å driste seg til å sette et kamera i rommet, vil drive frem uttalte resonnementer og øke forståelsen for konklusjonene.

\section{Alle relevante aktører må være forpliktet av klagesystemet; \\ redaktørene, publisistene og journalistene.}

\section{Troverdighet har en pris}

For redaksjonene må denne prisen betales på flere måter. For å få folk til å tro på påstanden om at journalistikk er noe spesielt, og at den hovedsakelig er til å stole på, må man ikke bare kunne 
vise til at man følger et sett regler i det daglige.

Man må dessuten rette og tydelig beklage når dette er nødvendig, og når man er blitt felt som følge av en klagesak.

Dernest må systemet finansieres for å sikre at det er uavhengig av statlig kontroll. Eller sagt på en annen måte; for å sikre pressefrihet, må bransjen betale det et slikt system koster.

$\varnothing$ konomiske og ressursmessig pressede mediehus vil kunne se det som mindre presserende å engasjere seg i opparbeidelsen av et presseetisk system.

\section{International system for presseetikk}

En annen kompliserende faktor for oppbygging av presseetiske systemer i de enkelte landene, er at mange toneangivende redaksjoner vil oppfatte seg som internasjonale. For Financial Times, for eksempel, som er så grenseløs i sitt publisistiske nedslagsfelt, vil det ikke være så naturlig å støtte oppunder og knytte seg til et britisk klagesystem.

Det samme vil gjelde for flere engelskspråklige publikasjoner, og også franske og spanske.

Er det mulig å se for seg et internasjonalt system for presseetikk som kan bygge troverdighet til ideen om journalistikk på tvers av landegrenser? Tanken kan virke overveldende, selv om vi jo vet at den digitale journalistikken er grense- løs. Og selv om de presseetiske reglene varierer fra land til land, vil man likevel se at de grunnleggende prinsippene ofte er like. Slik sett fortjener tanken å bli modnet og muligheten bør utforskes.

Da Norsk Presseforbund i 2015 åpnet sitt presseetiske system for selvstendige publisister, deriblant bloggere, representerte dette en justering til vår tids medieutvikling. I en periode valgte én enkelt blogger å tilknytte seg plakaten og klagesystemet - i tillegg til de etablerte redaksjonene og mediehusene.

I skrivende stund er ingen slike frittstående del av systemet. Dette fraværet av engasjement fra den nye medieorden kan være et uttrykk for en manglende forståelse for hva strukturert presseetikk innebærer for dem som publiserer.

\section{Myndighetene vil ha lyst til å fylle et vakuum}

Imens vil mengden av informasjon, av journalistikk, av meninger og ytringer stadig øke. Fravær av et presseetisk system, eller et utilstrekkelig system, kan i verste fall skape et vakuum for regulering som myndighetene vil ha lyst til å fylle, eller vil føle seg forpliktet til å gjøre noe med.

Det er særlig tre faktorer som vil påvirke statens engasjement for regulering av pressen: 
- Omfanget av netthat - også utenfor de redigerte mediene

- Omfanget av falske nyheter

- Omfanget av skjult reklame

Hvis pressen selv ikke lykkes i å redigere sine flater, hvis de de facto ikke representerer et nødvendig skille mellom falske nyheter og troverdig informasjon - og hvis redaksjonene heller ikke gjør det mulig for folk å kunne sondre mellom journalistikk og reklame, vil det over tid oppstå et krav om at myndighetene må "gjøre noe".

Trusselen om bøter til Facebook hvis de ikke agerer overfor falske nyheter, slik vi så på nyåret 2017 i Tyskland, et et eksempel på at myndighetene ser seg nødt til å vise handlekraft. Både av hensyn til borgerne, men også for å sikre sin egen posisjon.

\section{Falske nyheter}

Journalistikkens hovedoppgave er å bygge oppunder demokratiet. Hverken falske nyheter, skjult reklame eller hatefulle ytringer er oppfunnet i vår tid. Det nye i vår tid er omfanget og derfor også hvilken fare disse kreftene representerer.

Diskusjonen om hvordan falske nyheter kan bekjempes, og hvordan tillit kan bygges, har tatt fart etter Brexit og Trumps valgseier fordi politikerne så at noe så avgjørende som de demokratiske valg blir påvirket, at man kan miste maktposisjoner av uakseptable årsaker - og at systemet blir truet av feilaktig informasjon.

"Where the press is free and every man able to read, all is safe," sa Thomas Jefferson og satte det hele på plass. Nå er det ikke slik lenger. Pressens frihet og journalistikken må ha en selvstendig ekstraverdi. Den må være være verdt å kjempe for.

Kjersti Løken Stavrum er adm. dir i Stiftelsen Tinius som forvalter den storste eierposten i Schibsted Media Group. Hun har tidligere vært generalsekretær i Norsk Presseforbund og redaktør for og journalist i magasiner, aviser og nettpublikasjoner. Hun er utdannet statsviter og har en mastergrad i ledelse. 


\section{An uphill battle for journalism}

By Kjersti Løken Stavrum (Norway) CEO at the Tinius Foundation at Schibsted Media Group. She is the former secretary general of the Norwegian Press Association.

Social media has transformed freedom of speech from a noble principle to a practicable reality. When everyone is able to publish anything, the concept of professional journalism is blurred and difficult to perceive for the audience.

How to distinguish journalism from all other content? Being accountable and part of a structured system of press ethics can be an opportunity to stand out and communicate a difference for the media business in a future where everyone has a voice, but few know what is worth listening to.

A legitimate, transparent and well structured work for press ethics is now the sole marker for professional journalism and can, if nurtured wisely and complied loyally, provide an answer to several of the core challenges to journalism, including fake news, hate speech and hidden advertising/content marketing. But in many countries the work for press ethics is too marginal, too unknown and has had too little impact for too long.

A trustworthy system for press ethics needs to get all the relevant parties onboard: the publishers, the editors as well as the journalists. To be able to communicate with strength and a clear voice, the editors need to comply with the code of conduct. The complaint system must be free, fast and transparent. That is the judging on the cases must be as open and accessible as possible to the complainants as well as the audience in general.

Establishing a sustainable system for press ethics is probably too late in countries that do not yet have one. To strengthen the system in countries that have one, requires leading media houses and newsrooms to take a prime and strong position in the process.

In the absence of accountable, structured work for press ethics, the need to regulate and discipline hate speech and fake news will force governments to do the job for the press. This will reduce the freedom of the press. 

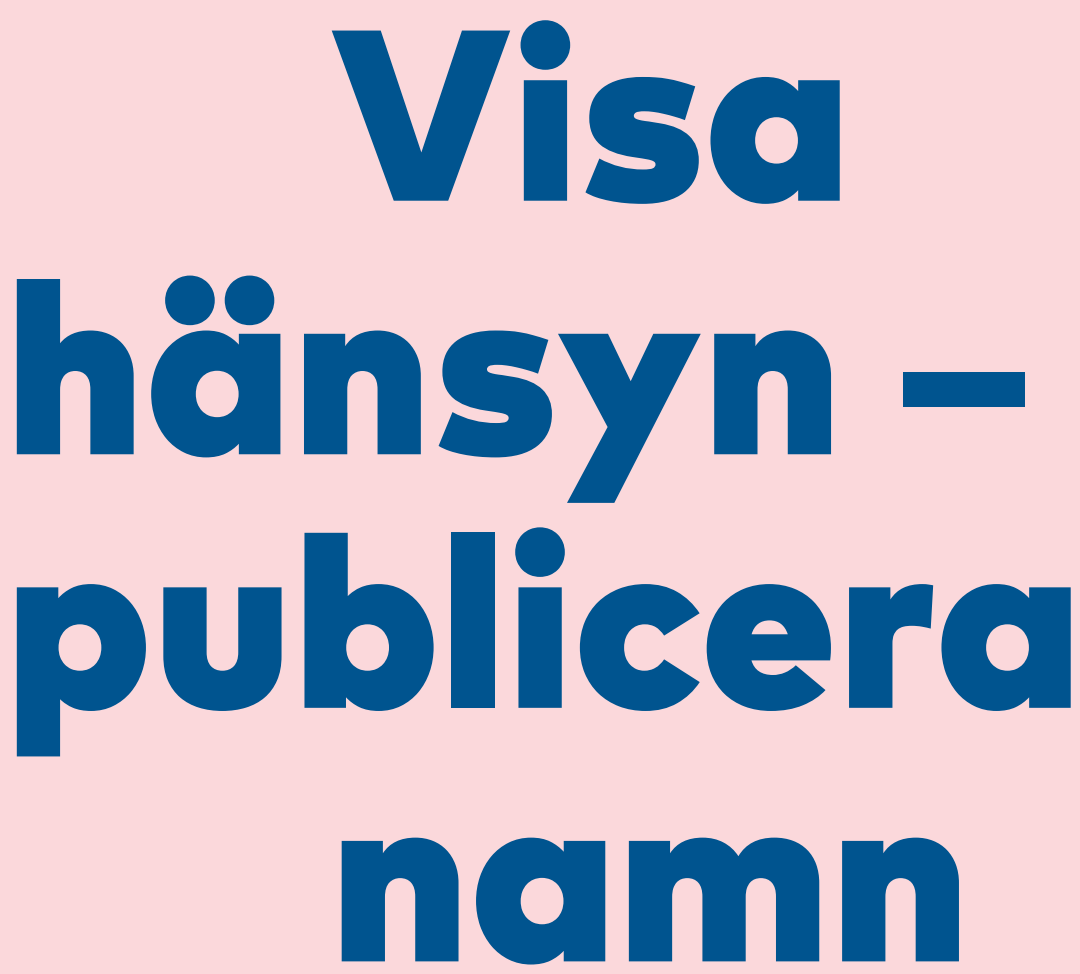

Det finns alltid någon som vet, som känner no̊gon som vet, och vid kaffeborden talas det fritt om det som medierna väljer att tiga om.

\section{Av Astrid Olhagen (Åland)}




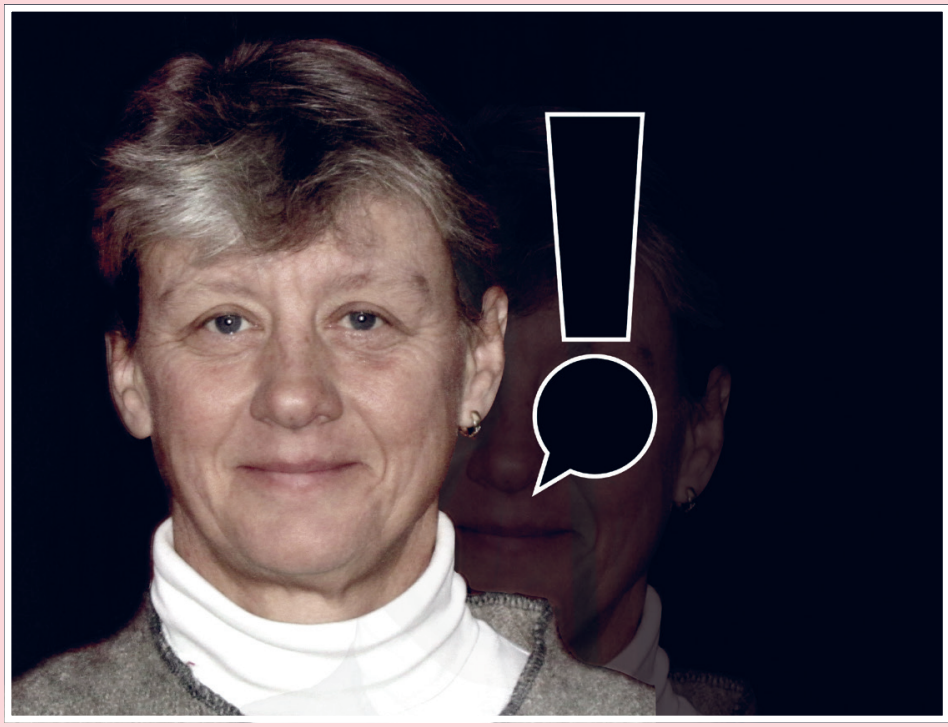

En högt uppsatt tjänstemannen i landskapets Ålands regering var med om en bilolycka med dödlig utgång, långt hemifrån. Hur rapporterar man om detta?

Public service-bolaget Ålands Radio och TV valde att rapportera om olyckan, berätta med namn vem det var som var inblandad samt om den polisutredning som nu pågick som en följd av olyckan. Namnpubliceringsbeslutet var inte självklart och diskuterades ingående på redaktionen, men motiveringen till namnpubliceringen var att personen i fråga var en offentlig person, någon som alla visste vem det var.

\section{Spekulationer}

Tidningen Åland valde att rapportera anonymt om olyckan, och också att spekulera i om huruvida den inblandade ålänningen varit skyldig till olyckan, och en annan trafikants död, genom att göra en oförsiktig omkörning.

Om man inte namnger en person i sin artikel eller sitt inslag är det mycket lättare att släppa iväg sig själv i ogrundade spekulationer eftersom man inte pekar ut någon speciell, utan hela frågan blir mer overklig och teoretisk.

Tjänstemannen hörde i efterhand av sig till Ålands Radio och meddelade att hen inte hade några invändningar mot att vi gått ut med namnet, eftersom vår rapportering i övrigt varit korrekt, men att Ålandstidningens spekulatio- 
ner hade varit mycket sårande, och felaktiga.

\section{Kaffebord och sociala medier}

I ett litet samhälle är det nästan aldrig möjligt att hålla hemligt vem som är inblandad olika händelser. Det finns alltid någon som vet, som känner någon som vet, och vid kaffeborden talas det fritt om det som medierna väljer att tiga om. Därför måste man fråga sig vad det egentligen spelar för roll att medierna väljer att inte publicera namn på de inblandade. Dessutom delas informationen om vem det gäller fritt i olika grupper i de sociala medierna.

Nyheter handlar ofta om personliga tragedier - det finns de som är drabbade, av olycka eller brott, och de som är förövare, eller som av dumhet eller misstag har orsakat en olycka eller katastrof.

Hur ska vi journalistiskt berätta om dessa händelser i ett litet samhälle utan att lämna ut de drabbade eller stigmatisera de misstänkta, och döma dem på förhand. Och hur ska vi hantera deras personliga integritet - ska vi publicera deras namn eller inte?

\section{Pressetiska regler}

Det är en fråga som diskuterades ivrigt på Ålands Radio och TV de 19 år jag var redaktionschef där, och säkert på de flesta redaktionella arbetsplatser alla dagar. Och det är en fråga utan enkla svar. Det man oftast lutar sig mot i diskussioner som dessa är de pressetiska reglerna för namnpublicering:

- Det måste finnas ett oavvisligt allmänintresse för att man ska avslöja vilka personer som döljer sig bakom en händelse som man rapporterar om.

- Det är lägre tröskel för offentliga personers anonymitet.

\section{Oavvisligt allmänintresse}

Ett oavvisligt allmänintresse är det förstås om det rör personer med stor prestige och makt i samhället - kanske en förtroendevald politiker. Eller om det är en för allmänheten okänd person, som sitter på en nyckelpost i just detta avseende - säg en läkare som åker fast för att ha skrivit ut narkotikaklassad medicin till missbrukare.

Den lägre tröskeln för att avslöja offentliga personers anonymitet beror på att de redan är kända och har valt att stå i strålkastarljuset, och därför får finna sig att bli mer granskade. Och för att deras position i samhället ger medborgarna större rätt att få veta om de missbrukar sin makt eller det förtroende de grundar sin position på.

\section{Anonymitet i litet samhälle}

Det finns anledning att fundera över hur anonym någon överhuvudtaget kan 


\section{Varje journalist som skriver om en namngiven person hanterar fakta och verklighet med större försiktighet än om man skriver om någon anonymt.}

vara i ett litet samhälle. Här är Åland med sina knappt 30 o०० innevånare urtypen för samhällen där alla känner alla och där alla har ett stort intresse av att veta VEM det handlar om.

Grundregeln när det gäller publicering av namn i de traditionella medierna är att det är bättre att låta alla vara anonyma, och bara berätta vem som är skyldig/drabbad när det finns särskilda skäl för detta.

\section{Ökad öppenhet}

Ett helt annat förhållningssätt är ökad öppenhet med namnpubliceringar, för det har alltså sina konsekvenser för journalistiken när man publicerar ett namn: man blir mer noggrann att kolla alla fakta innan man publicerar.

Jag anser att namnpublicering är ett sätt att komma ifrån onödiga spekulationer och dåligt underbyggda teoribildningar. Varje journalist som skriver om en namngiven person hanterar fakta och verklighet med större försiktighet än om man skriver om någon anonymt. Anonymiteten här fungerar precis som åt andra hållet, när nättrollen i kraft av sin anonymitet släpper loss sitt ohämmade hat. Det skulle de aldrig göra öppet, om vi visste vilka de var.

\section{Drabbade skapar egen historia}

När det blivit känt vem en historia handlar om träder ofta de skyldiga fram och vill berätta sin version - de skulle säkert allra helst ha velat vara anonyma, men eftersom det är omöjligt väljer de att göra historien till sin egen och berätta öppet om den.

Det finns flera fall här på Åland under de senaste decennierna där de tre lokala medierna valt olika vägar vad det gäller namnpubliceringen av offentliga personer: en kyrkoherde ringde dyra sexsamtal utomlands på församlingens fasta telefon, en ledande moderat politiker med flera förtroendeuppdrag som involverar kontakt med unga människor 
åkte dit för rattfylla, en hög tjänsteman inom det statliga övervakningsorganet för arbetarskydd blev dömd för vanvård av djur, och en av Ålands största nöjesprofiler, tillika tidigare moderat lagtingspolitiker, blev fast för roderfylla. Några åländska medier valde att inte publicera namn i de här fallen, andra att göra det.

\section{Icke offentliga personer}

När det gäller icke offentliga personer finns det större samstämmighet mellan medierna för när man publicerar namn och när man inte gör det. Då finns det också anledning att fundera över vad en namnpublicering kan få för konsekvenser för den enskilde, särskilt om det handlar om unga förstagångsförbrytare.

Även i de här fallen är dock hanteringen av anonymiteten $i$ de sociala medierna utan varje kontroll. Det finns ingen föregående diskussion, inget gemensamt beslut eller analys av varför man ska publicera ett namn. De traditionella publiceringsreglerna är helt satta ur funktion. Därför är det kanske så att det i dag finns större anledning att publicera namn på flera personer också i de journalistiskt producerade nyheterna. För då kan man anta att själva historien också är bättre underbyggd, och att spekulationer och oriktigheter är undanstädade.

Ett annat, ofta framfört, argument för varför man ska publicera vem en nyhet handlar om är att man på så sätt undviker spekulationer och misstänkliggöranden av andra personer än de som faktiskt är inblandade. Det kan göra mycket skada för en fullständigt oskyldig som blir felaktigt misstänkt för att vara inblandad i ett brott.

\section{Tipsares anonymitet}

Trots detta mitt resonemang om större öppenhet och publicering av namn vill jag lyfta fram att det finns några vars anonymitet alltid måste värnas i alla samhällen, och kanske särskilt i ett litet samhälle, och det är tipsarnas. Det kan vara mycket lätt för en företagsledare, eller en chef på en myndighet, att ta reda på vem som har läckt ut informationen om oegentligheter. Det kanske inte finns så många som kan veta hur saker och ting förhåller sig. Här har medierna ett stort ansvar när de tar emot och hanterar tips från personer som kan lida stor skada om deras identitet avslöjas. Men det är en helt annan fråga. 
Astrid Olhagen er finsk og arbetar idag som frilansjournalist. Före det var hon redaktionschef på Ålands Radio och $T V$, världens minsta självständiga public service-bolag, $i 19$ år, och fick där tillfälle att dagligen reflektera över etiska och publicistiska frågeställningar i ett litet samhälle. Till Åland kom hon från Svenska Journalistförbundet i Stockholm där hon i 10 år ansvarade för förbundets internationella arbete och för fackliga och yrkesrelaterade utbildningsfrågor både $i$ Sverige och i världen.

\section{Publish names and show respect}

By Astrid Olhagen (Åland)

Astrid Olhagen, freelance journalist and formerly editor at Åland's radio and television.

A highly positioned civil servant in the government of Åland was in a serious and fatal car crash outside Åland. The media in Åland chose to present this news in different ways.

One media published the name of the civil servant, since it was wellknown in Åland. It also reported about the police investigation that now was conducted as a consequence of the accident.

Another media withheld the information about the identity, but speculated freely about whether the person from Åland had caused the accident by an irresponsible overtaking. This proved to be false, and the civil servant was much upset by the speculation, but not by the publishing of the identity.

Journalists who are reporting about a person identified in the report are more likely to check all the facts, and to do a more thorough research before publishing. They are also more likely to leave out ungrounded speculations from their reports. This is why traditional media should consider if publishing the names of people involved in crime and accidents more often. In particular when it is people who are already well-known to the public in other respects, such as politicians or as powerful businessmen.

In small communities everybody always knows who it concerns. They freely discussed at the coffee tables at every workplace. On social media, there is no limitations on naming the persons involved in the topic of the day. 
"Barn og unge er i dag både aktive mediebrukere og produsenter av innhold i et omfang vi aldri tidligere har sett. Det har på den ene siden stor betydning for den framtidige samtalen, og på den andre siden forplikter det mediene til å lette denne inkluderingen på en etisk forsvarlig måte. Medie- og informasjonskunnskap bidrar dessuten til å gi unge i Norden mulighet for å ta del i den offentlige debatten."

Dagfinn Høybråten (Norge), generalsekretær i Nordisk ministerråd 


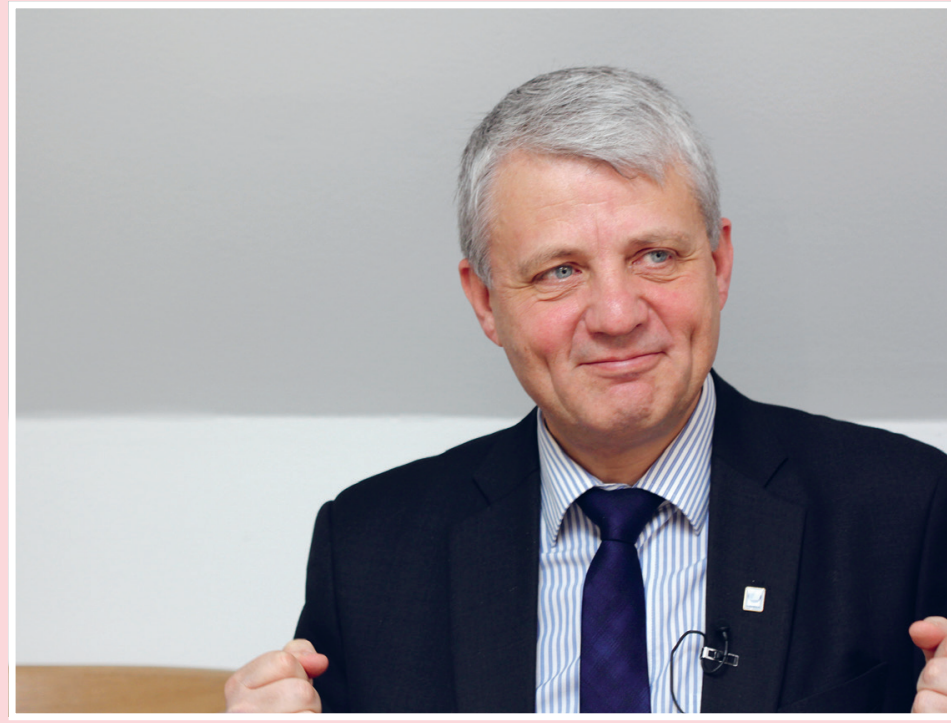

Foto: Norden.org/

Thomas Glahn.

"The youth of today are more active as users and even producers of content in an extent never seen. This has an impact on future dialogue, media literacy and inclusiveness to let the youth take part in the public dialogue." 


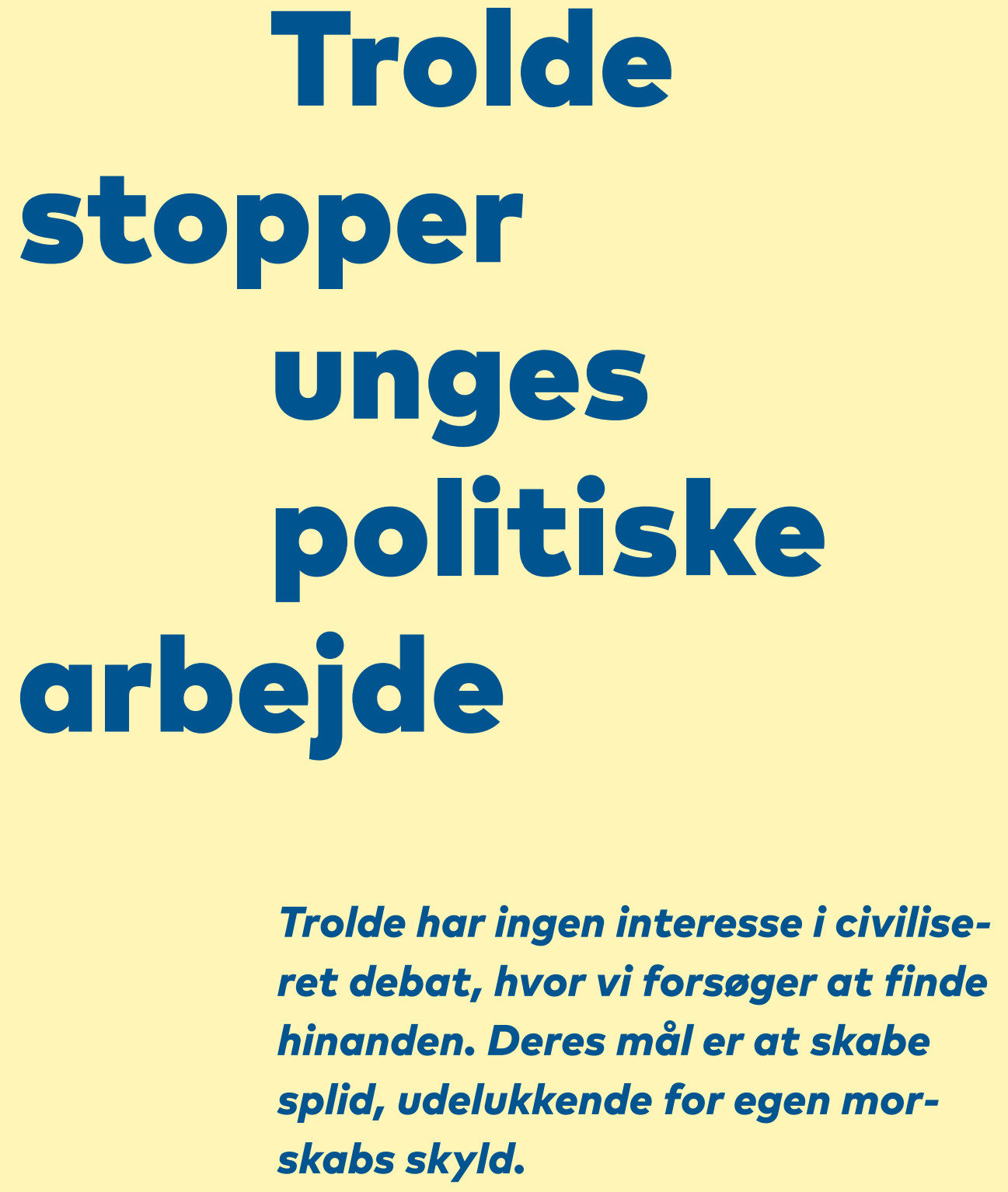

Af Emma Holten (Danmark) 
Emma Holten.

Foto: Levende Menneskerettigheder/ Human Rights in Action.

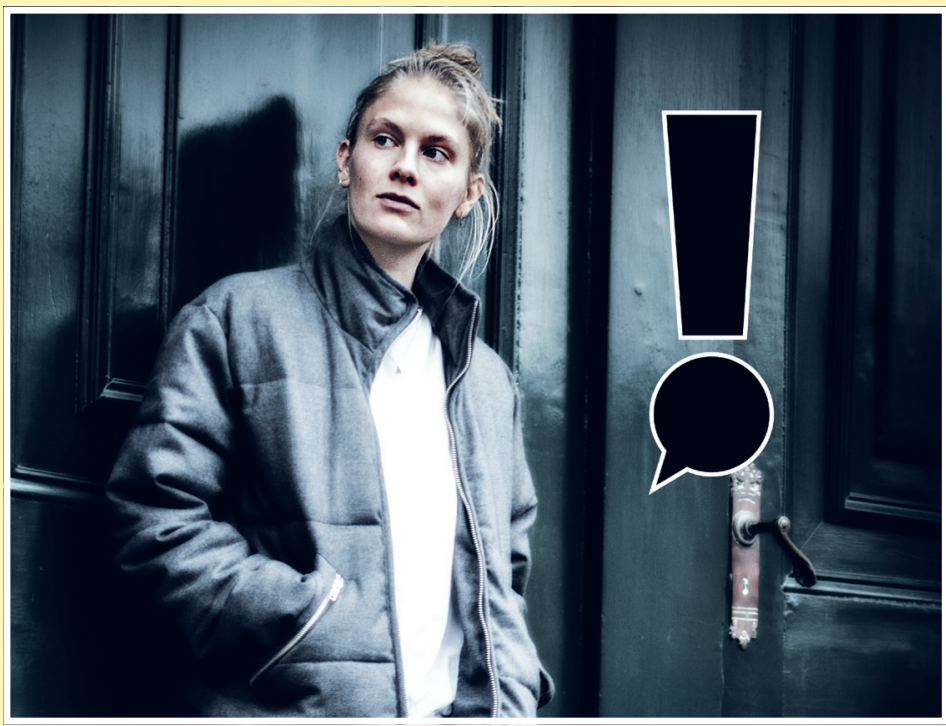

Sociale medier, der ofte hyldes som den nye, demokratiske legeplads, har ikke fået den rolle, man kunne have håbet, siger Emma Holten, som taler politik, internet og etik med unge mennesker.

"Jeg har bare ikke rigtig lyst", sagde hun.

"Hvorfor ikke? Jeg kan da mærke, at du går op i det?", sagde jeg.

"Ja, men det er bare som om, at så snart man begynder at tale om politik, går folk fuldstændig amok".

Udvekslingen foregik på Ungdommens Folkemøde 2016. Temaet for sessionen var "Unges Samfundsen- gagement". For at løsne op mellem oplæggene blev alle deltagere, mest gymnasieelever, bedt om at rejse sig op. I hvert et hjørne af teltet hang et skilt. Der blev stillet et spørgsmål, og så skulle man gå hen til det skilt, der mest repræsenterede ens svar.

Et af de første spørgsmål var: "Diskuterer du politik og samfundsproblemer med dine venner"? Ca. 80 pct. gik over til skiltet "ja, ofte".

Næste spørgsmål var: "Opdaterer du om og/eller diskuterer du politik på sociale medier"? Ca. 80 pct. gik over til skiltet "nej, aldrig".

Der er en åbenlys skævhed her. Noget der ikke helt stemmer. Men når jeg ser på den måde, hvorpå politisk dialog og identitetsskabelse foregår på sociale 
medier, er det egentlig ikke noget, der undrer mig meget.

De sidste 2 år har jeg rejst rundt på gymnasier og talt politik, internet og etik med unge mennesker, og jeg har faktisk fuld forståelse for, hvorfor sociale medier, der ofte hyldes som den nye, demokratiske legeplads, ikke helt har fået den rolle, man kunne have håbet.

For mig er der primært to årsager til, at politisk refleksion og tænkning i de mere private, sociale rum ikke kommer ud i offentligheden, hvor de rykker i debatten. Den første har at gøre med sprog og tale, den anden med, hvordan ytringer og identitet hænger sammen, for dem der er vokset op med sociale medier.

\section{Udstiller og ydmyger}

"Fuldstændig amok", kaldte hun det.

Der er nok få mennesker med en internetforbindelse, der ikke kan nikke bare en smule genkendende til det, hun beskriver. Ude på den yderste flanke har vi, hvad nogle vil kende om "keyboardkrigere" eller "trolde". De, som tænder deres computer, tørstige efter et skænderi, efter at kunne udstille og ydmyge folk. Ordet er blevet så accepteret, at det nu har en lang og grundig wikipedia-artikel:

"... a troll is a person who sows discord on the internet by starting arguments or upsetting people, by posting inflammatory, extraneous, or off-topic messages in an online community ... with the intent of provoking readers into an emotional response or otherwise disrupting normal, on-topic discussion, often for the troll's amusement."

Sagt på dansk: En trold er én, der går i byen for at slås.

\section{Trolde - sjov eller alvor?}

Trolde kan virke relativt harmløse i denne beskrivelse, men ligesom den voldsglade bodegagæst har de ofte en langt større effekt, end bare en reaktion fra den, de angriber: De ændrer samtalen og rummets natur.

Når en person pludselig ikke har noget investeret i hverken det politiske emne eller ordentlig omgang med andre, går det stærkt ned ad bakke.

Ingen er længere klar over, om samtalen er alvorlig eller ej, om det her er et sted, hvor man er nødt til at opføre sig ordentligt, for ingen kan se, hvad der er for sjov og hvad der ikke er. For folk der er ukendte med troldenes ofte grove og ødelæggende facon, bliver reaktionen oftest at samtalen meget hurtigt ender, eller fuldstændigt afspores.

Men troldemetoder er - selvfølgelig - heller ikke apolitiske, ligesom de heller ikke er harmløse.

Trolde søger at nedbryde sober samtale og lukke munden på mennesker der, som de siger, "ikke kan klare mosten". Og effekten udebliver ikke. 
Både New York Magazine, Esquire og Washington Post udgav i kølvandet på Donald Trumps sejr artikler med titler som "How internet trolls won the 2016 presidential election" og "The only true winners of this election are trolls".

\section{Trolde ønsker kaos og splid}

Trolde har ingen interesse i civiliseret debat, hvor vi forsøger at finde hinanden. Deres mål er at skabe splid, udelukkende for egen morskabs skyld. De skyr ikke personangreb som f.eks. at kalde andre mennesker navne, photoshoppe billeder af dem, de diskutere med, eller at chikanere folk gennem kommentarer og beskeder. Deres navn er: Kaos.

Det er højst sandsynlig disse mennesker, den unge kvinde i teltet henviste til. Og der er slet ingen tvivl: Ligegyldigt hvor hårdhudet du er, er det utroligt ubehageligt ikke at blive respekteret og hørt.

\section{Frasorterer de følsomme}

Troldes kritik (ja, nogle gange organiserer de sig i forsøget på at artikulere en position) er at befolkningen er blevet for blød. At fokus på emner som racistiske, sexistiske og homofobiske ord, har opdraget en generation af "snefnug", der ikke kan klare kritik.

Deres mål er at frasortere dem, de mener er for følsomme. Den unge, politisk interesserede kvindes udeblivelse er en følgeskade af disse taktikker. Det er ikke engang sikkert, at hun selv har oplevet det på egen krop. At observere andre blive udsat for det, er rigeligt.

Det kræver desværre kun én eller to at forpeste et kommentarfelt. Specielt for den, der rammes. Jeg kan personligt vidne om, at hjernen desværre ikke er rationel her. I en sø af gode kommentarer vil den negative stikke ud som en torn. Og det er den, der gør, at man næste gang tænker "nej tak".

\section{Det kræver desværre kun én eller to at}

forpeste et kommentarfelt. Specielt for den, der rammes. Jeg kan personligt vidne om, at hjernen desværre ikke er rationel her. I en sø af gode kommentarer vil den negative stikke ud som en torn. 


\section{Ofte vil personer uden en akademisk uddannelse ikke have en jordisk chance, og unge i gymnasiealderen kan i hvert fald slet ikke være med.}

\section{De bedrevidende}

En anden gruppe, der ikke er lige så bevidst ondsindet, men kan have lige så stærk effekt på debatten, er de meget erfarne onlinedebattører. Mennesker, der bruger meget (meget!) tid på at debattere politiske emner på nettet. De ser en sport i at finde et hul i argumentet og udstille den andens uvidenhed. De vil vinde. Have det sidste ord.

Det kræver en helt enorm viden, tålmodighed og erfaring at kunne deltage i samtaler med dem. Det her er det, de gør.

\section{Fældet af målestokken}

Du vil finde dem under enhver opdatering, der falder ind i deres interesseområde. De er ikke som sådan ubehagelige eller nedladende. De er bare mennesker, der giver et indtryk af, hvad man som minimum skal være i stand til, for at ytre sig politisk på internettet. Det er ikke nok at komme f.eks. med personligt input, med en tanke eller noget, man har gået og reflekteret over.

Alt skal bakkes op med statistik, og gerne en forsker eller en filosof. Det er aviskrav til samtale. Misforstå mig ikke: Ingen bestrider at lødighed hører til i debat. Men disse krav gør henkastede, hverdagslige samtaler om politik, om samfundsnormer og personlige erfaringer til noget, der knap kan eksistere i den politiske arena.

Effekten bliver sjældent, at folk går ud og ruster sig med grafer og citater af Michel Foucault. Tværtimod trækker de sig tilbage. Ofte vil personer uden en akademisk uddannelse ikke have en jordisk chance, og unge i gymnasiealderen kan i hvert fald slet ikke være med. Den uddannede, velformulerede person bliver målestokken for alt.

\section{Samtalen forsvinder}

Deres personlige erfaringer bliver hele befolkningens erfaringer, og deres blik på verden bliver ikke bare det politiske, men det hverdagslige. Der er meget få politiske rum på facebook, hvor man blot kan ytre undren, lære eller forsøge at forstå bedre. Politisk samtale er ikke rigtig noget, der eksisterer. Debat er modus operandi, når vi snakker om politik. 
En stor del af dette er, at hele kropsligheden ved politisk samtale er væk. Alle de høflighedsfraser, nik, smil og gestikulationer, der blødgør gnidninger i debatter, er væk. Råt for usødet er nu kun argumentet tilbage.

Det gør den politiske menu næsten uspiselig for dem, der foretrækker en smule menneskelighed serveret med sin politiske samtale. Antallet af kloge, sjove, vidende mennesker, der er faldet fra pga. af disse forhold, er et umålbart tab. Jeg møder dem hver eneste dag.

\section{Profilen som prisme}

Det er et meget specifikt liv, man lever, når man er vokset op med internettet. For dem, som fik internettet sent i livet, er det som en gevækst på en allerede eksisterende identitet. Der var et navn, en krop og et liv, inden der var en profil.

Sådan fungerer det ikke for dem, der har haft en tilstedeværelse på sociale medier hele deres bevidste liv. Her er "profilen" som et prisme hvorigennem hele ens menneskelighed ses.

Det, der deles her, er ikke bare et sjovt link eller en strøtanke, men i høj grad en gennemtænkt del af et kurateret selv. Ikke fordi de unge er mere selvoptagne end andre, men simpelthen fordi det er sådan, profilen læses af deres omverden.

I denne dynamik passer politisk bevidsthed og aktivisme meget dårligt. Ikke fordi det ikke er muligt at have en politisk identitet, men fordi det er meget svært at kontrollere, hvilke konsekvenser en politisk ytring vil have, og hvilke reaktioner, den vil afføde. At ytre sig politisk i det offentlige rum er at gamble med sin identitet.

\section{Politik bliver for socialt risikabelt}

For dem, der er engagerede i f.eks. ungdomspolitik, er det selvfølgelig oplagt at ytre sig, men for de "læg-unge" - dem der bare observerer og er i verden,

\section{Du aner ikke, hvem der læser med og hvad de tænker. Du aner ikke, hvornår det vil blive fundet frem igen og måske brugt imod dig. Det kan være i morgen, det kan være om fem år.}


befolkningen - er politisk stillingtagen og refleksion ikke en særlig attråværdig måde at fremstille sig selv på. Det er simpelthen for socialt risikabelt.

Du skal være ekstremt politisk passioneret, hvis du mener, at det er en chance, der er værd at tage. Frem for alt skal du være skråsikker.

Du skal være overbevist om at du har ret og de andre tager fejl. Denne skråsikkerhed, denne vilje til at integrere et politisk ståsted ind $i$, hvordan du opfattes af andre, er en hjørnesten i den unge person, der deltager og bekender kulør på nettet.

Det er et forfærdeligt udgangspunkt. Det skaber enklaver, hvor man opsøger og taler med dem, der bekræfter ens holdninger. Frygten for at blive "afsløret" i at tage fejl, overskygger klart ønsket om at overbevise andre, eller selv blive klogere. At skifte politisk holdning er ikke rigtig en mulighed, hvis du siden du var 15 har profileret dig på en speciel måde og med stor sikkerhed. Det her helt forståeligt, at mange ikke orker eller tør tage den chance.

\section{At "passe ind"}

En speciel risikogruppe er de, hvis liv er eksplicit politisk. De, der rammes af f.eks. racisme, fattigdom eller homofobi, har meget lidt at vinde på at yderligere lede opmærksomheden hen på de politiske faktorer, som gør dem anderledes end andre. Den drivende kraft i ungdomslivet har altid været at passe ind, og denne kraft er ikke blevet svagere med internettet - tværtimod.

At politisere sin hverdag er en måde at skille sig ud i en tid, hvor det ofte er det sidste, man har lyst til. Det gør dig åben for angreb fra et utal af sider, du ikke kender til. Det bliver endnu en volatil faktor i et hverdagsliv, der er svært nok i forvejen.

De unge, der ved, at livet er langt og politik er svært og komplekst, vil sjældent være dem, der snakker om politik på nettet. Det er et stort tab for debatten.

\section{Ytringsfrihed i kulturel forståelse}

Ingen af disse problemer kan løses med lovgivning. Der er ikke nogen af dem, du har læst om i denne tekst, der skal forbydes at tale ved lov eller trussel.

Det handler om ytringsfrihed i den kulturelle forstand, om hvilke dynamikker, der gør, at nogen helt enkelt vælger den offentlige ytring fra.

Kun kultur og socialt arbejde med etik og digital dannelse kan gøre forskellen her. Det handler om en refleksion over, hvad præmisserne er for politisk debat i dag. Hvordan det politiske binder sig til vores hverdagsliv, og hvordan hverdagslivet pustes ind $\mathrm{i}$ politikken igen.

Internettet blev hyldet som en revolution af den offentlige samtale. Det har det også været på mange måder. Men der er langt igen, før vi alle taler på lige fod og med lige stor respekt. 
Emma Holten er feminist og menneskerettighedsaktivist. Hun er medstifter og redaktør på det normkritiske magasin Friktion og desuden studerende ved Københavns Universitet. Hun udtaler sig i både nationale og globale sammenhænge om feminisme, digital aktivisme og hvorfor privatliv på internettet er altafgørende for et demokrati, hvor alle er lige.

\section{Trolls prevent the young from participating in politics}

$4 R$

\section{By Emma Holten (Denmark)}

Emma Holten is a feminist, human rights activist, and a reknown debater in Denmark.

In the beginning, the internet was praised. Now, finally, we would have the democratic sphere that would set off true debate. The most reasoned and thorough argument would reach the top, and everyone, on every rung of society's ladder, could be the one making that argument!

Alas, 20 years later, the excited clamour has all but ceased. Increasingly, young people opt out of political debate online. Why? In my view, two main factors are responsible. Troll culture is the first. People with a knack for chaos have always existed.

But now, these people are wreaking havoc in every conversation, and the effect is swift: confusion and fear are the immediate consequences. Why risk engaging in a conversation, spending time to reflect and understand, if you can never be sure if the thread will be bombarded with hate or derailment? A meaningful conversation depends on an agreement on the terms, if someone treats it as a joke, everyone who takes it seriously will disengage.

The second reason is the ways in which online profiles are tied up with actual identity. Engaging politically is a very risky public move. Before, one could move between different spheres in life, maybe test out different thoughts and views. Now, a political utterance is forever tied to you as a person. The space to change your mind or admit defeat is slim. To many young people, the rewards for engaging politically are simply not worth the risk.

The result is a loss for democracy and for all of us. The debate becomes a space for those who have no doubt, no sensitivity, and even less a wish to learn. An increase in polarisation is the immediate consequence, the long term ones are much scarier and difficult to predict. 

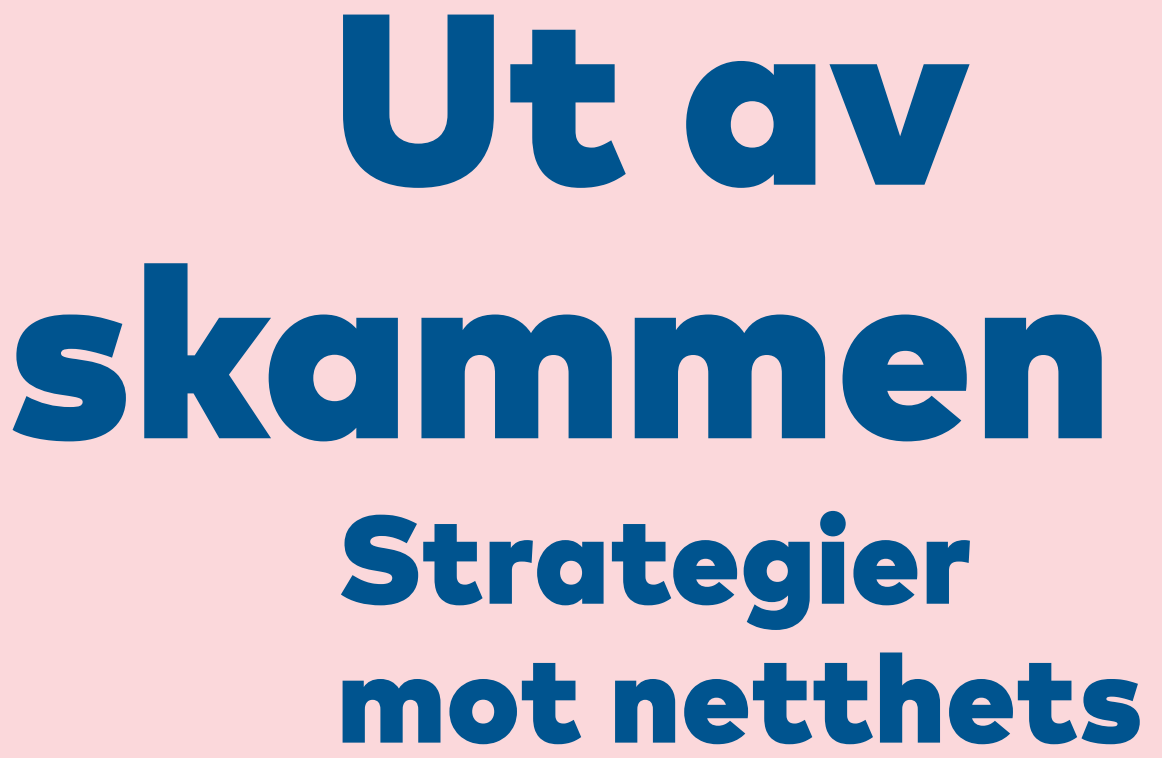

Netthets kommer i mange former, men den har en ting felles: En forventning om at mottageren ikke vil gjøre motstand. Men ikke alle lar seg kneble.

Av Aina Landsverk Hagen (Norge) 
Aina Landsverk Hagen.

Foto: Katrine A. Ziesler.

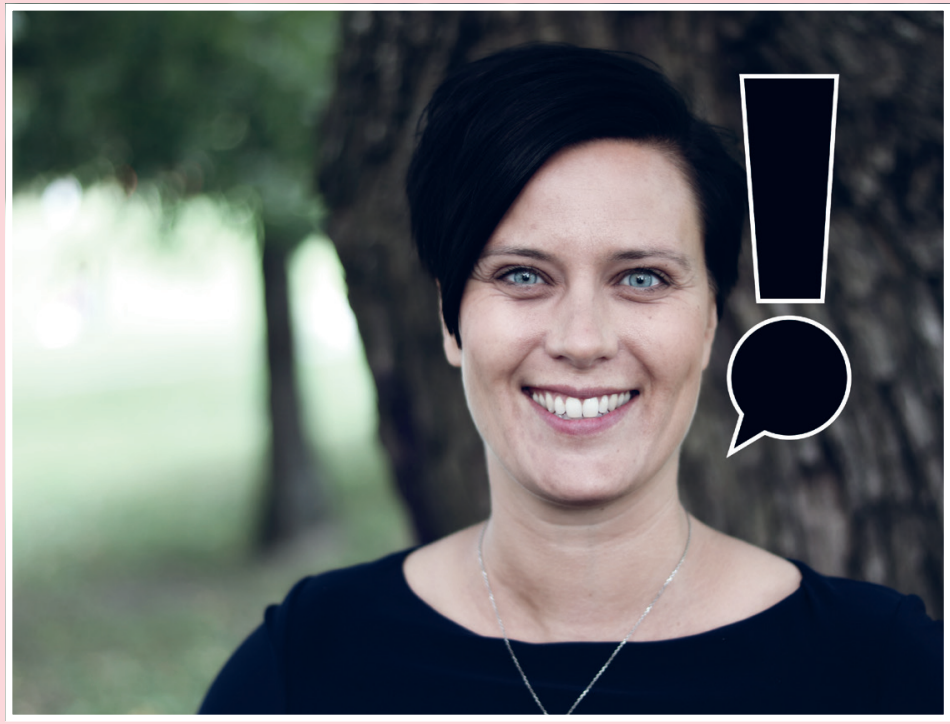

\section{Del 1: Fenomenet}

\section{Motstandsstrategier}

"Hadde jeg vært deg, hadde jeg vært jævlig forsiktig med å spre det". Når Noora i tv-serien Skam lekser opp for Nicolai alle lovbruddene han har gjort seg delaktig i ved å ta bilder av henne naken, uten samtykke, og så spre dem på nett, er det en aktiv motstandsstrategi hun bruker.

Nooras tordentale viser til den norske straffeloven - nå §311, og handler om det som kalles hevnporno. Hun velger en strategi som snur situasjonen, fra at hun er offer og han overgriper, til å vise tydelig for omverden at skammen den er hans, ikke hennes.
Ta igjen er én motstandsstrategi flere unge debattanter og bloggere anbefaler, når jeg har intervjuet dem om hvordan det er å bli hetset og truet på nett, for meningene dine eller bare fordi du er den du er. Andre strategier er å dokumentere, finne et fellesskap, ignorere eller anmelde - dersom det er snakk om et lovbrudd. Men bør man ikke tåle litt hets, hvorfor er det så ille?

\section{Opplevelsen og sjokket}

De jeg har intervjuet forteller alle om første gang de opplevde å bli hetset - for noen var det svært alvorlig med åpenbare draps- og voldtektstrusler, for andre er det mildere former for hets 
som beskrives, den som går på utseende, alder, yrke eller temaer du skriver og ytrer deg om.

For mange er det en blandet opplevelse, av at respons kan være positivt - i starten, før det utarter seg og blir "rart". Når komplimenter blir til utprøvende eller aggressiv stalking eller trusler om vold eller voldtekt.

"Jeg tror først helt i begynnelsen, det første jeg tenkte var at dette her kan jo ikke være riktig, dette må være sendt til feil person (...) etter hvert når det kom flere og flere så skjønte jeg at dette er rettet mot meg, og etter hvert så bygget det seg opp." Kvinne, minoritet, debattant, tidlig tjueårene

Felles for dem er at de beskriver det som et sjokk, noe de ikke var forberedt på, noe som ble ensomt, og hvor reaksjonen deres i etterkant var avhengig av hvordan andre rundt dem håndterte situasjonen.

Ble de latterliggjort, ignorert, overlatt til seg selv eller tok venner, sjefen eller kollegaer ansvar - det ser ut til å ha stor betydning for hvordan senere episoder av sjikane oppleves og håndteres, og hvorvidt dette er noe man forteller andre dersom det skjer igjen - og igjen - og igjen.

\section{I alle kanaler samtidig}

I undersøkelsen som resulterte i boken Meningers mot: Netthat og ytringsfrihet i Norge (2015) kommer det fram at nær halvparten av norske journalister de siste fem årene oppgir å ha erfaring fra sjikane, trusler eller vold. Sammenlignet med den øvrige befolkningen opplever norske journalister og redaktører å få mer hets og trusler i forbindelse med publisering. Det er like mange kvinnelige journalister som mannlige som opplever hets, men noen flere menn som mottar trusler.

Framveksten av sosiale medier, nettbaserte diskusjonsforum og kommentarfelt i nettaviser har ikke skapt, men synliggjort det vi kaller netthets, netthat, nettmobbing, hatytringer eller hatprat.

Det har også forsterket opplevelsen av at slik hetsing er massiv fordi den kommer i "alle" kanaler samtidig. Sjikanen norske journalister og redaktører får i etterkant av publisering kan handle om alt fra sinte eposter om hvor dumme de (eller sakene deres) er til beskyldninger om å være hore eller ond, trusler om drap, vold eller voldtekt, og i noen få tilfeller faktiske voldsepisoder.

Det er ofte en gråsone mellom hets og trusler på nett, der man bruker mye energi på å forsøke å tolke budskapet. Bildet som kommer fram både blant ungdommer, og blant journalistene og bloggerne jeg har snakket med, er at det er liten sosial kontroll på nett. Dette gjør det vanskelig å vite hva som er 
greit, hva som er lovlig hets, men ikke greit og når man faktisk har blitt utsatt for noe ulovlig.

\section{Hvem kan lovverket?}

Det er ikke bare ungdom som ikke vet hva som er straffbart å gjøre på nettet. Det er hva vi kan kalle et legalt tomrom i sosiale medier, der også voksne hetser og truer uten å være klar over, eller bry seg om at det er straffbart.

Rapporten Tull eller trussel? er helt tydelig på at det må gode systemer til for å forebygge og bekjempe hatkriminalitet på nett. Ungdommene selv sier de trenger kunnskap om skadevirkningene av en aggressiv sjargong på nett, og informasjon om konsekvenser av lovbrudd. De mener dette er mer effektivt enn ren kunnskap om lover og regler.

Det er også viktig for dem at voksnes kompetanse om ungdoms digitale univers styrkes.

Ungdom i Oslo er på Facebook tre timer om dagen i gjennomsnitt, ifølge Ungdata-undersøkelsen, nettet er gjennomgripende i deres sosiale dagligliv.

Spesielt vil ungdom at voksne skal forstå hvordan og hvorfor ungdom tar risiko på nettet, samt konsekvenser av anonymitet og liten grad av sosial kontroll på nettet. I sum er det ifølge ungdommene "de voksne som trenger opplæring", men i dag finnes det ikke noe systematisk opplegg rundt dette, verken på arbeidsplasser, i skolen eller politiet.

Fordi sjikanen ikke bare er nettbasert, men også kommer gjennom verbale eller fysiske konfrontasjoner, kan begrepet netthets i noen grad være med på å skjule hele spekteret av sjikane og trusler som mange meningsytrere utsettes for. Noe av det som har vært synset mye rundt, men forsket lite på, er hva netthets gjør med mottagerne.

\section{Del 2: Konsekvenser}

\section{Knebling og ytringsskader}

Sjokket over å bli møtt med hets eller trusler, fører til det filosofen Judith Butler kaller ytringsskader. Begrepet sier noe om hvordan det å bli utsatt for hatytringer gjør at mottageren kan miste fotfestet, og kvie seg før hun mener noe igjen.

"... følelsesmessig så er det ikke bare frykt det spiller på, men også sjelefreden og også selvtilliten du har. Hver gang jeg åpnet munnen min, så begynte jeg å stille spørsmål til meg selv om at jeg ikke var god nok til å prate om dette her."

Kvinne, minoritet, debattant, tidlig tjueårene 
En femtedel av norske journalister og redaktører oppgir at de føler seg kneblet på grunn av hets. Det er ifølge Butler det uventede ved språkhandlingen som er så virksomt.

Man blir satt på plass. Problemet er bare at denne plassen, dette stedet, kan være et ingensteds. Du blir ikke bedt om å pelle deg tilbake til kjøkkenbenken. Du blir bedt om å ikke være det du er, der du er det. Dette er et vanskelig felt, for det er som en av redaktørene jeg intervjuet sier: "Det er ikke objektivt, det er ekstremt subjektivt - følelsen av ubehag er ekstremt subjektiv".

\section{"Det gjør at man vurderer noen} ganger å legge fra seg de sakene man vet at nå kommer det til å komme masse dritt, og så velger man heller de sakene som er litt ufarlige. (....) Så, det er hele tiden en vurdering om det er verdt det eller ikke, om det er viktig å få ut feminisme, om det er det viktigste. Og det er viktig for meg å få fremmet den saken, men hvor viktig er det i forhold til min egen helse?"

Kvinne, midten av tjueårene, feministisk blogger, aktivist

Selvtilliten, troen på at det vi sier, mener og jobber for, gjør en forskjell i verden, er avgjørende for at vi skal klare å være meningsbærere i offentligheten. Nettet legger til rette for at vi får spredd meningene våre, knytte nettverk og operere uten portvoktere. Samtidig er det lett å glemme at teknologi aldri er nøytralt.

Vi vet fra psykologisk forskning at det er noen faktorer ved nettet som gjør at vi oppfører oss annerledes der enn vi ville gjort i en ikke-digital sosial situasjon, der vi er ansikt til ansikt: muligheten for anonymitet og arkivering (ytringer forsvinner ikke lett fra nett), tilgjengeligheten, det er overkommelig, hetseren sitter ofte alene og møter ofte aksept fra andre.

Nettet er et rom som (foreløpig) mangler sosial kontroll. Dette forklarer, men forsvarer ikke kjipe handlinger. Det gjør oss eller de andre ikke til onde folk, men forklarer både hvorfor ungdommer truer hverandre og kaller det bare tull, eller hvorfor Nicolai tror han kommer unna med å sende nakenbilder av Noora rundt til venner. I grunn er det bare gamle hersketeknikker i ny drakt, som igjen kan føre til knebling av nye stemmer i offentligheten.

"Også begrenser det meg sånn at jeg ikke klarer å skrive, for jeg får en slags sperre, og det er den største nedturen med dette her, at jeg føler at jeg begrenser mitt potensiale så utrolig mye (...) Jeg føler at kanskje det jeg skriver 
ikke er bra nok. Det er allerede utfordrende nok å være 21 år gammel og ha en solid stemme i det norske samfunnet." Kvinne, minoritet, debattant, tidlig tjueårene

\section{Del 3: Strategier}

\section{Nett-sensitivitet}

Når vi vet at opplevelsen av å motta hets eller trusler på nett, er subjektiv og situasjonsbestemt, er det heller ikke bare én strategi som fungerer. Derfor kan det være en god idé å heller utvikle et sett av strategier, som en del av en ekstra sensitivitet på nett. Sammen med kunnskap om effekter av hets, hva det gjør med folk, og konsekvenser av å bryte loven, gir det oss nye muligheter for digital grensesetting. Men hvem har ansvaret for å utvikle slike strategier er det den som blir netthetset?

"Etter min mening er det en ganske alvorlig greie for demokratiet, for det gjør jo rett og slett at man mister stemmer (...) samtidig så er det ganske reelt å føle på et ubehag, fordi det er tross alt frivillig å skulle uttale seg i offentligheten. Hvis du syns det er kjempeubehagelig så kan du velge det vekk. Problemet er bare at når så mange kvinner velger det vekk, til slutt så har du ikke en reell ytringsfrihet, og da er jo det noe myndighetene faktisk må gå inn og arbeide med, fordi ja - det er ganske alvorlig." Kvinne, midten av tjueårene, feministisk blogger, aktivist

\section{Fellesskap og rollemodeller}

En av motstandsstrategiene som går igjen, blant både unge debattanter og erfarne journalister, er å finne andre som har opplevd noe lignende. Det reduserer skammen, å oppleve at man ikke er alene, at man er normal når man reagerer med sjokk, vemmelse, frykt eller sinne.

"... følelsen av å stå alene, den er litt uunngåelig, tror jeg, fordi det er veldig vanskelig å forklare alle de tingene her. Mange av de tingene som oppleves som ubehagelige er vanskelige og uhåndgripelige. De er vanskelige å peke på, de er ikke så konkrete, de er bare en følelse av å bli latterliggjort, og det er litt vanskelig å forklare folk ..." Kvinne, midten av tjueårene, feministisk blogger, aktivist 
Det har altfor lenge vært den individuelle mottageren av hets og trusler på nett sitt ansvar å håndtere dette. Det er på høy tid at myndigheter, teknologibedrifter, arbeidsgiver, redaktører og skoleledelse ser sitt ansvar og både jobber bedre forebyggende og med oppfølging. Skammen er, som Noora har skjønt, nemlig ikke din å eie, den tilhører de som forsøker å kneble deg og ta fra deg din ytringsfrihet.
Aina Landsverk Hagen er seniorforsker ved Arbeidsforskningsinstituttet og sosialantropolog med doktorgrad fra Universitetet i Oslo. Hagen publiserte nylig debattboken Meningers mot: Netthat og ytringsfrihet i Norge (2015), basert på en omfangsanalyse av sjikane og trusler rettet mot organiserte journalister og redaktører $i$ Norge. Hun har deltatt $i$ OSCEs ekspertpanel om hatytringer mot journalister og innledet på flere av Nordisk ministerråds konferanser om sexisme, hatytringer og ytringsfrihet.

\section{, 4 政}

\section{No more shaming: Strategies against online harassment}

By Aina Landsverk Hagen (Norway)

Aina Landsverk Hagen is a senior researcher and social anthropologist at the Work Research Institute at the University College of Oslo and Akershus.

Online harassment comes in many shapes and forms, but have one thing in common: An expectation that the receiver will not resist.

But gagging is not for everyone to endure. From interviews and surveys on the topic a set of resistance strategies towards harassment and threats emerge. One of them is to strike back, to turn the shame of being a victim to shaming the perpetrator.
The legal knowledge on countering various forms of online harassment, is crucial here.

Other widely used strategies are to document the harassment as a way of feeling more secure, finding a community of people that support and understand the stress caused by online harassment.

For some it is a strategy to ignore it all together. For others we will find it limits the emotional strain to press charges - depending on the severity of the harassment.

Bloggers, debaters, activists, journalists and editors in Norway talked about the harassment they experienced the first time, and the common denom- 
inator is the shock, the loneliness and the dependence on people supporting your subjective perception of the situation. This is what Judith Butler calls speech injuries: When we are so shaken by the surprising experience of being exposed to hatred, that we alter our public opinions or refrain from discussing certain topics in the public sphere. To prevent speech injuries is one of the most important tasks of a democracy.

It is easy to forget that digital technology is not neutral, its charac- teristics are influencing our actions and the ability to empathize. It is for the moment a normless sphere, where sanctions against hate speech, harassment and threats are yet to have the same impact as in physical life. The responsibility to prevent and tackle online harassment and threats should fall on authorities, employers, technology companies and editors, not on individuals who are harassed. 

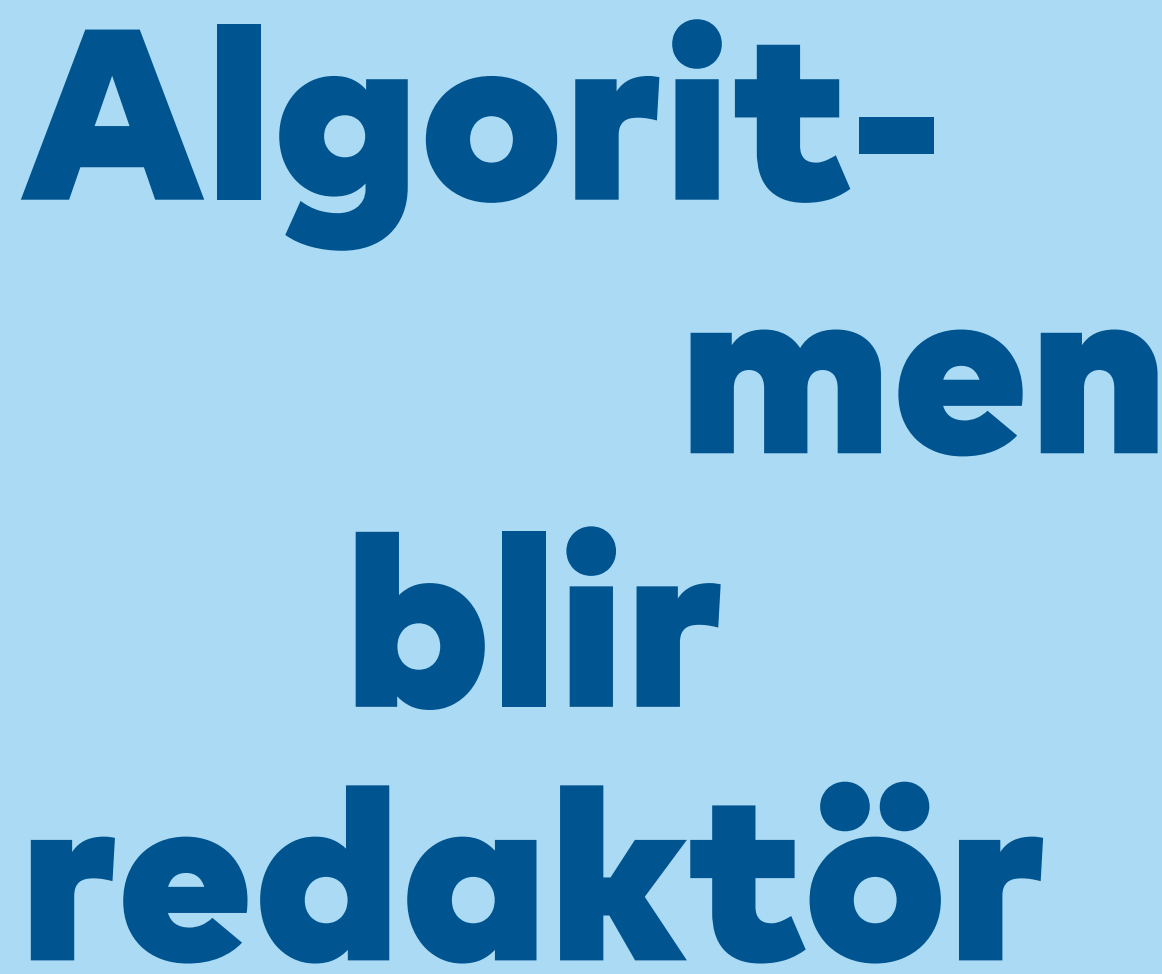

När Facebook, Google och andra digitala mediejättar uttalar sig om sina publiceringar brukar man hänvisa till "algoritmen", den mjukvara som avgör vad som visas i nyhetsflöden och sökresultat ...

Av Per Strömbäck (Sverige) 
Per Strömbäck.

Foto: Sofia Runarsdotter. Illustration: Ole Rode Jensen.

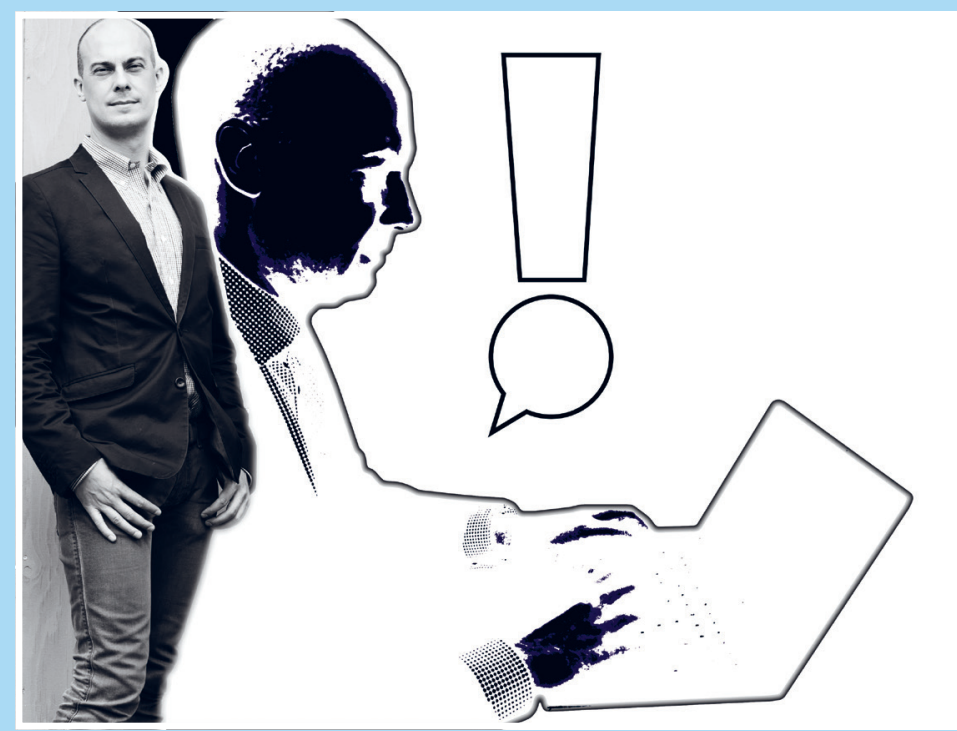

När den norske författaren Tom Egeland hösten 2016 publicerade Nick Uts världsberömda bild av den nakna flickan Kim Phuc som flyr från napalmbomber i Vietnamkriget, raderades den först av Facebooks administratörer med anledning av att nakenbilder inte är tillåtna. Dessutom stängde Facebook av Egelands konto.

Efter omfattande protester ändrade Facebook sitt beslut. Det var bra, men omvärlden fick aldrig ta del av vilka överväganden som låg bakom Facebooks vägval, än mindre möjlighet att diskutera vilka slutsatser de drog för att undvika liknande situationer i framtiden.

Facebook har inga redaktörer, deras administratörer är inte kända utanför företaget, finns ofta i något annat land och den som har synpunkter är hänvisad till de automatiska anmälningsverktyg och frågeformulär som man tillhandahåller inuti den egna tjänsten. Facebook har inte ens ett telefonnummer i Sverige.

Slutenheten är fullkomlig. När Facebook, Google och andra digitala mediejättar uttalar sig om sina publiceringar brukar man hänvisa till "algoritmen", den mjukvara som avgör vad som visas i nyhetsflöden och sökresultat. 


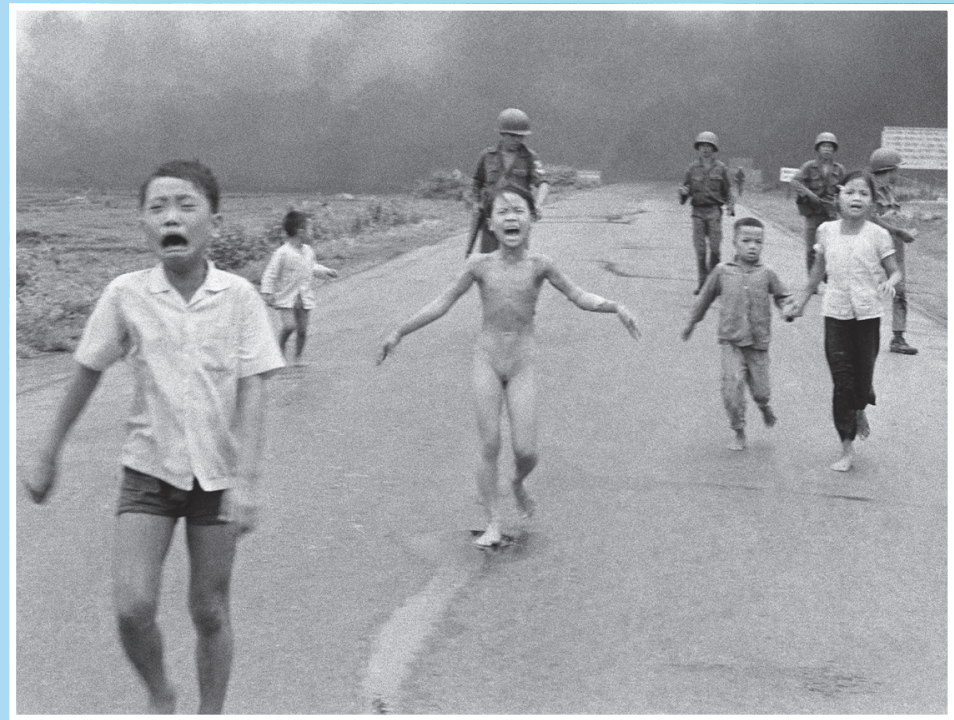

Skräckslagna barn, däribland nioåriga Kim Phuc (mitten), springer längs Väg 1 vid Trang Bang följda av sydvietnamesiska soldater efter en napalmbombning mot misstänkta nordvietnamesiska gömställen den 8 juni 1972. Foto: Nick Ut/ AP/Polfoto.

Algoritmen i sig är inte oväntat en affärshemlighet. Även på den punkten är slutenheten total.

\section{Ansvarslöshetens triumf: Teknik som ideologi}

Det råder ingen brist på röster som i tvärsäkra ordalag förklarar hur den digitala tekniken kör ifrån dagens lagar, ställer etablerade strukturer på ända och skapar nya villkor.

"Digitaliseringen är som en tidvattenvåg, den går inte att stoppa" - ett exempel, taget från en dataspelskonferens jag besökte för några år sedan.

Digital teknik som en drivkraft för samhällsutvecklingen, med en egen vilja, närmast ett högre väsen vars önskningar vi har att lyda och inte ifrågasätta.
Jag undrar om jag borde offra en get för att blidka digitaliseringens gud, hellre än att skriva debattinlägg.

Med den här tekniksynen är det rimligt att göra topplistor över vilka länder som är bäst på digitalisering och politiska förslag om avreglering för att skynda på utvecklingen. Utvecklingen är oundviklig, det bästa vi kan göra ett omfamna och skynda på den. Tvivlare, stig åt sidan!

Är framtiden alltså redan avgjord? Kan den som är tillräckligt smart redan nu lista ut vad som kommer att hända? För den som blickar bakåt kan historien te sig som förutbestämd, en sak leder till nästa.

Med en sådan materialistisk historiesyn följer framtiden på ett förutsägbart vis. Tekniken är inte resultatet av mänskliga ansträngningar, samhälleliga 
investeringar eller tillfälligheter, den följer ett förutsägbart mönster, lyder den tanken. Nöden är inte alla uppfinningars moder, uppfinningarna är redan bestämda och väntar på rätt tillfälle att förverkligas.

\section{Moores (natur)lag}

Den här deterministiska tekniksynen förstärks av ett fenomen som kallas Moores lag. Det har knappast undgått någon att digital teknik ständigt blir bättre och billigare. Principen för den utvecklingen formulerades 1965 av Gordon E. Moore, en av grundarna till processorföretaget Intel: antalet transistorer som får plats på ett kretskort med en viss yta fördubblas vartannat år. Det betyder att datorkraften fördubblas eller att priset för samma kapacitet halveras.

Om man tolkar Moores lag dogmatiskt är det bara en tidsfråga innan datorernas intelligens överträffar människans.

Den som läser ordet "lag" som naturlag hamnar oundvikligen i den tekniska determinismens resonemang. En alternativ tolkning vore att se Moores lag som observation, gissning och inspirationskälla för kretskortsutvecklare.

Men är dagens teknik resultatet av naturlagar, förutbestämda utvecklingslinjer och historiematerialistisk nödvändighet, frikopplad från mänskliga beslut?

\section{Vem äger internet?}

Det kommersiella internet som vi känner idag, med privata telebolag som säljer abonnemang och äger infrastrukturen är ett sentida fenomen. Fram till nittiotalet var det olika offentliga institutioner och universitet som stod för internets drift.

Än idag ägs stora delar av infrastrukturen av det gemensamma: i Sverige är många stadsnät kommunalägda och statliga aktörer som Trafikverket, Teracom och Svenska Kraftnät ansvarar för stora delar av de rikstäckande telenäten. Den största nätägaren i Sverige är Telias dotterbolag Skanova - Telia ägs till knappt $40 \%$ av svenska staten.

Det offentliga inflytandet över den digitala infrastrukturen är alltså betydande. Liknande situation finns i de flesta länder i Europa och även andra delar av världen.

\section{Plan för digital dominans}

Det kan tyckas som att beskrivningen av tekniken som naturkraft snarare är retorik. Eller ska vi kalla det ideologi? För den som driver digitala tjänster är det en tacksam ideologi, den ger möjlighet undvika ansvar men ändå tjäna pengar.

På så vis kan Facebook vara en global nyhetstjänst utan ansvarig utgivare, Google en förment neutral informationskälla, Uber se sig själv som en app istället för ett transportföretag, teleoperatörer kan sälja abonnemang 
med löften om gratis film och musik utan att bekymra sig om upphovsmännens ersättning - deras gemensamma självbild är att de är "teknikföretag", underförstått att de inte ansvarar för själva innehållet.

Det är inte någon slump, utan en medveten strategi. Den formulerades närmare bestämt vid Stanford-universitetet i kaliforniska Palo Alto på åttiotalet. Peter Thiel - senare notorisk riskkapitalist med investeringar i bland annat Paypal och Facebook - startade studenttidningen The Stanford Review 1987 och formulerade i en ledare fyra punkter för hur Silicon Valley skulle kunna dominera den digitala världen:

- $\quad$ ingen skatt

- ingen stat

- $\quad$ ingen copyright

- $\quad$ ingen konkurrens.

Det är lätt att läsa det som ett recept för dagens nätjättar som Amazon, Facebook, Google och Uber (möjligen platsar även Apple och Microsoft på den listan, men den förra är mer av ett hårdvaruföretag och båda har äldre rötter).

Ansvarsfriheten är också lagstadgad. 1998 lade Clinton-administrationen fram sin Digital Millennium Copyright Act som gav omfattande ansvarsfrihet för internetleverantörer.

Den europeiska motsvarigheten blev E-handelsdirektivet som antogs år 2000 och den svenska lagen om elektronisk kommunikation (LEK) från 2003. Reglerna innehåller bland annat generellt förbud mot övervakning av abonnenterna och ansvarsfrihet för teleoperatören gentemot tredje part.

Detta rör alltså själva trafiken i ledningarna, men principen om ansvarsfrihet - ofta kallad "safe harbour" - har i praktiken sträckts ut till att även omfatta tjänster som bygger på infrastrukturen. På så vis kan Uber hänvisa alla ansvarsfrågor till de förare som använder tjänsten och Facebook ducka för redaktionellt ansvar för desinformation och hot som användarna sprider. Man är ju bara en mellanhand!

\section{Faktaresistens, falska nyheter och filterbubblor}

Ansvarsfriheten, eller kanske hellre ansvarslösheten, får inte bara ekonomiska konsekvenser. Vintern 2016/17 har präglats av debatt om faktaresistens, falska nyheter och filterbubblor.

Faktaresistens är tanken att sanningen är relativ, min uppfattning är lika riktig som din och det finns så mycket desinformation som inget går ändå att lita på.

Falska nyheter är medveten desinformation, antingen med politiska motiv som i fallet med att ryska intressen skulle ha påverkat den amerikanska presidentvalsdebatten eller när högerextremister sprider osanningar om invandrares brottslighet, men det kan också vara ren business som exemplet 


\section{Otaliga är de utredningar som under- sökt ämnen som public service, nämnda presstöd, utgivaransvar, moms och reklamskatt. Nyckel- orden är ansvar och transparens. Kontrasten mot de nya medieföre- tagens ansvarslöshet är fullkomlig.}

med den makedoniska nyhetssajten Meta som med ren dikt och skicklig rubriksättning tjänat annonspengar i samma presidentvalsdebatt.

Filterbubblor slutligen är fenomenet att sociala medier och sökmotorer anpassar innehållet efter vad användaren tidigare klickat på, så vad jag får se är annorlunda än det du ser trots att vi använder samma tjänster. Det anses bekräfta våra befintliga uppfattningar snarare än att ge oss perspektiv och skapa parallellt existerande grupper med skilda världsbilder som inte möts.

Gemensamt för dessa fenomen är att de är konsekvenser av internettjänsternas sätt att fungera, ansvarsfrihetsreglerna och hur tekniken är utformad. Det är dessa företags beslut som lett hit.

Lögn, förnekelse och grupptänkande är givetvis djupt mänskliga drag som funnits i alla tider. Skillnaden är att de digitala offentligheterna förstärker dem, medan de flesta föregående system strävat efter att minimera dem genom olika ansvarsfunktioner och kontrollmekanismer såsom ansvarigutgivarskap, pressetiska regler, transparens och utbildade redaktörer.

I kölvattnet av dessa debatter har förvisso några av dessa internettjänster föreslagit vissa åtgärder för att $t$. ex. markera osanna nyheter, men $\mathrm{i}$ allt väsentligt har diskussionen handlat om att t. ex. skolan och olika myndigheter bättre borde utbilda allmänheten i källkritik och att hot och hat borde straffas hårdare.

Ansvaret skulle alltså falla på samhället och de enskilda, snarare än den som driver systemet och styr över dess utformning.

\section{Den neutrala mellanhanden}

Är ansvarslösheten det enda sättet att bygga en framgångsrik digital affär?

En tanke vore att det är marknadens funktion som tvingar fram 
ansvarslösa nätaktörer. Om de inte agerade sålunda, skulle de strax bli utkonkurrerade skulle resonemanget kunna lyda.

Men det finns andra exempel. Jag hade tillfälle att tala med Europa-chefen för ett stort dataspelsföretag och han beskrev hur de såg på sin digitala handelsplats. Deras strategi var att skapa en trygg och säker plats för både kunder och säljare där det är viktigt med en bra affär för alla inblandade. Den visionen är långt ifrån självbilden av en mellanhand utan ansvar för innehållet.

Därtill tycks det finnas gränser även för de mest liberala mellanhänderna, Youtube innehåller ingen pornografi, Facebook tar som nämnts regelmässigt bort nakenbilder och i princip alla internetleverantörer spärrar webbsidor som innehåller barnporr.

Samma internetleverantörer stryper för övrigt bandbredden för kostsam trafik som när stora filer färdas i tredjeparts nät och skapar kostnader och för tjänster som Skype som konkurrerar med deras egna telefonitjänster.

Den neutrala mellanhanden är inte mer neutral än att den ingriper mot trafik och innehåll som stör självbild eller affärsintresse.

\section{Ansvar kontra ansvarslöshet}

Etablerade medier har haft många år på sig att utveckla metoder och strukturer för att hantera de här frågorna.
Yttrandefriheten är aldrig oinskränkt: hat, hot och hets är olagligt överallt.

Redaktioner gör noggranna överväganden i samband med publiceringar. Medieföretag är medlemmar i självregleringsorganisationer. Ansvariga utgivare redogör offentligt för sina resonemang vid kontroversiella eller svåra fall.

Pressetiken har fastslagna principer och är föremål för ständig omprövning.

Journalister brukar ha flera års utbildning och ansvariga utgivare ofta många års publicistisk erfarenhet. Akademisk forskning i ämnen som journalistik och medievetenskap granskar de längre utvecklingslinjerna, regelverkens utformning, ägarskapets betydelse och mycket annat.

Även inom politiken är debatten om mediernas makt och ansvar intensiv. Kulturbudgetens presstöd syftar till mångfald genom att stödja medier med svag marknadsposition.

Otaliga är de utredningar som undersökt ämnen som public service, nämnda presstöd, utgivaransvar, moms och reklamskatt. Nyckelorden är ansvar och transparens.

Kontrasten mot de nya medieföretagens ansvarslöshet är fullkomlig. Det samma gäller transparensen: anonyma administratörer och hemliga algoritmer fattar publiceringsbesluten.

Sammantaget är det en perfekt storm som får konsekvenser för samhället, både ekonomiska och demo- 
kratiska. Det finns inget som tvingar nätjättarna att agera på det viset. Det är helt deras eget beslut.

Hur var det nu? Ingen skatt. Ingen stat. Ingen copyright. Ingen konkurrens.
Per Strömbäck är författare till flera böcker om digital ekonomi, filosofi och politik. Den senaste, 21 Digital Myths Reality Distortion Antidote (8tto 2016) är hans första på engelska. Utöver sitt författarskap arbetar Per Strömbäck för branschorganisationer inom dataspel, film och TV samt som redaktör för det Bryssel-baserade webbmagasinet Netopia - Forum for the digital society (www.netopia.eu).

\section{Algorithm as editors}

\section{$4 \pi$}

By Per Strömbäck (Sweden)

Per Strömbäck is editor for the web magazine netopia.eu and author of several books on digital economy.

We are facing a new reality for media, where i.e. facebook allows algorithm as the new editors to design our newsroom.

Digital technology masquerades as inevitability, but rather the lack of responsibility and transparency in the new media companies. It is a product of self-interest and choice, pushed by legislation and government investment.

There is nothing inevitable about today's situation, argued by the author drawing and analysing upon technological development and legislation to support his case. While the lack of responsibility on the part of Internet intermediaries may be healthy for their profits and the stock portfolios of their share-holders, the rest of society pays the price.

The free services we enjoy may not only threaten our privacy, but the worst is that truth, our democracy and legal foundation are at risk. Using the cover of being "only a technology company", Internet companies can turn a blind eye to the consequences of user behaviours and further impact on society as a whole. If "information wants to be free" was an appealing maxim in the early days of the world wide web, maybe traditional media hold the answer to how we can make online environment a better place. 

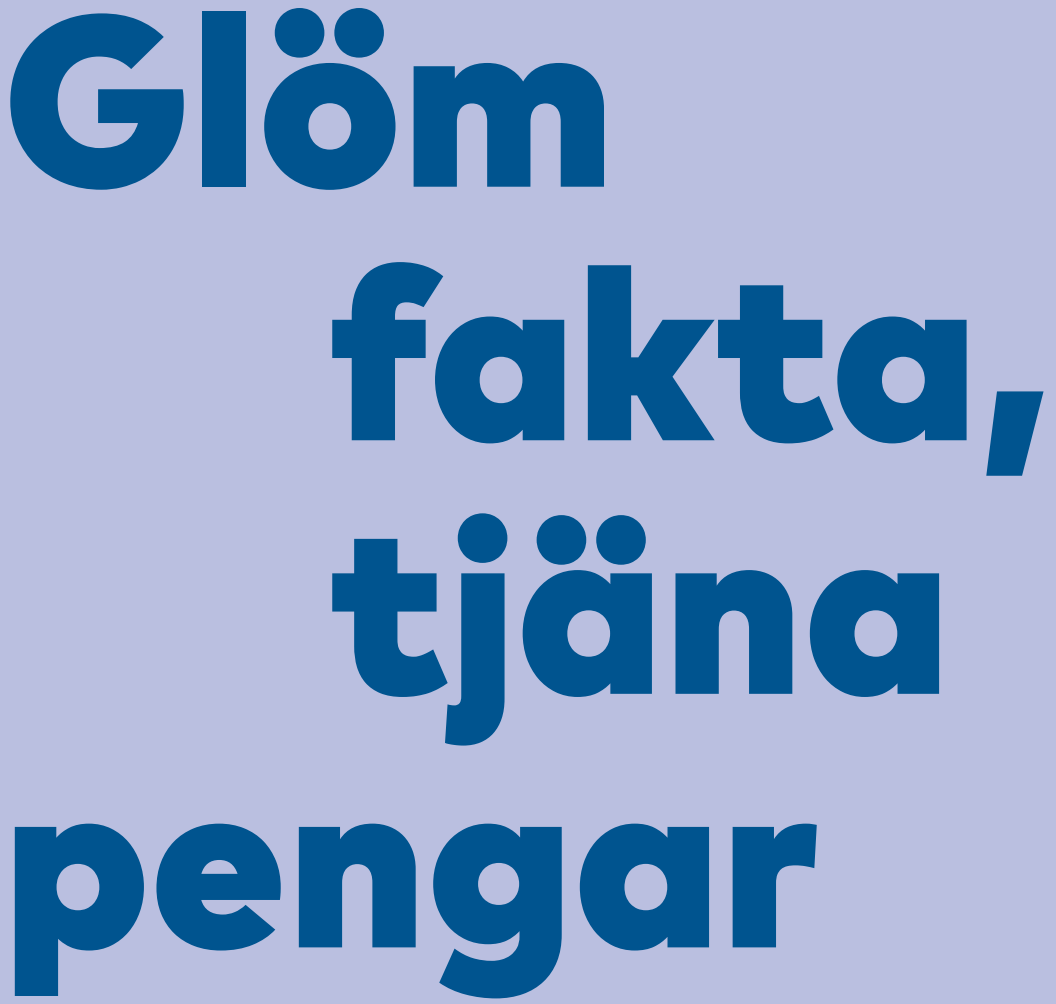

Fake news is business. Ju mer falsk desto fler läsare. Och desto mer pengar. Att välja vilka falska nyheter som ska distribueras har ingenting att göra med politiska åsikter ...

Av Heikki Jokinen (Finland) 
Heikki Jokinen. Foto: Riitta Supperi/ Keksi. Illustration: Ole Rode Jensen.

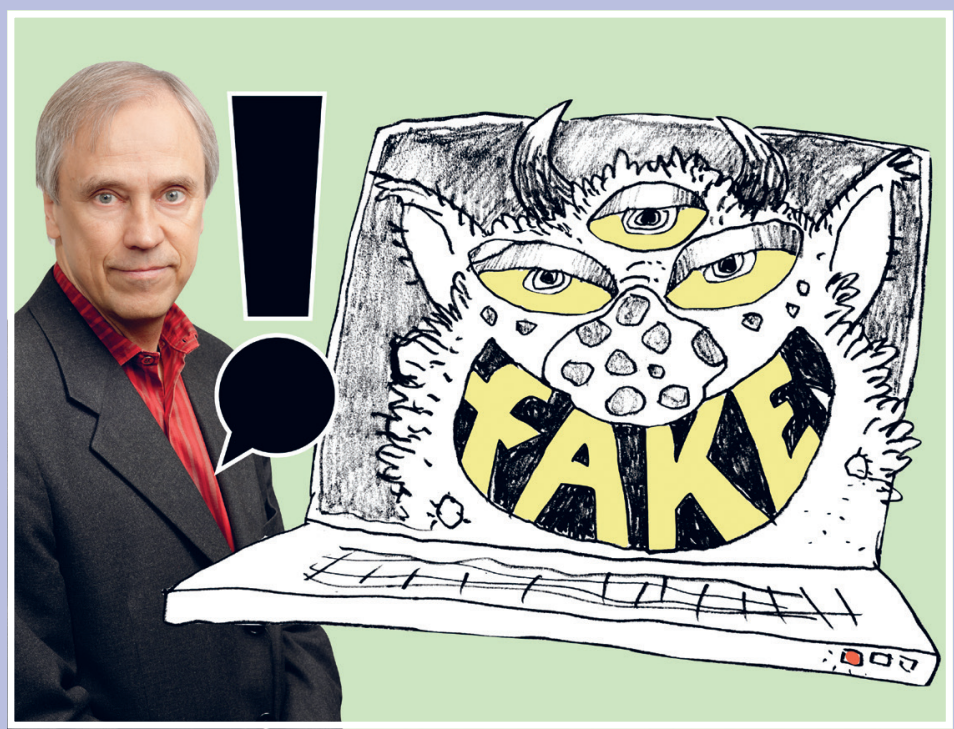

Visste du, att muslimska asylsökande har skändat den kristliga världen genom att bajsa och urinera i Heliga Trefaldighetskyrkan i Kristianstad i Skåne? Samt att skriva islamistiska slogans på kyrkans väggar? Inte? Men miljoner har hört vad som hände och tusentals har blivit riktig arga, särskilt i USA.

Men det vet du säkert, att en pizzeria i Washington DC hade en pedofilring i källaren och att Hillary Clinton var inblandad i den? Det visste och trodde ju en stor del av USA:s medborgare.
Förra december gick en av dem själv till pizzerian med vapen i handen för att göra slut på pedofilernas smutsiga sysslor - som han visste skyddades av Washingtons elit.

Resten av de arga människorna nöjde sig med att skicka en varning till restaurangens ägare. "Denna restaurang skall brännas ner till grunden", stod på en av de tiotals meddelanden han fick.

\section{Money makes the}

\section{world go around}

Inte överraskande: Pengar ligger bakom dessa helt och hållet påhittade falska nyheter. Företag som Facebook och Google tjänar sina pengar med att 


\section{Amerikaner älskar våra historier och vi gör pengar på dem. Vem bryr sig om de är sanna eller falska?}

folk klickar på annonser på deras sidor. Ju fler läsare, desto mera annonser och desto mera klick. Detsamma gäller förstås för olika mer eller mindre seriösa nyhetssidor på nätet.

Vi människor är ju sådana att vi vill bli arga för saker vi inte tycker om. Säger rubriken på Facebook-strömmen nånting chockerande om saken eller människan vi älskar att hata, blir det lätt att klicka. Och precis sådana poster har Facebooks algoritm lärt sig att visa oss för Facebook tycker om snabba reaktioner och stora känslor.

De mest chockerande rubriker som ska få oss att klicka skriver de som inte behöver bry sig ett dugg om sanningen eller journalismens etiska regler. Fakta har förstört många goda nyheter, det vet den journalistiska folkloren.

\section{Lokala nyheter från Makedonien}

Det finns också ett annat sätt att tjäna pengar med helt och hållet upphittade nyheter. Många tidningar även här i Norden har skrivit om de unga i den makedoniska småstaden Veles. De hade hittat en fin business: att producera och, på sina nätsidor, distribuera falska nyheter till läsare i USA.

Då läsare klickar på annonser på deras sidor, kommer pengar in. Inte alla gör det, men tillräckligt många för att skapa inkomst.

Med en hög ungdomsarbetslöshet och en genomsnittlig lön på några hundra euro per månad är det lätt att förstå hur produktion och distribuering av falska nyhetssidor blev en populär syssla i Veles.

Före förra presidentvalet i USA registrerades $i$ Veles, enligt tidningen The Guardian, över 150 domäner som för det mesta hade ett pålitligt klingande namn och handlade om politik i USA. En del av dessa hävdar att de har miljoner av besökare. De flesta gav ut sensationella falska nyheter om politik och val i Förenta Staterna.

Via Facebook fick dessa massiv synlighet och läsarskara. För att stödja synlighet skapade och köpte man falska Facebookprofiler. Enligt tidskriften Wired, som har intervjuat dessa nätsidors skapare i Makedonien, kostade en förfalskad Facebookprofil med ett ryskt namn 10 US-cent att köpa, med ett amerikanskt namn 50 US-cent. 
BBC intervjuade Goran, en 19-årig student från Veles. "Amerikaner älskar våra historier och vi gör pengar på dem. Vem bryr sig om de är sanna eller falska?", säger han.

\section{Klippa och klistra}

Innehållet för sina politiska sidor kopierade makedoniska unga för det mesta från ultra-högersidor från USA. De lade till en sensationell rubrik och distribuerade historien. Några makedoniska nätsidor betalade skribenter från USA för att utforma nyheter som var ännu mera sensationella.

Att välja vilka falska nyheter som ska distribueras har ingenting att göra med politiska åsikter hos dem som driver dessa nyhetssidor i Makedonien. Enligt Buzzfeeds artikel prövade de också sensationella nyhetssidor som lutade åt vänster eller stödde Bernie Sanders.

De sålde inte. Sanders eller Clinton anhängare hade rätt begränsat intresse att läsa dessa. Man lärde sig snabbt att ju mer falsk och höger, desto fler läsare. Och desto mer pengar.

Enligt Buzzfeed samlade den mest populära falska nyheten om Hillary Clinton från Makedonien 480000 delningar, reaktioner och kommentarer på Facebook. Siffran går att jämföra med de 175 ooo Facebookinteraktioner för New York Times nyhet om Donald Trumps förlust på 916 miljoner US-dollar i beskattningen av 1995.

\section{"I går kväll i Sverige"}

Vi i Norden står inte utanför den stora världen. Makedoniska nätsidor var inte bara inblandad i den ovannämda falska nyheten om pedofilerna i en pizzeria $\mathrm{i}$ Washington DC, utan också i den om kyrkan i Kristianstad.

Dagens Nyheter har spårat hur nyheten om Kristianstad gjorde tusentals människor i USA arga och skapade islamfientliga kommentarer. Tidningen intervjuade Ivan Stankovic i Makedonien. Han ger ut en nyhetsida på Facebook med 200 ooo följare.

\section{Narkomaner i kyrkan är ju inte så spännande direkt. De har väl ändrat det till muslimer för att artikeln ska bli mer populär, helt enkelt.}


Historien om kyrkan hittade han på en islamfientlig ultra-höger nätsida från USA. Dit hade den kommit från en svensk högerriktad nätsida, men den hade skrivits om rejält.

Bakom den falska nyheten finns nämligen en sann historia. I Kristianstadskyrkan hade det varit problem med alkohol- och narkotikaanvändare som stökat, som media i Sverige berättade om. Som numera är så vanligt, började det omedelbart en hektisk debatt på nätet om att de var asylsökande.

Den amerikanska nätsidan tog historien men skrev om den så att alkoholoch narkotikaanvändare blev muslimer. Ivan Stankovic såg genast att nyheten var falsk, men den hade snabbt fått många delningar och gillanden. Den hade alltså potential att få många klick, så han lade den till alla sina nätsidor. Och fick många klick.

"Narkomaner i kyrkan är ju inte så spännande direkt. De har väl ändrat det till muslimer för att artikeln ska bli mer populär, helt enkelt", säger han till Dagens Nyheter om den amerikanska nätsidans sätt att skriva om nyheten.

\section{En hel månadslön på "förbjudna jullyktor"}

Efter denna behandling fick historien vingar och blev publicerad i många länder och på många nätsidor. Snart var den uppe på sidor med sammanlagt över 10 miljoner följare.
Efter denna och många andra liknande falska historier påstår sig miljoner människor utanför Sverige veta vad som hände "last night in Sweden".

Stankovic berättar också för Dagens Nyheter om sin största succé. Han gav ut en falsk nyhet att myndigheterna har förbjudit jullyktor i Sverige för att inte förolämpa muslimska invandrare.

"Det blev helt galet, säger Ivan. Jag fick in en hel månadslön på en dag, jag hade aldrig förut tjänat så mycket på en enda artikel", säger han till tidningen.

\section{Framgångens avigsida}

Vad har allt detta att göra med journalismen? Tyvärr ingenting vad gäller journalisternas sätt att arbeta, etiska regler och strävan att gräva fram fakta. Men tyvärr minst lika mycket att göra med journalistikens framtid och ekonomi.

Kan det hända att sådana helt och hållet upphittade så kallade nyheter småningom kommer att ersätta journalistiken, eller i alla fall en del av den? Blir yttrandefrihet nånting för bara de mest sensationella, effektiva och stora aktörer? Det är inte gratis att granska fakta och bedriva sakkunnig journalistik.

Facebook är en genial uppfinning. Den ger människor helt nya möjligheter att skapa och upprätthålla kontakter med andra människor. Den ger människor en känsla av att höra till gruppen, öppnar nya portar. Den sprider effektivt information. 


\section{Yttrandefrihet är inte bara rätt att säga vad som helst. Det är också rätt att få mångsidig information som strävar efter att baseras på fakta och korrigerar sina fel.}

Men den är en business, en bra business dessutom. Under det sista kvartalet av 2016 hade Facebook 1,23 miljarder dagliga användare. Under samma tre månader samlade den in 8,629 miljarder US-dollar i reklamintäkter. Det blir sju dollar per daglig användare.

Facebook har de facto blivit världens största media, trots att den inte producerar något innehåll själv.

Denna framgång har också sin avigsida. De medier som satsar på att gräva fram relevant information och granska fakta har stora ekonomiska svårigheter. Delvis beror det på att reklamintäkterna går ner och delvis på att läsarna blir färre.

\section{Journalistisk etik är inte död}

Det vore alltför enkelt och också fel att skylla allt på nätet. Etablerade tidningar var dåligt förberedda för den revolution som nätet gjorde i vårt liv. Att pengarna rullade in var alltför självklart.

Finlands Journalistförbunds tidskrift Journalisti räknade för några år sedan ihop affärsvinsten för de fem stora tidningskoncern och en stor tidskrifts- koncern i Finland mellan år 2006 - 2011. Den genomsnittliga affärsvinsten var mellan 11 och 15,87 procent. På toppen var llkka-koncernen med 35,2 procent i affärsvinst 2011.

Dessa dagar är förbi, trots att vi de senaste veckor har hört lite bättre nyheter om mediernas ekonomiska situation. Ändå, just nu kämpar många tidningar och tidskrifter för sitt liv.

Det är naturligtvis inte nödvändigt att vi har samma medier som nu i framtiden, de är också business som har sin tid att leva och dö. Men det som är viktigt är att vi överhuvudtaget har medier och journalister som följer journalistiska etiken.

"Det är journalisters plikt att sträva efter en sanningsenlig informationsförmedling" säger journalistreglerna i Finland. Det är viktigt att inte upprepa falska nyheter: "Journalister bör kontrollera uppgifter så väl som möjligt även om de har publicerats tidigare."

"Allmänheten ska kunna skilja fakta från åsikter och fiktivt material" och "Journalister ska förhålla sig kritiskt till informationskällorna". 
Yttrandefrihet är inte bara rätt att säga vad som helst. Det är också rätt att få mångsidig information som strävar efter att baseras på fakta och korrigerar sina fel.

\section{Återvinning som lösning}

Den etablerade media är inte alls en enhet, där alla delar är likadana. Tidningar betonar olika saker och nyheter. I vissa fall har de även en linje som syns, som med debatten om ett möjligt Natomedlemskap i Finland. En del tidningar ger mera plats för texter som är i regel positiva för Nato, även om själva nyheterna är skrivna enligt journalistiska regler.

Därför är mångsidig information och media ytterst viktigt.

Tidningar bidrar dessvärre också till att gräva en grop för sig själva. Det känns som om några utgivare har givit upp. I jakten för att minska kostnader har man i vissa fall även kastat bort sådant som kunde vara tidningens starkaste sida: lokalt förankring och trogna läsare.

I och med att ekonomin för kommersiella medier har blivit svårare är det ännu viktigare att se vad som händer med public servicekanaler i tv och radio. De är inte beroende av reklamintäkterna och - i princip - ägarnas möjliga intressen för innehållet.

Tyvärr finns numera ett politiskt tryck att minska public service budget eller begränsa deras journalistiska bevakningsområde. Trycket skulle vara motsatt: att garantera public service resurser och möjlighet att driva oberoende journalistik.

\section{Blir vi mänskliga algoritmer?}

Vi journalister måste också se upp bättre med vad vi gör. Det blir farligt om vi börjar göra vårt jobb som en slags mänsklig algoritm, sökande nånting som så många som möjligt gillar och klickar och med att försöka klara i konkurrens med falska nyhetsrubriker.

Sådant händer redan nu. På några redaktioner jagar man klick med fantasifulla rubriker. Tidigare lärde sig journalisterna att skriva in i rubriken eller senast i ingressen vad nyheten handlar om. Nu skall det ofta utelämnas på nättidningar för att få läsare att klicka på texten - bara för att överhuvudtaget veta vad är det frågan om.

På några medier den nya modellen att betala till frilansjournalister är baserad på hur många gånger deras texter blir öppnade på nätet. Då skall journalisten använda mera energi för att göra texten lockande än att gräva fram ännu mera ny information för sin artikel.

Vad bör göras? Som en vanlig mediekonsument är det värt att ha mångsidiga medievanor. Man skall spräcka den bubbla där internetjättarnas algoritmer låser in en.

Man skall följa allt möjligt: olika tidningar, åsikter, tidskrifter, nätets 
nyhetsidor och även böcker. Och inte glömma public service-radio och $\mathrm{tv}$, deras journalistik är fri från det kommersiella trycket - så länge de får de resurser som behövs.

Till sist den svåraste saken: genom att betala åtminstone lite för vår media försäkrar vi oss om att den ambitiösa journalistiken har en framtid. Rösta med dina pengar, inte bara med ditt pekfinger på telefonskärmen.

\section{Fake news make money}

By Heikki Jokinen (Finland)

Heikki Jokinen is a freelance journalist and vice chairman of the board of the Finnish Union of Journalists.

Did you know that Muslim refugees desecrated a church in Kristianstad, Sweden with broken liquor bottles, urine and faeces? True or False? But millions of people read about it.

The story is not true at all, but this kind of fake news are connected with one thing: money.

These stories make money for the web sites that publish them. The more shocking the headlines and claims ae, the more clicks, ads and income they generate.

There is also another way to make money out of completely imaginary news.
Annars är vi utelämnade på nåd och onåd åt makedonska tonåringarnas businessidéer och de amerikanska internetjättarnas vinstsökning.

Heikki Jokinen är magister i samhällsvetenskap och frilansjournalist sedan 1986. Han är vice ordförande i styrelsen för Finlands Journalistförbund.

In a small Macedonian city called Veles many people produce fake news as a living. The fake news mainly target at the U.S. market to attract a maximum number of clicks. The story on Muslim refugees is one of the stories widely distributed by the websites.

Meanwhile, the economic model of traditional media is faling. Because fact-checking, ethical and investigative journalism are not cheap.

Will false news slowly take over the quality journalism? Can journalists still do their job?

What is to be done? Everyone can help by supporting diverse and balanced media and paying for their media consumption. 
The challenge

in an era of

misinformation

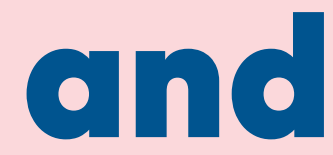

disinformation

The concept of freedom of

expression in Europe is based

on the history of a continent

which was devastated after

two world wars.

By Elfa Ýr Gylfadóttir (Iceland) 
Elfa Ýr Gylfadóttir. Photo: Mogens Blicher Bjerregård. Illustration: Ole Rode Jensen.

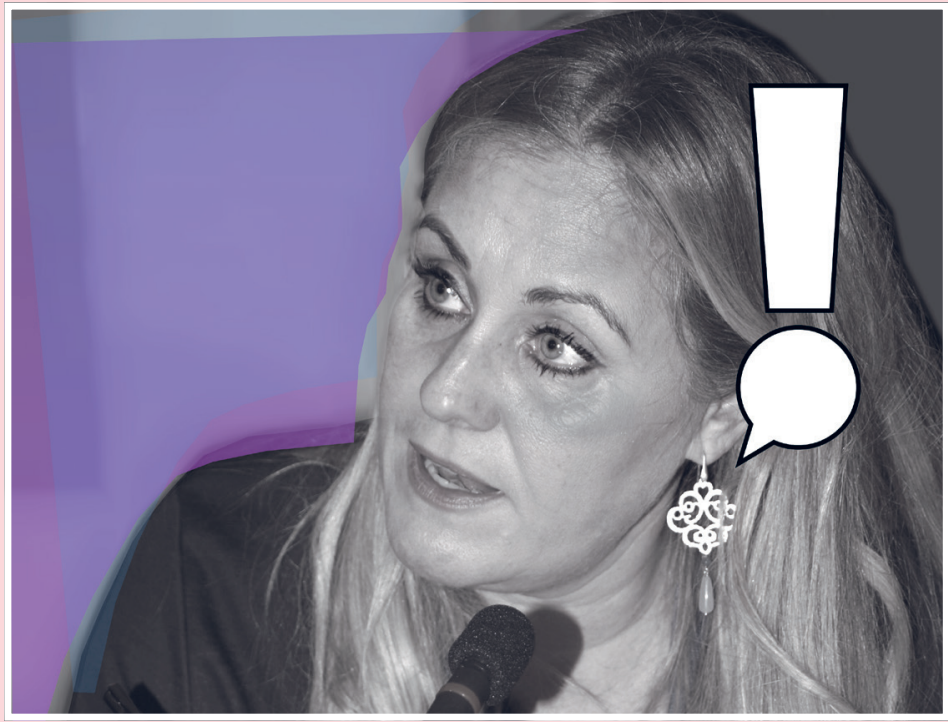

\section{Europeans believe that cer- tain expressions can be so harmful that there is a need for restriction.}

Knowledge is only a mouse-click away for the majority of the general public. The human kind has never had such access to information as with modern communication technology. The general public can both find and disseminate information in an easy and accessible way. Even though this technology provides us with many advantages and opportunities, there are also serious challenges.
As frequently reported in the media, the information is not all true, accurate, objective and impartial. It has even been said that despite the easy access to knowledge, we as a human kind, are now living in the era of misinformation or disinformation. Oxford Dictionaries even selected the word "post-truth" as 2016's international word of the year.

Information can be misleading or influenced by certain beliefs; it can contain incorrect assumptions that are based on misleading facts (misinformation). In other cases, information is fundamentally false (disinformation). In both instances, it might be in the interest of those providing the information to distort and distract the general public. 


\section{The role of independent and professional journalism}

The history of the press and democracy is closely linked. It is the role of the media to educate, inform and provide a forum for democratic debate. This is the kind of media that serves the public interest and hence democracy, instead of pursuing particular interests. Democracy in any state depends on independent and professional media.

Professional journalists do not all work for private or public broadcasters, community media or the printed or electronic press. The definition of media actors has expanded as a result of new forms of media in the digital age. It is therefore important to include others who may contribute to the public debate by disseminating accurate and fair information. These actors also perform journalistic activities and fulfil the functions of public watchdog.

\section{0th Century ethical rules and standards for media}

After press freedom was secured in the Nordics as in most of Europe and the United States, the public were given the access to news and information from various sources. The diversity of sources became an important pillar for media pluralism. During the $20^{\text {th }}$ Century, ethical codes and journalistic standards were set to ensure that the media holds their responsibilities. It was considered important that media companies not only exercise their rights, but also fulfill certain responsibilities because of their power to set the news agenda and to influence the public opinions.

In Europe, self-regulatory systems were established usually by journalists. The code of ethics was meant to ensure truthfulness, accuracy, objectivity, impartiality, fairness as well as public accountability in the media. Furthermore, Press Councils as we know them in most of the Nordic countries were established as industry-wide self-regulation bodies.

National public broadcasters were established in most countries in Europe in the 1920's and 1930's. When television broadcasting began in Western Europe, they were regarded as an extension of radio and hence became the responsibility of national radio broadcasting institutions. Public service broadcasters were national institutions, operating in a national context. They shared a similar ideology and were usually owned by the state. But they differed from each other in terms of structure and cultural characteristics.

\section{Public service broadcasters being used for propaganda}

During the World War II, public service media had a different role, depending on the position of the country during the war. Propaganda during the WWII included both misinformation and disinformation in a large scale and some 
public broadcasters in Europe were used for propaganda purposes.

Having learned from the lesson during the war, it became obvious that high ethical standards and accountability in public service broadcasters and the press pave for the foundation of independent and democratic media.

This model survived in the Nordic Countries and Western Europe until satellite television was introduced to the general public during the last decades of the $20^{\text {th }}$ Century, the monopoly of the public service broadcasters was also abolished. However, that did not diminish the cultural and democratic role of public service broadcasters. They are still considered to be of most important for a diverse media landscape, contributing to cultural diversity and social cohesion.

A number of commercial broadcasters emerged in the 1980s adding to the pluralism of content and diversity in the media. However, they also have to follow principles, in many ways similar to the public service broadcasters. In most cases, it became the role of the media regulators to ensure that these principles were followed by commercial broadcasters.

\section{Media in the United States}

Media has for historical reasons developed differently in the United States than that in Europe. Private commercial radio and television networks were established and clear obligations were imposed on them until the end of the last century.

Before passing the Communications Act of 1934, a debate took place whether to include public service media in the U.S. with the purpose of educating and informing the general public with certain objectives in mind. When the Act was passed, the commercial networks were put in the forefront at the expense of public service broadcasters.

Decades later, a law was passed to establish the role of public service media. When president Lyndon B. Johnson signed the Broadcasting Act in 1967, he described its purpose as:

"It announces to the world that our nation wants more than just material wealth; our nation wants more than a 'chicken in every pot.' We in America have an appetite for excellence, too. While we work every day to produce new goods and to create new wealth, we want most of all to enrich man's spirit. That is the purpose of this act."

\section{Public service media marginalised}

However, the law put real constrains on public service broadcasters, which left them little room for manoeuvre. Thus, they never became a real competition to the commercial networks, resulting in the fact that they became marginalised. 


\section{It is the role of the media to \\ educate, inform and provide a \\ forum for democratic debate ... \\ Democracy in any state depends \\ on independent and professional \\ media.}

Public service broadcasters became almost entirely decentralized instead of and operated by the government although they received some government support. More importantly, public service broadcasters in the U.S. never got the resources and the budget to compete with commercial media, resulting in low audience share and marginal impact in public debate.

It is heavily debated in the United States whether the deregulation of the broadcasting market and the abolishment of the fairness doctrine created opportunities for more biased broadcasting. Whatever the reason is, conservative and progressive radio talks and more biased news programmes started to emerge in the U.S. market at the end of $20^{\text {th }}$ Century. News broadcasters in the United States can be inaccurate and both editorially and ideologically biased. Regulatory requirement for accuracy and impartiality is very limited.
It is also important to keep in mind that although the press in the United States has followed ethical principles in journalism for decades, there has never been a wide self-regulation mechanism in place, such as the Nordic Press Councils, to enforce those principles and to hold the press accountable.

\section{Article 10 or First Amendment, between Europe and America}

Freedom of speech is ensured in the First Amendment in the United States Constitution. It is interpreted in a very different way by U.S. courts in comparison to Article 10 of the European Convention of Human Rights, which also provides the rights to freedom of expression and information. Freedom of expression according to Article 10 is subject to certain restrictions that are "in accordance with law" and "necessary in a democratic society". These restric- 
tions are outlined in the case law of the European Court of Human Rights.

Such restrictions usually include endangering national security, hate speech, protection of children and youth, and agitating for violence. Needless to say, freedom of speech in the U.S. also has certain restrictions found in the U.S. case law. However, some restrictions on freedom of expression in some European countries might be considered unconstitutional in the United States.

For the purpose of simplification, it could be argued that the concept of freedom of speech in the United States constitutes a marketplace of ideas. The marketplace of ideas holds that the truth will emerge from the competition of ideas in a free, transparent and public discourse. It concludes that ideas and ideologies will be culled according to their superiority or inferiority and widespread acceptance among the population.

\section{Painfully aware of the power of propaganda}

On the contrary, the concept of freedom of expression in Europe is based on the history of a continent which was devastated after two world wars. Europeans were unfortunately painfully aware of the power of propaganda and what certain type of expression could lead to.

From a policy standpoint, Europeans believe that certain expressions can be so harmful that there is a need for restriction. Historically, it is therefore understandable that Holocaust denial is punishable in Germany. It is also understandable for historical reasons that the dissemination of means of propaganda of Unconstitutional Organisations is prohibited as well as the use of symbols of Unconstitutional Organisations (items such as the Swastika or clothing of the socialist youth movement).

\section{From an Icelandic perspective, being at the border of Europe and America, it can be argued that Iceland has some important features taken from both systems.}




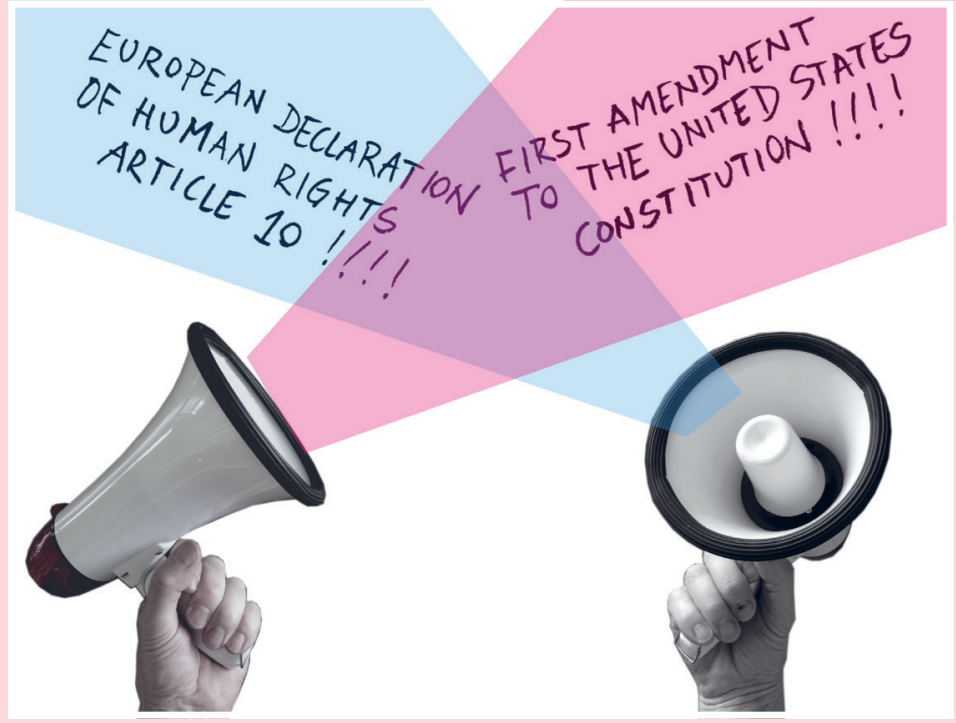

Iceland between two continents, and two concepts of freedom of expression: The First Amendment to the Unites States Constitution and Article 10 of the European Convention on Human Rights. Illustration: Ole Rode Jensen.

Regulation and accountability thus develops differently depending on the underlying ideology that nations have about the nature of the media and how people form their ideas. From an Icelandic perspective, being at the border of Europe and America, it can be argued that Iceland has some important features taken from both systems.

\section{The role and impact of social and internet media}

Can it have an impact on the global media market because of how different countries interpret freedom of expression and how they ensure the rights and responsibilities of news dissemination? Yes, it most certainly can.
Increasing number of people are getting their news from social media sites such as Facebook and Twitter. People search for news and information on platforms like Google. These companies are usually based in the United States where freedom of expression and the accountability of dissemination of news and information have historically been interpreted in a very different way than that in the Nordics. Furthermore, information and news on the Internet can spread much easier and faster than traditional media. So the questions arise are: Who can be held accountable for content in the new media market? And how can accountability be ensured? 


\section{The rhetoric of the marketplace of ideas}

It has frequently been pointed out in the Nordic media that it is in the interest of the big American companies to fight against harmful speech with counter narratives, following the rhetoric of the marketplace of ideas. This increases the traffic on their sites and generates more income.

Meanwhile, what has been called "fake news" is spreading on a global scale in an alarming speed, impacting the opinions and views of the general public. At the same time, professional media operating according to ethical journalistic principles is frequently called "Lügenpresse" (lying press). The word derives from Nazi Germany when it was used for printed press and the mass media at large.

\section{An explosion of fake fact-checking}

As a means to counter incorrect information, a number of professional media entities are operating fact-checking sites with the aim to inform the public in an accurate and impartial manner. At the same time, there has been an explosion of fake fact-checking sites. It seems that there is no end to the battle of truth vs. fake news, and preventing misinformation and disinformation from spreading on the Internet.

It does not seem like the truth is emerging from the competition of ideas in a free, transparent and public discourse. The discussion about "filter bubbles" and "echo chambers" is an evidence of such a scepticism. We are even faced with the fact that descriptive terms like "fake news" or "alternative facts" are exhausted and have lost their meaning in the public debate.

No solution has yet been found to solve the challenge. What is clear, however, is that the need for independent and professional journalism is greater than ever. Unfortunately, all members of our society do not believe that professional and independent media is accurate and impartial. This fact undermines social cohesion and the shared principles of what our society is based on.

We have to find a viable solution to this challenge. What is at stake is democracy.

Elfa Ýr Gylfadóttir is the Director of the Media Commission, the independent regulator for media in Iceland. Prior to that she was the Head of Division of Media at the Ministry of Education, Science and Culture. Elfa Ýr Gylfadóttir has been a lecturer at the University of Iceland for 15 years. She is the author and co-author of several peer reviewed articles on media policy and media law. She is the Chair of the Steering Committee on Media and Information Society at the Council of Europe. 


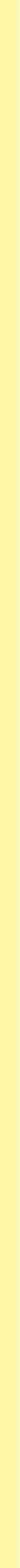





\section{$\mathbb{1 0}$}

Nordiska ministerrådet

Ved Stranden 18

DK-1061 København K

www.norden.org

Debattboken består av fjorton olika inlägg skrivna av människor som alla har intressanta åsikter om yttrandefrihet och vad som utmanar den.

Debattörerna kommer från Danmark, Finland, Island, Norge, Sverige samt Färöarna, Grönland, Åland och Sameland.

Hur väl förvaltar vi yttrandefriheten i Norden? På vilket sätt utmanas den av hatretorik, hotelser och nättroll, falska nyheter och ojämlikhet?

Vad betyder etik, ekonomi, politik och globala aktörer som Facebook och Google för den nordiska yttrandefriheten?

"Yttrandefrihet är inte bara rätt att säga vad som helst" (citat ur ett debattinlägg).

Debattboken handlar om den svåra yttrandefriheten. 